Cornell Law Library Scholarship@Cornell Law: A Digital Repository

Cornell Law Faculty Publications

$10-1-2006$

\title{
Constitutional Avoidance in the Executive Branch
}

Trevor W. Morrison

Cornell Law School, twm25@cornell.edu

Follow this and additional works at: http://scholarship.law.cornell.edu/lsrp_papers

Part of the Constitutional Law Commons

\section{Recommended Citation}

Morrison, Trevor W., "Constitutional Avoidance in the Executive Branch" (2006). Cornell Law Faculty Publications. Paper 46. http://scholarship.law.cornell.edu/lsrp_papers/46

This Article is brought to you for free and open access by Scholarship@Cornell Law: A Digital Repository. It has been accepted for inclusion in Cornell Law Faculty Publications by an authorized administrator of Scholarship@Cornell Law: A Digital Repository. For more information, please contact jmp8@cornell.edu. 


\title{
COLUMBIA LAW REVIEW
}

VOL. 106

OCTOBER 2006

NO. 6

\section{ARTICLES}

\section{CONSTITUTIONAL AVOIDANCE IN THE EXECUTIVE BRANCH}

\author{
Trevor W. Morrison*
}

When executive branch actors interpret statutes, should they use the same methods as the courts? This Article takes up the question by considering a rule frequently invoked by the courts-the canon of constitutional avoidance. In addition to being a cardinal principle of judicial statutory interpretation, the avoidance canon also appears regularly and prominently in the work of the executive branch. It has played a central role, for example, in some of the most hotly debated episodes of executive branch statutory interpretation in the "war on terror." Typically, executive invocations of avoidance are supported by citation to one or more Supreme Court cases. Yet those citations are rarely accompanied by any discussion of the values courts try to serve when they employ avoidance. Are those values specific to the federal judiciary, or do they reflect substantive commitments extending beyond the courts? Equally lacking is any sustained consideration of interpretive context. Does their particular institutional location and function enable executive actors to call upon sources of statutory meaning that are unavailable to courts, rendering rough tools like the avoidance canon unnecessary?

This Article explores executive use of the avoidance canon along both these dimensions. As to theoretical justification, Professor Morrison shows that whether constitutional avoidance is appropriate in the executive branch tums on whether one accepts the conventional account of the canon, which sees it as serving values specific to the federal judiciary, or an alternative account, which views it as serving a set of broader norms not confined to the courts. As to interpretive context, Professor Morrison shows that because executive officials often have better access to and knowledge of statutory purpose than do the courts, some facially ambiguous texts may in fact be entirely

* Associate Professor of Law, Cornell Law School. For valuable comments and suggestions, I thank Bernie Bell, Lisa Bressman, Jim Brudney, Steve Clymer, Mike Dorf, Bill Eskridge, Cynthia Farina, David Franklin, Phil Frickey, Brian Galle, Toby Heytens, Aziz Huq, Dawn Johnsen, Sheri Johnson, Doug Kysar, Marty Lederman, Ron Levin, John Manning, Jerry Mashaw, Jonathan Mitchell, Henry Monaghan, Randy Moss, Rick Pildes, Jeff Rachlinski, Ricky Revesz, Steve Shiffrin, Kevin Stack, Dave Stras, Peter Strauss, and Jay Wexler. Thanks also to participants in the 2006 Stanford/Yale Junior Faculty Forum, a panel discussion at the Fall 2005 meeting of the ABA Section on Administrative Law, and faculty workshops at Cornell Law School and Southwestern University Law School. Finally, thanks to Michael Francisco, Andrew Nieland, and Andrew Por for excellent research assistance, and to Leanne Wilson and the staff of the Columbia Law Review for patient and thoughtful editing. 
unambiguous to the executive interpreter. In those circumstances, the avoidance canon has no role to play.

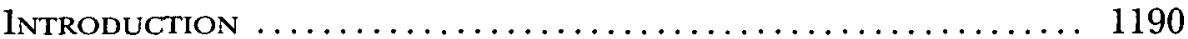

I. Framing the lssue: Statutory lnterpretation Outside THE Courts .............................. 1196

II. The Avoidance Canon in the Courts .............. 1202

A. The Conventional Theory of Modern Avoidance:

Judicial Restraint........................... 1202

B. Leading Criticisms of Modern Avoidance .......... 1208

C. An Alternative Theory of Modern Avoidance:

Constitutional Enforcement .................... 1212

III. The Avoidance Canon in the Executive Branch:

ApPlying the Theories ......................... 1217

A. The Executive's Use of Avoidance in Practice........ 1218

B. The Avoidance Theories in the Executive Branch..... 1220

C. Self-Protective Avoidance ...................... 1228

D. The Risk of Abuse ......................... 1235

E. The Need for Congressional Notification .......... 1237

IV. The Avoidance Canon in the Exfcutive Branch:

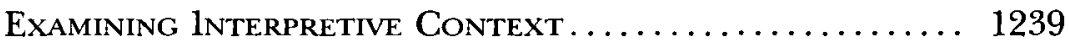

A. The Information Richness of Executive Statutory

Interpretation .......................... 1240

B. Examples of Inappropriate Avoidance ........... 1244

1. Needless Avoidance in Bill Comments by the

Office of Legal Counsel ................... 1244

2. Changing the Legislative Bargain in Presidential Signing Statements ................... 1245

3. Institutional Amnesia in Interpretations of Existing Statutes .............................. 1250

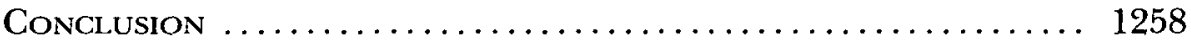

\section{INTRODUCTION}

Statutory interpretation is not the exclusive province of the courts; it is a core function of the executive branch as well. Indeed, "[i]nterpreting a law enacted by Congress to implement the legislative mandate is the very essence of 'execution' of the law." It is remarkable, then, that so Iittle scholarly attention has been paid to how executive branch actors interpret statutes, and how they should interpret them. ${ }^{2}$

1. Bowsher v. Synar, 478 U.S. 714, 733 (1986).

2. There are a few, but only a few, exceptions. The most significant is Jerry L. Mashaw, Norms, Practices, and the Paradox of Deference: A Preliminary Inquiry into Agency Statutory Interpretation, 57 Admin. L. Rev. 501 (2005) [hereinafter Mashaw, Paradox of Deference]. A more recent contribution is $\mathrm{H}$. Jefferson Powell, The Executive and the Avoidance Canon, 81 Ind. L.J. 1313 (2006) [hereinafter Powell, Executive], a short symposium essay that, like this Article, focuses on executive use of the canon of 
The most familiar methods of statutory interpretation come from the courts. They are the tools of a particular institution (an unelected judiciary), ${ }^{3}$ deployed in a particular context (litigation). To speak of statutory interpretation in the executive branch, in contrast, is to speak of a much more diverse set of institutions (including the White House, cabinet departments, executive agencies, and independent agencies) ${ }^{4}$ and a much

constitutional avoidance, but reaches conclusions quite different from mine. A notable earlier work on executive branch statutory interpretation generally is Peter L. Strauss, When the Judge Is Not the Primary Official with Responsibility to Read: Agency Interpretation and the Problem of Legislative History, 66 Chi.-Kent L. Rev. 321 (1990) [hereinafter Strauss, Agency Interpretation].

It is worth distinguishing here between the very few studies of statutory interpretation in the executive branch and the large and growing literature on constitutional interpretation by executive and other nonjudicial actors. This Article focuses on the former, although the latter comes into play in parts of the discussion. See infra Part III.B. The essential literature on nonjudicial constitutional interpretation, containing a wide variety of viewpoints, is already substantial. See, e.g., Congress and the Constitution (Neal Devins \& Keith E. Whittington eds., 2005); Larry D. Kramer, The People Themselves: Popular Constitutionalism and Judicial Review (2004); H. Jefferson Powell, The Constitution and the Attorneys General (1999); Mark Tushnet, Taking the Constitution Away from the Courts (1999) [hereinafter Tushnet, Taking the Constitution Away]; Larry Alexander \& Lawrence B. Solum, Popular? Constitutionalism?, 118 Harv. L. Rev. 1594 (2005) (reviewing Kramer, supra); Larry Alexander \& Frederick Schauer, On Extrajudicial Constitutional Interpretation, 110 Harv. L. Rev. 1359 (1997); Michael C. Dorf \& Barry Friedman, Shared Constitutional Interpretation, 2000 Sup. Ct. Rev. 61; Louis Fisher, Constitutional 1nterpretation by Members of Congress, 63 N.C. L. Rev. 707 (1985); Walter F. Murphy, Who Shall Interpret? The Quest for the Ultimate Constitutional Interpreter, 48 Rev. Pol. 401 (1986); Michael Stokes Paulsen, The Most Dangerous Branch: Executive Power to Say What the Law Is, 83 Geo. L.J. 217 (1994); Christopher L. Eisgruber, The Most Competent Branches: A Response to Professor Paulsen, 83 Geo. L.J. 347 (1994); Sanford Levinson, Constitutional Protestantism in Theory and Practice: Two Questions for Michael Stokes Paulsen and One for His Critics, 83 Geo. L.J. 373 (1994); Cornelia T.L. Pillard, The Unfulfilled Promise of the Constitution in Executive Hands, 103 Mich. L. Rev. 676 (2005); Robert C. Post \& Reva B. Siegel, Legislative Constitutionalism and Section Five Power: Policentric Interpretation of the Family and Medical Leave Act, 112 Yale L.J. 1943 (2003); Symposium, Executive Branch Interpretation of the Law, 15 Cardozo L. Rev. 21 (1993); David Barron, Constitutionalism in the Shadow of Doctrine: The President's NonEnforcement Power, Law \& Contemp. Probs., Winter/Spring 2000, at 6I; Dawn E. Johnsen, Functional Departmentalism and Nonjudicial Interpretation: Who Determines Constitutional Meaning?, Law \& Contemp. Probs., Summer 2004, at 105.

3. This Article is confined to statutory interpretation by branches of the federal government. I do not address statutory interpretation at the state level, where some judges are democratically elected.

4. By understanding "executive branch" in this broad sense, I follow the dominant trend in contemporary scholarship of placing the administrative state within the executive branch rather than in some fourth, constitutionally unidentified, branch. See Lisa Schultz Bressman, Judicial Review of Agency Inaction: An Arbitrariness Approach, 79 N.Y.U. L. Rev. 1657, 1677 (2004) (noting that "[a]ll or nearly all scholars" endorse view of administrative state that "squares [agency] decisionmaking with the formal structure of our three-branch government by relocating agencies from the headless fourth branch to the executive branch"). I do not, however, mean to endorse any stridently "unitary" conception of the executive branch that treats administrative action as both subject to comprehensive presidential control and directly expressive of presidential will. Locating 
broader array of interpretive contexts (from the formal reasoning of a legal opinion or rule announcement, to the informal interpretations implicit in an agency field manual, to the perhaps entirely unarticulated interpretations that produce executive inaction).$^{5}$ Yet despite these differences, the prevailing assumption appears to be that executive actors can and should employ the judicial canons of statutory interpretation just as readily as any court. ${ }^{6}$ That assumption needs examining. ${ }^{7}$

This Article focuses on the executive use of one prominent rule of statutory interpretation-the canon of constitutional avoidance. Known colloquially as the avoidance canon, it is most commonly described as providing that "where an otherwise acceptable construction of a statute would raise serious constitutional problems, the Court will construe the statute to avoid such problems unless such a construction is plainly contrary to the intent of Congress." ${ }^{8}$ And although it is the target of much academic criticism, ${ }^{9}$ it appears frequently in judicial opinions and has

the administrative state within the executive branch surely posits some nontrivial connection between agencies and the President, but one can accept that connection without subscribing to an aggressive articulation of the unitary executive thesis or otherwise suggesting that the executive branch is an undifferentiated monolith. See Mashaw, Paradox of Deference, supra note 2, at 507 ("One need not believe in some constitutionally problematic version of 'the unitary executive' to believe that political control over administration by elected chief executives is a critical feature of our democratic constitutional order and one that should shape agency approaches to the interpretation of statutes.").

5. See Mashaw, Paradox of Deference, supra note 2, at 525-26 (noting variations in "occasions," "forms," and "processes" of executive branch statutory interpretation).

6. See, e.g., William N. Eskridge, Jr., Philip P. Frickey \& Elizabeth Garrett, Legislation and Statutory Interpretation 323 (2d ed. 2006) (stating that "[i]n construing statutes, agencies consider the same sources private lawyers and public judges do," though also noting that agencies "are .. . better informed about the statutory history and the practicality of competing policies than courts are"); see also sources cited infra notes $125-126,128-130$.

7. Cf. Cass R. Sunstein \& Adrian Vermeule, Interpretation and lnstitutions, $101 \mathrm{Mich}$ L. Rev. 885, 886 (2003) ("The central question is not 'how, in principle, should a text be interpreted?' The question instead is 'how should certain institutions, with their distinctive abilities and limitations, interpret certain texts?' ").

8. Edward J. DeBartolo Corp. v. Fla. Gulf Coast Bldg. \& Constr. Trades Council, 485 U.S. 568,575 (1988). There is some variation in the way the rule is articulated, and 1 discuss that variation below. See infra text accompanying notes 42-48.

9. See infra Part II.B. I discuss in that section the leading scholarly criticisms of the avoidance canon. In addition, however, the last half century has seen considerable academic skepticism about the canons of statutory interpretation more generally. The classic critique is Karl Llewellyn's, in which he contended that for virtually every canon there is a counter canon pointing in the opposite direction, and thus that the canons do not help resolve real cases. See Karl N. Llewellyn, Remarks on the Theory of Appellate Decision and the Rules or Canons About How Statutes Are to Be Construed, 3 Vand. L. Rev. 395, 40I-06 (1950). Over the last two decades, a number of legal process and other scholars have endeavored to rehabilitate the canons' academic standing. In part, this rehabilitation has involved asserting that the canons bave more analytical value than Llewellyn allowed, and showing that most of Llewellyn's opposing pairs are really just general rules set against certain exceptions. See Eskridge et al., supra note 6, at 382; see 
long been embraced by the Supreme Court as a “'cardinal principle' of statutory interpretation." 10

1 focus on the avoidance canon not just because of its status in the courts, but also because of its role in the work of the executive branch. That role has been particularly significant in recent years. Indeed, avoidance has taken center stage in many of the most controversial episodes of executive branch legal interpretation relating to the "war on terror." It appeared prominently, for example, in the leaked (and later withdrawn)

also Antonin Scalia, Common-Law Courts in a Civil-Law System: The Role of the United States Federal Courts in Interpreting the Constitution and Laws, in A Matter of Interpretation 3, 26-27 (Amy Gutmann ed., 1997). Others have noted that although the canons may not dictate particular results in every case, they do help structure controversies about statutory meaning by identifying a relevant set of "background principles," Cass $\mathbf{R}$. Sunstein, Interpreting Statutes in the Regulatory State, 103 Harv. L. Rev. 405, 451 (1989), and that this is especially true for "substantive" canons (like avoidance), which Llewellyn's critique did not address. See William N. Eskridge, Jr. \& Philip P. Frickey, QuasiConstitutional Law: Clear Statement Rules as Constitutional Lawmaking, 45 Vand. L. Rev. 593, 595 (1992) [hereinafter Eskridge \& Frickey, Quasi-Constitutional Law]. The defenders also acknowledge, however, tbat the canons" "rule-like façade . . . tends to conceal the value choices that underlie them and encourages judges and advocates to attempt to formulate their debatable propositions in canonical form to shield themselves from critical analysis." Eskridge et al., supra note 6, at 383. But the problem there is not with the canons themselves; it is with their uncritical, mechanical application. To remedy that problem, the deployment of any particular canon should come only after careful consideration of the values it is meant to serve, as well as the fit between those values and the context of the interpretation. As I discuss further in the text, the aim of this Article is to provide the analytical tools for considering those very matters with respect to the executive use of the avoidance canon.

10. Zadvydas v. Davis, 533 U.S. 678, 689 (2001) (quoting Crowell v. Benson, 285 U.S. $22,62(1932))$. In the last two decades alone, the Court has invoked the avoidance canon on numerous occasions and in a range of contexts. See, e.g., id. at 699 (construing provision of Immigration and Nationality Act to impose certain time limits on detention of certain removable aliens, in order to avoid "serious constitutional threat" posed by indefinite detention); 1NS v. St. Cyr, 533 U.S. 289, 299-300 (2001) (concluding Congress had not stripped courts of jurisdiction to entertain habeas corpus petitions contesting removal orders on grounds of legal error, in part because doing so would raise "substantial constitutional questions" under Suspension Clause); Solid Waste Agency v. U.S. Army Corps of Eng'rs, 531 U.S. 159, 172-74 (2001) (concluding provisions in Clean Water Act regarding "navigable waters" do not include purely intrastate waters used as habitat for migratory birds, in part because doing so would raise significant questions about Congress's authority under Commerce Clause to reach such areas); Vt. Agency of Natural Res. v. United States ex rel. Stevens, 529 U.S. 765, 787 (2000) (construing federal qui tam statute not to apply to actions against states, in part because of "serious doubt" whether sucb application would violate Eleventh Amendment); United States v. X-Citement Video, 1nc., 513 U.S. 64, 69 (1994) (construing Protection of Children Against Sexual Exploitation Act to include certain scienter requirements, in part to "avoid substantial constitutional questions"); Pub. Citizen v. U.S. Dep't of Justice, 491 U.S. 440, 467 (1989) (adopting narrow construction of Federal Advisory Committee Act in part out of "unwillingness to resolve important constitutional questions unnecessarily"); Edward J. DeBartolo Corp., 485 U.S. at 575 (construing unfair labor practices provisions of National Labor Relations Act not to cover handbill distribution, so as to avoid "serious constitutional problems" under First Amendment). 
"torture memorandum" issued by the Justice Department's Office of Legal Counsel, " in the Justice Department's defense of the National Security Agency's warrantless wiretapping program, ${ }^{12}$ and in President George W. Bush's narrow construction of a statute banning the cruel, inhuman, or degrading treatment of detainees. ${ }^{13}$ I discuss each of those examples in this Article, and in that respect the Article is partially about the executive's legal arguments in the war on terror. But the executive's use of avoidance is hardly confined to that context. Invocations of avoidance may also be found in a range of matters not reaching the front pages of the newspaper, including the more routine interpretive activities of various administrative agencies. ${ }^{14}$ I address examples of that sort as well.

Uniting virtually all executive uses of the avoidance canon, infamous or obscure, is a failure to examine whether it should apply at all in the executive branch. Instead, the interpreter typically asserts that since the courts employ avoidance, " $[\mathrm{t}]$ he practice of the executive branch is and should be the same." 15 Totally lacking in such statements is any consideration of whether the reasons supporting the judicial use of avoidance are relevant in the executive branch. Those reasons need examining. Are they specific to the federal judiciary-for example, do they seek to facilitate judicial deference to legislative majorities, to minimize countermajoritarianism, or to respect the "case or controversy" limitations of Article III-or do they seek to serve other substantive norms not confined to the courts? Also lacking is any sustained examination of interpretive context. As described by the courts, the avoidance canon applies only in circumstances of statutory ambiguity. ${ }^{16}$ Can executive branch actors ever overcome ambiguity by calling upon sources of statutory meaning not available to courts, thus rendering the avoidance canon unnecessary? 1n short, determining the propriety of constitutional avoidance in the executive branch should entail considering both the theory underlying the canon and the particular context in which it will be deployed.

These considerations are particularly important in view of the fact that politics has an entirely appropriate role in the executive branch. By politics, I mean discretionary considerations of policy and even ideology, as opposed to the mandatory (though often malleable) constraints of le-

11. See infra text accompanying notes 179-186.

12. See infra Part IV.B.3.

13. See infra Part IV.B.2.

14. See infra Part 1II.A.

15. Presidential Certification Regarding the Provision of Documents to the House of Representatives Under the Mexican Debt Disclosure Act of 1995, 20 Op. Off. Legal Counsel 253, 265 (1996).

16. The circumstances in which ambiguity will be deemed to have given way to clarity, including the question whether an express statement is required to force adoption of the doubts-raising construction, is a matter of some disagreement. See infra text accompanying notes $113-118$. 
gal rules. ${ }^{17}$ In a way less true of the courts, both of these elements may be legitimately present in the actions of the executive branch. Yet we cannot intelligently appraise any of those actions without identifying the relative contributions of each element. As Peter Strauss has observed, "Because part of what distinguishes agencies from courts in . . . statute-reading is that we accept a legitimate role for current politics in the work of agencies, the question then becomes, in important respects, titrating just how much politics and just how much law there is in the mixture." 18

With that in mind, I aim in this Article to provide the analytical tools for evaluating executive uses of the avoidance canon. ${ }^{19}$ By considering both the underlying values ostensibly served by the canon and the precise institutional posture of the interpretation in question, we can determine whether any particular executive use of the canon is justified on its own terms. That, in turn, will enable us to "titrat[e]" the relative mix of law and politics in the executive's actions. ${ }^{20}$ If the executive's use of avoidance in a particular case does not accord with the canon's own terms, then it may be appropriate to view the government's actions as driven more by politics than by law. Indeed, in such circumstances we may fairly suspect that the government has invoked avoidance in an effort to cover a fundamentally political decision with the veneer of legal obligation.

Part I of the Article begins by identifying some basic issues framing the inquiry. In particular, I note the distinction between executive interpretations that yield justiciable controversies and those where the courts are unlikely ever to become involved. I then explain why it makes sense, for purposes of the present inquiry, to set aside the prospect of judicial review when considering even those interpretations likely to face that review.

Part II moves to the avoidance canon. 1 discuss two different theoretical accounts of the canon: the conventional account, which I call the judicial restraint theory and which sees the canon as serving considerations specific to the judiciary; and an alternative account, which I call the

17. Of course, law and politics are not mutually exclusive, and an executive official's views on each may derive from a common set of ideological or other commitments. But as Chief Justice Marshall recognized in Marbury $v$. Madison, some distinction can be drawn between areas where the law imposes specific duties or obligations on the government, and those where the government enjoys greater discretion and is "only politically examinable" for its actions. 5 U.S. (1 Cranch) 137, 166 (1803); see also id. at 165-73 (elaborating on distinction in course of describing circumstances in which writ of mandamus might appropriately be directed against executive officer).

18. Strauss, Agency Interpretation, supra note 2, at 335; see also id. at 322 ("Politics has an open and conceded role in administrative government, as it does not for courts; and yet we also expect an agency to act according to law."). Although Professor Strauss here refers just to administrative agencies, the point holds for the entire executive branch.

19. Although my focus in this Article is on the avoidance canon, I hope the approach I employ here-considering both the theoretical justification for the canon and the specific context in which it is employed-might prove useful when addressing other questions of executive branch statutory interpretation as well.

20. Strauss, Agency Interpretation, supra note 2, at 335 . 
constitutional enforcement theory and which sees the canon as providing a means of enforcing the underlying constitutional provision in a way that is not necessarily specific to the judiciary. My main purpose is not to reach a definitive conclusion about which account is best, but simply to emphasize that the avoidance canon, like any interpretive rule, may be justified on different grounds.

Part 1II considers the avoidance canon in the executive branch. I survey circumstances in which various executive branch actors have invoked the avoidance canon, and I contend that whether any of those invocations is justifiable depends, in part, on whether one adopts the judicial restraint or constitutional enforcement theory of avoidance. On the former theory, avoidance would appear to have no place in the executive branch. On the Iatter, it may well be appropriate for executive actors to employ avoidance as part of the President's independent duty to abide by and protect the Constitution.

Part IV discusses the other governing consideration-interpretive context. I argue that because the avoidance canon is only triggered in situations of statutory ambiguity, it should be inapplicable in cases where the executive interpreter's knowledge of congressional intent and statutory purpose removes the statute's ambiguity. The "information richness" of at least some instances of executive statutory interpretation suggests that, even though a court might employ avoidance in a particular situation, it could be unnecessary and even inappropriate for the executive branch to do so. Indeed, in circumstances where the relevant executive actor has enough extratextual information about statutory meaning to resolve any statutory ambiguity without recourse to avoidance, it is fair to suspect that the deployment of avoidance may be in the service of politics, not law.

\section{Framing the Issue: Statutory Interpretation Outside The Courts}

To examine the avoidance canon in executive branch statutory interpretation is, obviously, to examine one facet of statutory interpretation outside the courts. That enterprise raises an important threshold question: When thinking about executive branch statutory interpretation, how, if at all, should we account for the prospect of judicial review? In this Article, I propose to consider executive use of the avoidance canon without regard to judicial review. I explain why in this opening section.

It is first worth observing that in a great many instances of executive branch statutory interpretation, the question of judicial review does not arise. 1 refer here to cases where the executive's interpretation is not subject to judicial review either because it does not affect any particular individual, because those affected have no cause of action or lack stand- 
ing to sue, or because the case is otherwise nonjusticiable. ${ }^{21}$ In matters implicating foreign affairs and national security, for example, judicial review of executive branch statutory interpretation is extremely infrequent. ${ }^{22}$ In areas like these, to think about executive branch statutory interpretation is necessarily to think about that process without regard to the prospect of judicial review.

There are, of course, numerous other circumstances in which the executive's interpretation is subject to later review by the courts. That review is structured by a number of administrative law and other doctrines, most notably the familiar Chevron framework. ${ }^{23}$ In these cases, as a practical matter, the executive branch ignores the prospect of judicial review at its peril. If an agency knows that its construction of a statute will likely face judicial review, and if the reviewing court would predictably use a particular canon when construing the statute, then the agency has a tactical incentive to apply the canon even if the values supporting it apply only to the judiciary. Indeed, if the canon is likely to be outcome determinative, the agency's failure to apply it would invite reversal. ${ }^{24}$

Although I acknowledge the practical force of the incentives just described, for present purposes I want to examine executive branch statutory interpretation independent of the prospect of judicial review. In doing so, I operate from the premise that cases in which the executive

21. See Randolph D. Moss, Executive Branch Legal Interpretation: A Perspective from the Office of Legal Counsel, 52 Admin. L. Rev. 1303, 1304 (2000) ("In the vast majority of cases ... executive branch interpretation is not subjected to judicial review."). Henry Monaghan has made a similar point regarding constitutional interpretation. See Henry P. Monaghan, Marbury and the Administrative State, 83 Colum. L. Rev. 1, 6 n.33 (1983) (" $[\mathrm{C}]$ onstitutional questions may arise outside the adjudicatory context-for example, where no plaintiff has standing." (citation omitted)).

22. Cf. Dames \& Moore v. Regan, 453 U.S. 654, 660-61 (1981) (noting, in case challenging executive agreement arising out of lran hostage crisis, that there is "broad range of vitally important day-to-day questions regularly decided by Congress or the Executive, without either challenge or interference by the Judiciary, [and] that the decisions of the Court in this area have been rare, episodic, and afford little precedential value for subsequent cases").

23. See Chevron U.S.A. Inc. v. Natural Res. Def. Council, Inc., 467 U.S. $837,842-43$ (1984) (holding that courts must defer to agency's construction of ambiguity or gap in statute agency administers, provided construction is reasonable).

24. In the case of the avoidance canon, this is true even in circumstances where the agency's interpretation might otherwise he entitled to judicial deference under Cheoron. As the Supreme Court has made clear, the avoidance canon is one of the ordinary tools of statutory interpretation that reviewing courts must employ at the first step of Chevron's twostep inquiry. See Solid Waste Agency v. U.S. Army Corps of Eng'rs, 531 U.S. 159, 172-74 (2001); Edward J. DeBartolo Corp. v. Fla. Gulf Coast Bldg. \& Constr. Trades Council, 485 U.S. 568, 574-75 (1988). Because (as discussed later in the text) the avoidance canon only applies in circumstances of statutory ambiguity, and because its application effectively removes that ambiguity from the statute, applying the avoidance canon at the first step of the Chevron inquiry removes the statutory ambiguity that would otherwise have compelled judicial deference to reasonable executive interpretations at the second step of the inquiry. For a critique of this approach, see Thomas W. Merrill \& Kristin E. Hickman, Cheuron's Domain, 89 Geo. L.J. 833, 914-15 (2001). 
uses a particular canon only because a reviewing court will later use that canon stand on a different normative footing than cases in which there is an institutionally relevant justification for the canon. Suppose, for example, that we were to conclude that the avoidance canon serves values peculiar to the federal courts and thus that it has no direct relevance to the executive branch. In that circumstance, if the executive's interpretation of a statute is subject to judicial review and if the courts will employ avoidance when they construe the statute, then the executive risks reversal unless it interprets the statute with the aid of an institutionally inappropriate interpretive device. The tactical incentives created by the prospect of judicial review thus produce a kind of methodological imperialism, where the executive's independent power and duty to "take Care that the Laws [are] faithfully executed" 25 is cabined by the need to interpret the laws according to the judiciary's methods, lest its interpretation be rejected. ${ }^{26}$ If, on the other hand, the avoidance canon serves values relevant to the executive as well as the judicial branch, then the executive's use of the canon is justifiable on the canon's own terms. In that circumstance, judicial reversal of the executive's interpretation merely corrects an error in the executive's application of a rule it is justifiably expected to follow. ${ }^{27}$ It does not require the executive branch to adopt an interpretive rule that makes no sense within that branch. Accordingly, we cannot adequately assess any executive use of the avoidance canon without knowing why it happens, and we cannot make that determination without setting judicial review aside and thinking about the canon's relevance to the executive branch on its own terms.

There are at least two potential objections to the approach I have just proposed. First, one might raise a rule-of-law objection. That is, one might contend that by asking whether the avoidance canon is relevant to the executive branch on its own terms, I am allowing that the executive and judicial branches might read the same statutes differently, according

25. U.S. Const. art. II, § 3 .

26. William Kelley criticizes the judicial use of avoidance on this very ground, reflecting an assumption that avoidance is not appropriate in the executive branch on its own terms. See William K. Kelley, Avoiding Constitutional Questions as a Three-Branch Problem, 86 Cornell L. Rev. 831, 834 (2001). I discuss Professor Kelley's argument in greater detail in Part II.B, infra.

27. For an argument that judicial review of agency statutory interpretation should include examination of both the substance and the methods of the interpretation, see Bernard W. Bell, Using Statutory Interpretation to Improve the Legislative Process: Can It Be Done in the Post-Cheuron Era?, 13 J.L. \& Pol. 105 (1997). Professor Bell focuses on "the effect that methodology used to interpret statutes can have on the legislative process," notes that such effects can be caused by both judicial and agency choice of methodology, and argues that "in ceding to agencies the power to decide issues of interpretive methodology, the courts bave unwisely deprived themselves of the ability to control the effects that such methodology can have on the legislative process." Id. at 106 . To the extent we properly expect both courts and agencies to respect the process values identified by Professor Bell, his proposal for judicial review of agency interpretive methodology is comparable to the less intrusive of the two scenarios I have identified in the text. 
to different rules. And that, one might argue, could raise serious rule-oflaw concerns. ${ }^{28}$ To be sure, there is considerable appeal in the idea that the meaning of a statute should not vary with the institution interpreting it. If a court's application of a certain interpretive rule would be outcome determinative, one might be concerned that the executive's failure to employ that rule would "create an anomalous situation where the accepted rules of agency conduct would conflict with the rules available to parties in court." 29 The operative legal standard would thus depend at least in part on whether the affected party can "purchase" a different legal rule by pursuing its case into the courts. ${ }^{30}$ To minimize such inconsistencies, one might argue that the executive and judicial branches should employ a common set of interpretive rules.

It is beyond the scope of this Article to reach any definitive conclusion about whether the rule of law demands that all arms of government always use the same methods when interpreting the same statutes. I concede, however, that a divergence in the respective interpretive methodologies of the judicial and executive branches could lead to undesirable inconsistencies in the law. Surely, we should try to minimize those inconsistencies to the extent it can be done without intolerably sacrificing other important values. But that does not mean we should impose all judicially developed tools of statutory construction on the executive branch without any thought to their fit. We still need to know whether any particular judicially developed rule applies of its own force in the executive branch. If it does, then the risk of interpretive divergence does not materialize. If it does not, then deciding whether the executive

28. I refer here to the foundational-indeed, Aristotelian-principle that like cases should be decided alike, which might be understood to demand interinstitutional consistency. See John E. Coons, Consistency, 75 Cal. L. Rev. 59, 59 (1987) ("Like cases should be treated alike: This formula of Aristotle is widely accepted as a core element of egalitarian moral and social philosophy." (footnote omitted)); Richard J. Pierce, Jr., Political Control Versus Impermissible Bias in Agency Decisionmaking: Lessons from Cheuron and Mistretta, 57 U. Chi. L. Rev. 48I, 507 (I990) ("[Clonsistency in adjudication is a due process value: we want our legal system to produce like results in like cases.").

29. Matthew Diller \& Nancy Morawetz, Intracircuit Nonacquiescence and the Breakdown of the Rule of Law: A Response to Estreicher and Revesz, 99 Yale L.J. 801, 823 (1990). Diller and Morawetz made this point not with respect to the applicability of the avoidance canon in the executive branch, but in the somewhat analogous context of debates about "administrative agency nonacquiescence." Id. at 801 . The term refers to an agency's refusal to apply the law of the federal court of appeals with jurisdiction to review its actions. Id. Although uniformly condemned by the courts, the practice was robustly defended by Samuel Estreicher and Richard Revesz. See Samuel Estreicher \& Richard L. Revesz, Nonacquiescence by Federal Administrative Agencies, 98 Yale L.J. 679 (1989). Diller and Morawetz disagreed with that defense and argued, among other things, that agency nonacquiescence produces unfairness by creating a system where the applicable legal rule depends on whether the parties can afford to sue in court. See Diller \& Morawetz, supra, at 829. For the rejoinder of Professors Estreicher and Revesz, see Samuel Estreicher \& Richard L. Revesz, The Uneasy Case Against Intracircuit Nonacquiescence: A Reply, 99 Yale L.J. 831 (1990).

30. Diller \& Morawetz, supra note 29 , at 829. 
branch should adopt the rule would entail weighing the consistency and rule-of-law benefits of doing so against the costs, noted above, ${ }^{31}$ of imposing an institutionally inappropriate interpretive device upon the executive branch.

Interpretive consistency, moreover, is achievable in different ways. To the extent the costs associated with imposing institutionally inappropriate methods on the executive branch seem intolerable, consistency could be achieved by requiring the courts to employ only those methods that are appropriate in both the judicial and executive branches. That is, if executive use of the avoidance canon cannot be justified on its own terms, we might decide both that the executive branch should not have to employ avoidance and that the courts should not use it when reviewing executive actions. But we cannot know whether even to consider this course without first determining whether, on its own terms, the avoidance canon is appropriate in executive branch interpretation.

This leads to a second potential objection-that ignoring the prospect of judicial review constitutes an attack on the ultimate authority of the courts to "say what the law is." 32 That attack is furthered, one might think, by my suggestion that judicial review of executive interpretations should perhaps use only those tools that are appropriate within the executive branch.

This objection overestimates my proposal. To be sure, it would be possible to use an examination of executive branch statutory interpretation as a vehicle for challenging the interpretive supremacy of the courts. But it is not necessary to do so, nor is it my aim. The literature on nonjudicial constitutional interpretation provides an instructive analogy. ${ }^{33} \mathrm{Al}-$ though some contributions to that literature mount frontal attacks on judicial supremacy in constitutional interpretation, ${ }^{34}$ others do not. lnstead, they highlight the role of nonjudicial actors in constitutional interpretation while still acknowledging the ultimate authority of the courts. ${ }^{35}$ Commentators taking this approach treat constitutional interpretation as "a collaborative enterprise in which each branch should recognize its own limitations and the relative strengths and functions of the other coordinate branches," ${ }^{6}$ but they accept that the Supreme Court retains the final say in resolving the constitutional disputes that come before it. Thus, for example, some commentators argue that the "rational basis" test, while an appropriate restraint on most judicial review of state action

31. See supra text accompanying notes $25-26$.

32. Marbury v. Madison, 5 U.S. (1 Cranch) 137, 177 (1803).

33. Some of that literature is cited in note 2, supra.

34. See, e.g., Tushnet, Taking the Constitution Away, supra note 2; Paulsen, supra note 2 .

35. See, e.g., Dorf \& Friedman, supra note 2, at 62, 63 n.10 (treating constitutional interpretation as a "shared institutional process" while distinguishing their argument from work that "sweeps too far in denying the Court's supremacy with regard to constitutional interpretation").

36. Johnsen, supra note 2, at 109. 
under the Due Process and Equal Protection Clauses of the Fourteenth Amendment, need not confine Congress's power to pass legislation enforcing that Amendment. ${ }^{37}$ As Robert Post and Reva Siegel put it, "Because the considerations of 'judicial restraint' that shape and guide rational basis review are specifically designed to prevent courts from intruding on legislative discretion, they ought not to prevent Congress from applying the prohibition against invidious discrimination in a procedurally different and more comprehensive way than a court." 38 Nothing in this argument undermines the authority or finality of judicial review in constitutional cases. Instead, the point is simply that, in light of the different institutional characteristics of each branch of government, courts should sometimes grant one or the other coordinate branches leeway to implement the Constitution according to rules that differ from the ones that courts themselves would apply. ${ }^{39}$

My approach to executive branch statutory interpretation is similar. That is, by focusing on the arguments for and against constitutional avoidance in the executive branch without regard to the prospect of judicial review, I am not denying the ultimate authority of the courts to resolve disputes over statutory meaning. But accepting judicial supremacy in such matters does not tell us how to evaluate an executive actor's decision to use the avoidance canon in a particular case. To do that, we need to think about the justifications for the canon and their relevance to the executive branch. Moreover, by suggesting that if avoidance is ill suited to the executive branch then perhaps the courts should forgo it when reviewing executive interpretations, 1 am not proposing that the judiciary

37. See, e.g., Robert C. Post \& Reva B. Siegel, Equal Protection by Law: Federal Antidiscrimination Legislation After Morrison and Kimel, 110 Yale L.J. 441, 462-67 (2000) [hereinafter Post \& Siegel, Equal Protection]; Lawrence Gene Sager, Fair Measure: The Legal Status of Underenforced Constitutional Norms, 91 Harv. L. Rev. 1212, 1228-42 (1978).

38. Post \& Siegel, Equal Protection, supra note 37, at 467; see also Michael W. McConnell, lnstitutions and Interpretation: A Critique of City of Boerne v. Flores, 111 Harv. L. Rev. 153, 189 (1997) ("The difference between congressional and judicial enforcement of the Fourteenth Amendment is that Congress is not limited by the institutional concerns associated with judicial restraint."). So far, this argument has received only four votes at the Supreme Court. See Bd. of Trs. v. Garrett, 531 U.S. 356, 383 (2001) (Breyer, J., dissenting, joined by Stevens, Souter \& Ginsburg, JJ.) (" $[\mathrm{N}]$ either the 'burden of proof' that favors States nor any other rule of restraint applicable to judges applies to Congress when it exercises its $\$ 5$ power."); id. at 384-85 (contending that "[t]here is simply no reason to require Congress, seeking to determine facts relevant to the exercise of its $\S 5$ authority, to adopt rules or presumptions that reflect a court's institutional limitations," and asserting that "[ $\mathrm{t}$ ]o apply a rule designed to restrict courts as if it restricted Congress' legislative power is to stand the underlying principle-a principle of judicial restraint-on its head").

39. See, e.g., Richard H. Fallon, Jr., Implementing the Constitution 72 (2001) ("This interpretive conception would not threaten the Court's position as ultimate constitutional decision maker. . . . In cases of reasonable disagreement, however, Congress's power to 'enforce' the Constitution would encompass a power to interpret and implement the Constitution through appropriate legislation."). 
cede its interpretive supremacy to the executive branch. Rather, 1 am suggesting that courts should perhaps be more sensitive to interinstitutional considerations when choosing their interpretive tools.

$$
* * *
$$

My aim in this section has been to explain why a full assessment of constitutional avoidance in the executive branch requires setting aside the prospect of judicial review. The next section lays the groundwork for that assessment.

\section{The Avoidance Canon in the Courts}

To assess whether the avoidance canon should apply in the executive branch, we need to know more about how the courts have developed and justified it. On any account, avoidance is a "substantive" canon. ${ }^{40}$ It operates in the service of underlying substantive-especially constitutionalvalues. ${ }^{41}$ The aim of this section is to identify those values. To that end, I summarize the emergence of the avoidance canon in judicial opinions, describe the conventional theory of the rule and the leading objections to it, and then identify an alternative theory. My principal aim here is not to argue the relative merits of the two theories of avoidance, but to describe them and to identify the constitutional values they purport to advance.

\section{A. The Conventional Theory of Modern Avoidance: Judicial Restraint}

In this subsection, I trace the evolution of the avoidance canon and the emergence of the most common theoretical account of the rule. I begin by noting that although we speak colloquially of a single avoidance canon, two related but distinct rules travel under the avoidance banner. The first, which Adrian Vermeule calls "classical avoidance," ${ }^{42}$ provides that "as between two possible interpretations of a statute, by one of wbich it would be unconstitutional and by the other valid, [a court's] plain duty is to adopt that which will save the Act."43 The second, which Professor Vermeule calls "modern avoidance," 44 is the one most frequently invoked

40. See William N. Eskridge, Jr., Dynamic Statutory Interpretation 276 (1994) [hereinafter Eskridge, Dynamic Statutory Interpretation] (identifying three categories of interpretive canons: "precepts of grammar, syntax, and logical inference (the textual canons); rules of deference to the interpretations others have placed on the statutory language (the extrinsic source canons); and policy rules and presumptions (the substantive canons) $"$ ). The textual, extrinsic source, and substantive canons are discussed at length in Eskridge et al., supra note 6, at 257-387.

41. See Eskridge et al., supra note 6, at 342 (describing substantive canons generally); id. at 360-67 (describing avoidance as substantive canon).

42. See Adrian Vermeule, Saving Constructions, 85 Geo. L.J. 1945, 1949 (1997).

43. Blodgett v. Holden, 275 U.S. 142, 148 (1927) (Holmes, J., concurring in the judgment of an equally divided court).

44. See Vermeule, supra note 42, at 1949. Professor Vermeule's terminology has been adopted by others writing in this area. See Kelley, supra note 26, at 840; Ernest A. Young, 
by the courts today and is the one with which this Article is principally concerned. There is some variation in how it is described, but the standard articulation is the one quoted in the Introduction: "[W] here an otherwise acceptable construction of a statute would raise serious constitutional problems, the Court will construe the statute to avoid such problems unless such construction is plainly contrary to the intent of Congress." 45

The critical difference between classical and modern avoidance, of course, is in the level of constitutional concern needed to trigger the rule. Under classical avoidance, the court must "reach the issue whether the doubtful version of the statute is constitutional [and conclude that it is not] before adopting the construction that saves the statute from constitutional invalidity." 46 Under modern avoidance, in contrast, the court must merely conclude that "an otherwise acceptable construction of a statute wouId raise serious constitutional problems." 47 In short, modern avoidance departs from classical avoidance by allowing serious but potentially unavailing constitutional objections to dictate statutory meaning. ${ }^{48}$

How did we get from classical to modern avoidance? As the labels suggest, the classical version has a longer history than the modern. ${ }^{49}$ From the beginning, classical avoidance has been justified on two related grounds. The first is the presumption that members of Congress, as part of a coordinate branch of government, have kept their oaths to uphold

Constitutional Avoidance, Resistance Norms, and the Preservation of Judicial Review, 78 Tex. L. Rev. 1549, 1575-76 (2000). 1 will use it as well.

45. Edward J. DeBartolo Corp. v. Fla. Gulf Coast Bldg. \& Constr. Trades Council, 485 U.S. 568,575 (1988).

46. Clark v. Martinez, 543 U.S. 371, 395 (2005) (Thomas, J., dissenting). In that respect, "[c]lassical avoidance does not avoid, but in fact decides, a constitutional question." Vermeule, supra note 42, at 1959.

47. Edward J. DeBartolo Corp., 485 U.S. at 575.

48. See John Copeland Nagle, Delaware $\mathcal{F}^{\circ}$ Hudson Revisited, 72 Notre Dame L. Rev. $1495,1496-97$ (1997) ("The most noticeable difference between the two rules is that [classical avoidance] requires a court to decide the constitutional question while [modern avoidance] allows a court to avoid any such decision."); Vermeule, supra note 42, at 1949 ("The basic difference between classical and modern avoidance is that the former requires the court to determine that one plausible interpretation of the statute would be unconstitutional, while the latter requires only a determination that one plausible reading might be unconstitutional.").

49. Classical avoidance can be traced at least to Murray v. The Schooner Charming Betsy, 6 U.S. (2 Cranch) 64 (1804). See Edward J. Debartolo Corp., 485 U.S. at 575 (noting these origins). In The Charming Betsy, Chief Justice Marshall observed that "an act of Congress ought never to be construed to violate the law of nations if any other possible construction remains." 6 U.S. (2 Cranch) at 118. Although the law of nations is not the Constitution, the principle that statutes ought to be construed to avoid conflict with fundamental law is essentially the same. See Kelley, supra note 26, at 837-38 (discussing The Charming Betsy as origin of avoidance canon). Professor Vermeule suggests that classical avoidance's origins may be even earlier. See Vermeule, supra note 42, at 1948 n.13 (citing Mossman v. Higginson, 4 U.S. (4 Dall.) 12 (1800)). Justice Thomas appears to agree. See Clark, 543 U.S. at 395 n.2 (Thomas, J., dissenting) (citing both Mossman, 4 U.S. (4 Dall.) 12 and Vermeule, supra note 42 ). 
the Constitution. As Thomas Cooley explained, "the court must construe the statute in accordance with the legislative intent; since it is always to be presumed the legislature designed the statute to take effect, and not to be a nullity." 50 Second, classical avoidance minimizes the instances of judicial review in which an unelected court invalidates the work product of the democratically accountable branches. ${ }^{51}$ As William Kelley has explained, "courts and commentators have worried for generations about judicial review precisely because legislative supremacy is a fundamental premise of democratic self-government." ${ }^{52}$ Classical avoidance speaks to that worry by directing judges to avoid holding statutes unconstitutional. In that way, it "confines the judiciary to its proper role in construing statutes." 53

The Supreme Court's move from classical to modern avoidance is generally traced to United States ex rel. Attorney General v. Delaware $\mathcal{E} \mathcal{H} H u d-$ son $\mathrm{Co}^{54}$ In that case, the Court suggested that when a court engages in classical avoidance, it provides what amounts to an advisory opinion on a

50. Thomas M. Cooley, A Treatise on the Constitutional Limitations Which Rest upon the Legislative Power of the States of the American Union 376 (8th ed. 1927); see also Nagle, supra note 48, at 1508 (stating that classical avoidance "depends upon the presumption that the legislature has not actually violated the Constitution-that the members of the legislature heed their oath to uphold the Constitution, and that a coordinate branch of the government takes the Constitution seriously").

51. See Rust v. Sullivan, 500 U.S. 173, 190-91 (1991) (describing classical avoidance as "based at least in part on the fact that a decision to declare an Act of Congress unconstitutional is the gravest and most delicate duty that this Court is called on to perform'" (quoting Blodgett v. Holden, 275 U.S. 142, 148 (1927) (Holmes, J., concurring in the judgment of an equally divided court))).

52. Kelley, supra note 26 , at 844 .

53. NLRB v. Catholic Bishop, 440 U.S. 490, 511 (1979) (Brennan, J., dissenting).

54. 213 U.S. 366 (1909); see Nagle, supra note 48, at 1496 (criticizing modern avoidance and identifying Delaware $\mathcal{E}$ Hudson as "[t]he true culprit" responsible for its rise).

Not everyone agrees that classical avoidance predates modern avoidance, or even that those terms accurately describe the two versions of the canon. William Eskridge, for example, reads Chief Justice Marshall's opinion for the Court in Ex parte Bollman, 8 U.S. (4 Cranch) 75 (1807), issued a century before Delaware $\mathcal{E}$ Hudson, as applying something akin to what Professor Vermeule has termed modern avoidance. See William N. Eskridge, Jr., All About Words: Early Understandings of the "Judicial Power" in Statutory Interpretation, 1776-1806, 101 Colum. L. Rev. 990, 1079-80 (2001) [hereinafter Eskridge, All About Words] (discussing Marshall's statement that "the sound construction'" of section 14 of Judiciary Act of 1789 " 'which the court thinks it safer to adopt,' was the one consistent with a central goal of the Constitution-to assure 'that the privilege of the writ of habeas corpus should not be suspended, unless when, in cases of rebellion or invasion, the public safety might require it'" (quoting Bollman, 8 U.S. (4 Cranch) at 95)). Although Bollman did not involve the formal application of modern avoidance as the Court later articulated it, I agree that the basic structure of the reasoning is similar. As far as I am aware, however, Bollman did not spawn a general practice of construing statutes to avoid constitutional doubts. Rather, it appears that the genealogy of the avoidance canon as currently practiced, including the point at which the Court self-consciously transitioned from avoiding actual unconstitutionality to avoiding constitutional doubts, traces to Delaware E Hudson. 
constitutional issue. ${ }^{55}$ Consider: A court is faced with a statute that could be read to mean either $\mathrm{X}$ or $\mathrm{Y}$. Although both readings are plausible, conventional tools of statutory interpretation (other than avoidance) suggest that $X$ is the best reading. But $X$ also raises serious constitutional concerns. The court proceeds to examine those constitutional concerns and concludes that $\mathrm{X}$ is indeed unconstitutional. At that point, classical avoidance directs the court to read the statute to mean $Y$ instead, thus arguably transforming its pronouncement of X's unconstitutionality into an advisory opinion. ${ }^{56}$ The Delaware $\mathcal{E}$ Hudson Court responded to this problem by inaugurating modern avoidance:

[U]nless this rule be considered as meaning that our duty is to first decide that a statute is unconstitutional and then proceed to hold that such ruling was unnecessary because the statute is susceptible of a meaning, which causes it not to be repugnant to the Constitution, the rule plainly must mean that where a statute is susceptible of two constructions, by one of which grave and doubtful constitutional questions arise and by the other of which such questions are avoided, our duty is to adopt the latter. ${ }^{57}$

It does not matter for present purposes whether the Delaware $\mathcal{E}$ Hudson Court was technically correct in its identification of an advisory problem. (I think it was not, at least by modern standards. ${ }^{58}$ ) Instead, the point here is a historical one-that the Court expanded its avoidance

55. See 213 U.S. at 408.

56. See Kelley, supra note 26 , at 840 (observing that classical avoidance "placed the Court in the apparent position of rendering advisory opinions on constitutional questions"); Nagle, supra note 48, at 1518 (noting that classical avoidance "smacks of an advisory opinion by answering a constitutional question only so that the constitutional holding can be avoided").

57. 213 U.S. at 408 .

58. The modern Supreme Court's cases on qualified immunity make this clear. The doctrine of qualified immunity generally shields government officials from civil damages liability "insofar as their conduct does not violate clearly established statutory or constitutional rights of which a reasonable person would have known." Harlow v. Fitzgerald, 457 U.S. 800,818 (1982). As the Court has explained, the analysis involves two questions: (1) Does the complaint allege a violation of the plaintiff's statutory or constitutional rights?; and (2) were those rights clearly established at the time of the defendant's actions? See, e.g., County of Sacramento v. Lewis, 523 U.S. 833, 841 n.5 (1998) (identifying the two questions). In the Delaware $\mathcal{F}^{\circ}$ Hudson Court's view of unnecessary constitutional rulings, it would be inappropriate for a court first to find that the complaint alleges a constitutional violation but then to grant the defendant immunity on the ground that the right was not clearly established. Yet that is precisely what the Court has instructed:

A court required to rule upon the qualified immunity issue must consider . . this threshold question: Taken in the light most favorable to the party asserting the injury, do the facts alleged show the officer's conduct violated a constitutional right? This must be the initial inquiry. In the course of determining whether a constitutional right was violated on the premises alleged, a court might find it necessary to set forth principles which will become the basis for a holding that a right is clearly established. . . The law might be deprived of this explanation were 
doctrine because it perceived an advisory opinion problem with classical avoidance.

In the years that followed, the Court built on Delaware $\mathcal{F}^{2}$ Hudson by stressing that respect for the proper roles of the legislature and the judiciary requires minimizing the occasions on which the courts will even examine the constitutionality of federal legislation, let alone strike it down. ${ }^{59}$ As Justice Brandeis put it in his classic concurrence in Ashwander v. Tennessee Valley Authority:

The Court has frequently called attention to the "great gravity and delicacy" of its function in passing upon the validity of an act of Congress; and has restricted exercise of this function by rigid insistence that the jurisdiction of federal courts is limited to actual cases and controversies; and that they have no power to give advisory opinions. ${ }^{60}$

He then listed a number of different interpretive principles "under which [the Court] has avoided passing upon a large part of all the constitutional questions pressed upon it for decision." 61 Modern avoidance was one of those principles. ${ }^{62}$

We can now provide a fairly comprehensive account of the conventional justification for modern avoidance. The combination of classical avoidance, Delaware $\mathcal{E} \mathcal{F}^{2}$ Hudson, and Ashwander yields the following:

(1) In keeping with their oath to uphold the Constitution, members of Congress are presumed to have intended to legislate within constitutional limits. As faithful agents of the legislature, the federal courts are obliged to honor that legislative intent. ${ }^{63}$

a court simply to skip ahead to the question whether the law clearly established that the officer's conduct was unlawful in the circumstances of the case.

Saucier v. Katz, 533 U.S. 194, 201 (2001) (citation omitted). If it does not exceed a federal court's Article IIl authority to address the constitutional merits before the immunity question in a qualified immunity case, then surely it is also within that authority for a court to determine that its otherwise preferred reading of a statute would be unconstitutional before opting instead for an alternative reading. At most, then, Delaware $\mathcal{F}^{\mathrm{H}}$ Hudson identified the kind of "advisory opinions" that courts are reluctant to provide as a matter of prudence, not the kind that they are barred from rendering as a matter of constitutional authority. Cf. Evan Tsen Lee, Deconstitutionalizing Justiciability: The Example of Mootness, 105 Harv. L. Rev. 605, 644-45 (1992) (explaining that Supreme Court has used "advisory opinion" to denote at least five different things, only two of which entail a "constitutional bar").

59. See, e.g., Three Affiliated Tribes v. Wold Eng'g, P.C., 467 U.S. 138, 157 (1984) (describing avoidance of constitutional questions as "a fundamental rule of judicial restraint").

60. 297 U.S. 288, 345-46 (1936) (Brandeis, J., concurring) (footnote omitted) (quoting Adkins v. Children's Hosp., 261 U.S. 525, 544 (1923)).

61. Id. at 346 . For a general discussion of the values underlying Justice Brandeis's interpretive principles, see Thomas Healy, The Rise of Unnecessary Constitutional Rulings, 83 N.C. L. Rev. 847, 921-27 (2005).

62. Ashwander, 297 U.S. at 348 (Brandeis, J., concurring).

63. See Kelley, supra note 26, at 845-46 (describing avoidance in terms of faithful agent theory of statutory interpretation). For a historical defense of the faithful agent 
(2) The values of legislative supremacy and judicial restraint, including the interest in mitigating countermajoritarian concerns, direct the courts to avoid, when possible, passing on the constitutionality of federal statutes.

(3) Although the countermajoritarian difficulty is at its most acute when a court actually invalidates a statute as unconstitutional, the avoidance canon cannot be limited only to those circumstances without requiring the courts to offer advisory opinions on constitutional issues.

I call this the "judicial restraint theory" of modern avoidance, as its critical components (especially those that justify the move from classical to modern avoidance) reflect considerations specific to the federal judiciary.

The most important point here is that the judicial restraint theory of modern avoidance did not emerge on the basis of a presumption that Congress intends to avoid serious constitutional doubts when legislating. In theory, one could try to construct an account of modern avoidance that is based on such a presumption, and some contemporary judicial opinions $^{64}$ and scholarly commentaries ${ }^{65}$ appear to proceed along those lines. But the most historically accurate account of the move from classical avoidance to the judicial restraint theory of modern avoidance does not include a presumption of congressional intent to avoid constitutional doubts. Instead, the judicial restraint theory is best understood to proceed from an assumption that Congress intends to avoid passing only

theory, see John F. Manning, Textualism and the Equity of the Statute, 101 Colum. L. Rev. 1, 56-105 (2001). Professor Manning accompanies this defense with an argument that a textualist interpretive approach provides the best means of implementing the faithful agent model. See id. at 15-22. Of course, that is not the only account of statutory interpretation. William Eskridge, for example, has responded to Professor Manning by arguing that judges engaged in statutory interpretation are "both agents carrying out directives laid down by the legislature and partners in the enterprise of law elaboration," the latter of which might entail construing statutes to achieve equitable results not specifically dictated by the text of the statute. Eskridge, All About Words, supra note 54, at 992. For Professor Manning's reply, see John F. Manning, Deriving Rules of Statutory Interpretation from the Constitution, 101 Colum. L. Rev. 1648 (2001). Such debates, while important, are beyond the scope of this Article. For present purposes, it suffices to observe that the conventional justification of classical avoidance tends to invoke a faithful agent theory as described in the text.

64. See, e.g., Clark v. Martinez, 543 U.S. 371, 381 (2005) (describing modern version of avoidance as "a tool for choosing between competing plausible interpretations of a statutory text, resting on the reasonable presumption that Congress did not intend the alternative which raises serious constitutional doubts"); INS v. St. Cyr, 533 U.S. 289, 336 (2001) (Scalia, J., dissenting) ("The doctrine of constitutional doubt is meant to effectuate, not to subvert, congressional intent, by giving ambiguous provisions a meaning that will avoid constitutional peril, and that will conform with Congress's presumed intent not to enact measures of dubious validity.").

65. Professor Kelley, for example, contends that the avoidance canon "wrongly assumes that Congress legislates without ever intending to approach the limits of the Constitution." Kelley, supra note 26, at 898 . 
those laws that would be actually unconstitutional (reflected in point (1) above). ${ }^{66}$ Beyond that, cases like Delaware $\mathcal{E}^{2}$ Hudson and Ashwander instruct courts also to avoid constitutionally doubtful constructions not out of fidelity to congressional intent, but because of judicial restraint and advisory opinion concerns (reflected in points (2) and (3) above).

In short, the judicial restraint theory casts modern avoidance as an attempt to implement the presumed congressional intent underlying classical avoidance in a manner consistent with the institutional limitations of the federal judiciary.

\section{B. Leading Criticisms of Modern Avoidance}

Although the courts have enshrined avoidance ${ }^{67}$ as a " 'cardinal principle' of statutory interpretation," 68 recent scholarship has launched a number of attacks on the canon. Some critics stress the courts' abuse of the avoidance canon. They point to inconsistencies in its application, and argue that courts tend either to overuse avoidance (by invoking it in the absence of genuine statutory ambiguity or in the service of an implausible constitutional concern) or to underuse it (by failing to apply the canon even in the face of genuine statutory ambiguity and serious constitutional concerns) depending on what best serves the courts' own policy preferences. ${ }^{69}$ Concerns of this sort are certainly legitimate, and I take them up in an analogous context when discussing executive abuse of avoidance. ${ }^{70}$ I want to concentrate here, though, on more fundamental criticisms that focus not on the misapplication of the avoidance canon, but on the basic theoretical premises of the canon itself. In doing so, I aim to highlight certain features of the conventional justification of mod-

66. Indeed, in the typical modern avoidance case, the only reference to congressional intent is to Congress's presumed intent not to violate the Constitution-that is, to the presumed intent animating classical avoidance. See, e.g., Edward J. DeBartolo Corp. v. Fla. Gulf Coast Bldg. \& Constr. Trades Council, 485 U.S. 568, 575 (1988) ("The courts will therefore not lightly assume that Congress intended to infringe constitutionally protected liberties or usurp power constitutionally forbidden it.").

67. From this point on in the Article, unless otherwise specified, all references to the avoidance canon-whether as "modern avoidance" or just "avoidance"-are intended to refer to modern avoidance, which is the more expansive and, in contemporary practice, more commonly invoked form of avoidance.

68. Zadvydas v. Davis, 533 U.S. 678, 689 (2001) (quoting Crowell v. Benson, 285 U.S. 22, 62 (1932)).

69. See Philip P. Frickey, Getting from Joe to Gene (McCarthy): The Avoidance Canon, Legal Process Theory, and Narrowing Statutory Interpretation in the Early Warren Court, 93 Cal. L. Rev. 397, 463 (2005) ("Recent critics of the avoidance canon and related techniques have focused on a few recent cases that might have been poor choices for the use of the canon or in which the canon was poorly implemented."); James J. Brudney \& Corey Ditslear, Canons of Construction and the Elusive Quest for Neutral Reasoning, 58 Vand. L. Rev. 1, 6 (2005) (reporting results of empirical study showing that "canon usage by Justices identified as liberals tends to be linked to liberal outcomes, and canon reliance by conservative Justices to be associated with conservative outcomes").

70. See infra Part III.D. 
ern avoidance (discussed above in Part 11.A) and to set the stage for an alternative justification (discussed below in Part II.C).

Two criticisms of the avoidance canon are most common. First, critics have argued that modern avoidance often conflicts with congressional intent. As Professor Schauer has argued, "in interpreting statutes so as to avoid 'unnecessary' constitutional decisions, the Court frequently interprets a statute in ways that its drafters did not anticipate, and, constitutional questions aside, in ways that its drafters may not have preferred."71 Extending the point, Professor Mashaw suggests that if the choice is between departing from Congress's intended meaning in order to avoid constitutional concerns and simply addressing head-on any concerns raised by the intended meaning, Congress may well prefer the latter even if it would result in the statute's invalidation. ${ }^{72}$ One need not go that far, however, since a court could forsake the modern avoidance canon but retain its classical ancestor. As Judge Friendly explained, if a court concludes that the otherwise best reading of a statute raises serious constitutional doubts, the rational legislator would likely prefer a court to run those doubts to ground:

[T] here is always the chance . . . that the doubts will be settled favorably, and if they are not, the conceded rule of construing to avoid unconstitutionality [that is, classical avoidance] will come into operation and save the day. People in such a heads-1win, tails-you-lose position do not readily sacrifice it $\ldots .{ }^{73}$

Ernest Young is right to observe that Judge Friendly's criticism "surely undermine[s] fidelity to congressional intent as an argument for the [modern] avoidance canon."74 Yet in light of the discussion above in Part Il.A, the criticism might also seem like something of a non sequitur. As that discussion showed, although the justification for classical avoid-

71. Frederick Schauer, Ashwander Revisited, 1995 Sup. Ct. Rev. 71, 74.

72. See Jerry L. Mashaw, Greed, Chaos, and Governance: Using Public Choice to Improve Public Law 105 (1997) (arguing that a "truly restrained court . . . would do better to confront the constitutional question head on" because "even if [the Court] invalidates the law, it at least returns the legislature to the status quo ante and gives the legislature a more realistic chance of concocting a constitutional policy that is close to its mostpreferred position").

73. Henry J. Friendly, Mr. Justice Frankfurter and the Reading of Statutes, in Felix Frankfurter, the Judge 30, 44 (Wallace Mendelson ed., 1964), reprinted in Henry J. Friendly, Benchmarks 196, 210 (1967)

74. Young, supra note 44, at 1581 (emphasis omitted). Note, though, that Judge Friendly's criticism depends on not taking seriously-as many critics of modern avoidance do not-the concern expressed in Delaware $\mathcal{E}$ Hudson that classical avoidance yields advisory opinions. That is, if a court faced with the situation described by Judge Friendly were to eschew modern avoidance and avoid what Delaware $\mathcal{E}$ Hudson deems an advisory opinion, then after concluding that its otherwise preferred reading is unconstitutional, it would adhere to that reading and hold the statute unconstitutional. The court would not even apply classical avoidance. And if Congress knew that courts would proceed along those lines, it would not legislate from a "heads-I-win, tails-you-lose position." In that circumstance, Judge Friendly's claim that modern avoidance disregards legislative intent would be less strong. 
ance depends heavily on fidelity to congressional intent, the extension to modern avoidance does not. Starting in Delaware $\mathcal{F}^{2}$ Hudson, the Court embraced modern avoidance in order to keep the courts within their proper role, not in order to track any presumed congressional intent to avoid constitutional questions. ${ }^{75}$ Still, the judicial restraint theory of modern avoidance does stress the importance of respect for legislative supremacy more generally. ${ }^{76}$ To the extent the judicial use of modern avoidance disregards legislative intent, it would appear to conflict with that value.

The second familiar criticism of the avoidance canon is that it does not, in fact, avoid the unnecessary making of constitutional law. As Professor Schauer has explained, "the Court will [use the avoidance canon to] supplant the otherwise best result only when it believes that there is a serious or substantial constitutional question involved. Yet this determination is itself a confrontation with the very issue that Ashwander seeks to avoid." 77 The point should not be overstated; there is an important difference between determining that a particular constitutional issue is serious and actually resolving it. ${ }^{78}$ Still, in a case where the avoidance canon makes a difference, the court does engage the constitutional issue enough to supplant its otherwise preferred construction of the statute. And because that supplanting can happen by virtue of a constitutional doubt that is ultimately unavailing, the avoidance canon "thwarts Congress's intent in a larger set of cases than would a practice of deciding all constitutional questions on the merits."79 Indeed, Judge Posner goes so far as to contend that the avoidance canon creates a "judge-made constitutional 'penumbra' that has much the same prohibitory effect as the ... Constitution itself." 80 ln short, this second criticism of avoidance asserts that, far from avoiding difficult constitutional questions, courts applying the canon actually overenforce the Constitution.

More recently, William Kelley has mounted an entirely new criticism of the avoidance canon. ${ }^{81}$ Whereas the two criticisms discussed above charge that the avoidance canon fails on its own terms-by disrespecting the legislative supremacy it is supposed to serve, and by overenforcing the Constitution it is supposed to avoid-Professor Kelley's argument is that

75. See supra text accompanying notes 54-57, 60-66.

76. See supra text accompanying notes 63-64.

77. Schauer, supra note 71 , at 87 . On a related note, Emily Sherwin has criticized the avoidance canon and similar techniques for "obscur[ingl the full consequences of judicial review by purporting to be modest when, in fact, they result in new, judicially created rules." Emily Sherwin, Rules and Judicial Review, 6 Legal Theory 299, 321 (2000). In part because she thinks legislatures are better than courts at establishing legal rules, Professor Sherwin favors abandoning the avoidance canon and other similar interpretive tools. Id.

78. See Vermeule, supra note 42, at 1956 n.66.

79. Young, supra note 44, at 1582.

80. Richard A. Posner, Statutory Interpretation-in the Classroom and in the Courtroom, 50 U. Chi. L. Rev. 800, 816 (1983).

81. See Kelley, supra note 26. 
avoidance presents a "three-branch problem." ${ }^{2}$ Specifically, he contends that the avoidance canon creates a conflict between the judicial and executive branches. ${ }^{83}$ The idea here is that the President has the constitutional authority to interpret the laws he is charged with executing. When a court sets aside the executive branch's interpretation on avoidance grounds, it "disregards Executive judgments as to how to discharge the power and duty to take care that the laws be faithfully executed." ${ }^{4}$ And the court does so "not because the statute is unconstitutional but because it is not clearly constitutional." ${ }^{85}$ According to Professor Kelley, that amounts to a constitutionally unauthorized interference with the executive function. Indeed, he argues that the avoidance canon takes the courts well beyond their proper role and "effectively place[s] [them] in the shoes of the President as the law executor in our constitutional system." 86

I alluded to arguments like Professor Kelley's in Part I when I showed that the normative status of executive uses of avoidance depends on whether the values underlying the canon apply to the executive branch. ${ }^{87}$ Applied here, that same basic point reveals that Professor Kelley's argument against avoidance in the courts is strongest if there is no independent reason for the executive branch to employ avoidance. In that circumstance, the executive branch is effectively being told that unless it employs an institutionally inappropriate interpretive tool, it is likely to be reversed. Whether or not one fully agrees with Professor Kelley's assertion that this would constitute an impermissible intrusion on the executive's constitutionally prescribed role, it is clear that the impact on the executive branch is greater in this scenario than it would be if the avoidance canon applied in the executive branch of its own force. As noted in Part I, the latter scenario would not involve the kind of methodological imperialism at work in the former. ${ }^{88}$

Assessing the strength of Professor Kelley's argument thus requires determining whether executive actors should employ avoidance. As its name suggests, the above-described judicial restraint theory does not provide much of a basis for nonjudicial actors to apply the avoidance canon. I will elaborate on that point in Part III, but first we need to consider whether modern avoidance might be justified on alternative grounds.

82. Id. at 831 .

83. Id. at $867-98$.

84. Id. at 898 ; see id. at 834 ("When the Court refuses to credit the Executive's reading of a statute in the name of avoiding the resolution of a serious constitutional question, it threatens to displace the President in his discharge of his constitutional duty to 'take Care that the Laws be faithfully executed.' (quoting U.S. Const. art. 11, § 3)) .

85 . Id. at 868 .

86 . Id. at 898 .

87. See supra text accompanying notes 25-27.

88. See supra text accompanying notes 24-25. 


\section{An Alternative Theory of Modern Avoidance: Constitutional Enforcement}

Although the most common accounts of modern avoidance proceed along the lines of the judicial restraint theory discussed above, the judicial and scholarly literatures also provide an alternative account. 89 One of the most detailed elaborations of that account is found in Ernest Young's work on "resistance norms." 90 According to Professor Young, the avoidance canon should be viewed as "designed not to reflect what Congress might have wanted under particular conditions, but rather to give voice to certain normative values." ${ }^{11}$ ln any given case implicating the avoidance canon, those values "are simply those embodied in the underlying constitutional provisions that create the constitutional 'doubt." "92 When implemented by means of avoidance, those constitutional provisions do not dictate the invalidation of the legislation in the mode of conventional judicial review. Instead, they operate as resistance norms-constitutionally grounded "rules that raise obstacles to particular governmental actions without barring those actions entirely."93

On this account, the overarching norm implemented by the avoidance canon is that if Congress wants to legislate to the limits of its constitutional authority or in a manner that otherwise raises serious constitutional concerns, it must be clear about its intent to do so. This "constitutional enforcement theory" of avoidance echoes a description offered by William Eskridge some years earlier. As he explained, the avoidance canon "makes it harder for Congress to enact constitutionally questionable statutes and forces legislators to reflect and deliberate before plunging into constitutionally sensitive issues." 94

Understood in constitutional enforcement terms, the avoidance canon is relatively impervious to the first two criticisms discussed above. ${ }^{95}$ First, if the aim of avoidance is to protect constitutional values by effectively "rais[ing] the cost of any congressional encroachment within a particular area of constitutional sensitivity," then its failure to track congres-

89. Professor Kelley acknowledges the theoretical possibility of "attempt[ing] to defend the [modern avoidance] canon ... by arguing that [it] is simply part of the judicial power to adopt policy-based norms of litigation," but he claims that "[n] either the courts nor commentators have offered such a defense." Kelley, supra note 26, at 845 n.97. Instead, he contends that "the Court has conceived and justified the avoidance canon based upon a faithful agent theory of statutory interpretation grounded in legislative supremacy, and that commentators have generally analyzed the canon on those terms." Id. (emphasis omitted). As this subsection shows, that claim overlooks the fact that courts and commentators alike have offered an alternative understanding of the avoidance canon as advancing substantive norms not confined to a faithfuI agent theory of interpretation.

90. See Young, supra note 44.

91. Id. at $\mathbf{1 5 8 5}$.

92. Id. at $155 \mathrm{I}$.

93. Id. at 1585. Philip Frickey has recently provided a similar defense of avoidance, which he terms a "normative defense." See Frickey, supra note 69, at 450-55.

94. Eskridge, Dynamic Statutory Interpretation, supra note 40, at 286.

95. See supra text accompanying notes 71-80. 
sional intent is largely irrelevant. ${ }^{96}$ The constitutional enforcement theory, in other words, simply does not view the avoidance canon in faithful agent terms. Second, since the enforcement theory views the avoidance canon as reflecting constitutional commitments, ${ }^{97}$ Judge Posner's complaint that avoidance creates a penumbral Constitution ${ }^{98}$ hecomes just a restatement of the canon's point, not an indictment of it. ${ }^{99}$

The closest analogs to the constitutional enforcement theory of avoidance are the Supreme Court's various "clear statement" rules. In its federalism cases, for example, the Court has fashioned a number of interpretive rules that impede, but do not prohibit, federal encroachment on the states. In Gregory v. Ashcroft, the Court held that in order for Congress to regulate core state governmental functions pursuant to its Commerce Clause authority, it must provide a clear statement of its intent to do so in the language of the statute. ${ }^{100}$ And in Atascadero State Hospital v. Scanlon, the Court instructed that although Congress has the authority under Section 5 of the Fourteenth Amendment to abrogate states' Eleventh Amendment immunity from suit in federal court, it may abrogate that immunity "only by making its intention unmistakably clear in the language of the statute." ${ }^{101}$ Clear statement rules of this sort do not necessarily involve application of the avoidance canon itself, since in some cases it may be clear that Congress has the constitutional authority to pass the legislation in question. ${ }^{102}$ But possessing the authority is not enough; Congress must also be clear about its intent to exercise the authority. ${ }^{103}$

The Court has developed and applied clear statement rules most aggressively in areas involving judicially "underenforced constitutional norms"-constitutionally derived norms that the courts are not well positioned to enforce directly. ${ }^{104}$ For example, to the extent there is a consti-

96. Young, supra note 44 , at 1606 (emphasis omitted).

97. See Cass R. Sunstein, Nondelegation Canons, 67 U. Chi. L. Rev. 315, 338 (2000) [hereinafter Sunstein, Nondelegation Canons] (describing avoidance canon as one of several "nondelegation principles ... designed to ensure that Congress decides certain contested questions on its own," and asserting that "[i]f this idea is a core structural commitment of the Constitution, there can be no problem with its judicial enforcement").

98. See Posner, supra note 80 , at 816.

99. See Eskridge, Dynamic Statutory Interpretation, supra note 40, at 287; Frickey, supra note 69, at 450; Young, supra note 44 , at 1598 .

100. 501 U.S. 452, 460-64 (1991).

101. 473 U.S. 234, 242 (1985). For a discussion of other federalism-related clear statement rules, see Eskridge et al., supra note 6, at 367-75.

102. Such is the case for the Atascadero rule. See Atascadero, 473 U.S. at 242-43 ("Congress may, in determining what is "appropriate legislation" for the purpose of enforcing the provisions of the Fourteenth Amendment, provide for private suits against States or state officials which are constitutionally impermissible in other contexts." (quoting Fitzpatrick v. Bitzer, 427 U.S. 445, 456 (1976))).

103. See EEOC v. Arabian Am. Oil Co., 499 U.S. 244, 262 (1991) (Marshall, J., dissenting) ("Clear-statement rules operate less to reveal actual congressional intent than to shield important values from an insufficiently strong legislative intent to displace them.").

104. See generally Sager, supra note 37 (arguing that constitutional norms not fully enforced by federal judiciary remain valid despite institutional enforcement concerns). 
tutional norm against congressional encroachment on core state governmental functions, the Court in Garcia $v$. San Antonio Metropolitan Transit Authority concluded it was not susceptible to direct judicial enforcement. ${ }^{105}$ After Garcia, however, the Court articulated its Gregory clear statement rule and erected what amounts to a federalism-enhancing resistance norm. In this way, clear statement rules are statutory means of protecting otherwise underenforced constitutional values. ${ }^{106}$

The constitutional enforcement theory of avoidance often proceeds in similar fashion. Indeed, a number of commentators refer to the avoidance canon as a clear statement rule. Professor Eskridge, for example, calls avoidance a "constitutionally based clear statement rule[ ]" that provides a "subconstitutional way to enforce 'underenforced' constitutional norms." 107 The Supreme Court has occasionally described avoidance in comparable terms, ${ }^{108}$ and it has applied a clear statement version of tbe canon in a number of areas where the underlying constitutional interest tends to be judicially underenforced. In national security and foreign affairs, for example, the Court typically requires a clear statement before it will construe a statute to intrude, perhaps unconstitutionally, upon the Article $\mathrm{Il}$ prerogatives of the executive branch. ${ }^{109}$

In addition, and of particular interest for purposes of this Article, the Court has applied a clear statement version of avoidance in cases involv-

105. 469 U.S. $528,546-47$ (1985).

106. See generally Eskridge \& Frickey, Quasi-Constitutional Law, supra note 9 (discussing and questioning super-strong clear statement rules).

107. Eskridge, Dynamic Statutory Interpretation, supra note 40, at 286; see also Stephen G. Breyer et al., Administrative Law and Regulatory Policy: Problems, Text, and Cases 327 (6th ed. 2006) (referring to " $t$ t] he principle that statutes will be construed so as to avoid serious constitutional doubts [as a] clear statement principle").

108. See, e.g., Gonzales v. Oregon, 126 S. Ct. 904, 935 (2006) (Scalia, J., dissenting) (referring to avoidance canon as occupying one "line of our clear-statement cases"); Zadvydas v. Davis, 533 U.S. 678, 689, 696-97 (2001) (describing avoidance canon in nonclear statement terms, but then employing avoidance to read implicit time limitation into alien-detention provision at issue, and justifying that application by saying that if Congress intended to rule out such limitation, "it certainly could have spoken in clearer terms"); NLRB v. Catholic Bishop, 440 U.S. 490, 501 (1979) (describing avoidance canon as directing courts to avoid "serious constitutional questions" in absence of "affirmative intention of the Congress clearly expressed" (internal quotation marks omitted) (quoting McCulloch v. Sociedad Nacional de Marineros, 372 U.S. 10, 22 (1963))).

109. See, e.g., Dep't of the Navy v. Egan, 484 U.S. 518, 530 (1988) ('[U]nless Congress specifically has provided otherwise, courts traditionally have been reluctant to intrude upon the authority of the Executive in military and national security affairs."). Professor Eskridge describes the rule bere as a "[s] uper-strong rule against congressional interference with the president's authority over foreign affairs and national security," independent of the general avoidance canon. Eskridge, Dynamic Statutory lnterpretation, supra note 40 , at 325 . 1 agree that the clear statement requirement in these areas is "superstrong," but for present purposes $1 \mathrm{am}$ content to see it as one particularly robust application of the avoidance canon rather than an independent canon unto itself. This question of categorization, however, is largely aesthetic; 1 don't think anything substantive turns on it. 
ing challenges to agencies' interpretations of statutes. ${ }^{110}$ The principle here, as Cass Sunstein explains, is that:

constitutionally sensitive questions . . . will not be permitted to arise unless the constitutionally designated lawmaker has deliberately and expressly chosen to raise them. ... So long as the statute is unclear, and the constitutional question serious, Congress must decide to raise that question via explicit statement. . . Executive interpretation of a vague statute is not enough when the purpose of the canon is to require Congress to make its instructions clear. ${ }^{111}$

Viewed this way, the constitutional enforcement theory of avoidance fits quite comfortably within the broader family of clear statement rules crafted by the Supreme Court.

Two caveats are in order here, however. First, although the constitutional enforcement theory can be conceived as a means of implementing indirectly certain constitutional norms that the courts tend to underenforce directly, it need not be confined to underenforced norms. The enforcement theory posits avoidance as a statutory means of implementing constitutional values. The need for such implementation may be particularly great where the underlying value enjoys little direct enforcement, but the enforcement theory can also support avoidance across the board. Professor Sunstein's above-quoted account of avoidance, for example, does not depend on the constitutional norm being underenforced. Rather, it provides that, in the absence of clear instructions from Congress, courts should not allow agencies to construe statutes to trigger any "constitutionally sensitive questions." 112 Understood this way, the constitutional enforcement theory contemplates that every constitutional provision is protected by both whatever direct means are available to the courts and the indirect means of the avoidance canon.

Second, although enforcement-based accounts of avoidance do sometimes depict it as a clear statement rule, ${ }^{13}$ the standard description of avoidance does not require a true clear statement in order to force the doubts-raising construction. ${ }^{114}$ 1nstead, it instructs that if the conven-

110. See, e.g., Solid Waste Agency v. U.S. Army Corps of Eng'rs, 531 U.S. 159, 172 (2001) ("Where an administrative interpretation of a statute invokes the outer limits of Congress' power, we expect a clear indication that Congress intended that result.").

111. Sunstein, Nondelegation Canons, supra note 97 , at 331 .

112. Id.

113. See cases cited supra notes 108-110.

114. Again, the standard statement of the avoidance rule, which $I$ have set forth in various places above, is that "where an otherwise acceptable construction of a statute would raise serious constitutional problems, the Court will construe the statute to avoid such problems unless such construction is plainly contrary to the intent of Congress." Edward J. DeBartolo Corp. v. Fla. Gulf Coast Bldg. \& Constr. Trades Council, 485 U.S. 568, 575 (1988); see also, e.g., Solid Waste Agency, 531 U.S. at 173 (quoting Edward J. DeBartolo Corp. to state the standard avoidance rule); Reno v. ACLU, 521 U.S. 844, 892 (1997) (O'Connor, $\mathrm{J}$., concurring in the judgment in part and dissenting in part) (same); United States v. Winstar Corp., 518 U.S. 839, 875 (1996) (same); Concrete Pipe \& Prods. of Cal., Inc. v. 
tional tools of statutory interpretation "pretty clearly point to a preferred construction," 115 the court should adopt that construction and then address any constitutional doubts head-on. Doing so is consistent with the spirit of the Supreme Court's oft-repeated injunction that when employing the canon, courts "cannot press statutory construction 'to the point of disingenuous evasion' even to avoid a constitutional question." 116 On occasion, however, the Court has described avoidance in more clear statement terms by stating, for example, that a doubts-raising construction should be avoided unless it is compelled by "the affirmative intention of the Congress clearly expressed." 117 Under such a standard, it is not enough for ordinary tools of statutory interpretation to point steadily in the direction of the doubts-raising interpretation. Only if that interpretation is dictated by a specific and explicit textual statement should it be adopted. Obviously, this version of avoidance is much more robust than the more conventional version. That is, the underlying constitutional value receives much greater protection under the clear statement version than under the conventional version. It is not my goal here to choose between the two versions, but simply to note the difference. The significance of the difference will emerge again in Part IV. ${ }^{118}$

With or without a full clear statement requirement, the bottom line is that the constitutional enforcement theory is driven neither by a faithful agent account of statutory interpretation nor by concerns about the institutional limitations of the judiciary. Instead, the constitutional enforcement theory sees avoidance as protecting constitutional values by making it more difficult for Congress to encroach on those values. Put another way, the constitutional enforcement theory sees the avoidance canon as a means of communication between the courts and Congress. By construing a statute to avoid certain constitutional concerns, the courts tell Congress that if it wishes to reach further, it must return to the legislative process and clarify its intended meaning. ${ }^{119}$

Constr. Laborers Pension Trust, 508 U.S. 602, 628-29 (1993) (same); New York v. United States, 505 U.S. 144, 170 (1992) (same); Burns v. United States, 501 U.S. 129, 138 (1991) (same); Rust v. Sullivan, 500 U.S. 173, 223 (1991) (O'Connor, J., dissenting) (same).

115. Eskridge et al., supra note 6 , at 367 (emphasis added).

116. United States v. Locke, 471 U.S. 84, 96 (1985) (quoting Moore Ice Cream Co. v. Rose, 289 U.S. 373, 379 (1933)).

117. NLRB v. Catholic Bishop, 440 U.S. 490, 501 (1979) (emphasis added) (internal quotation marks omitted) (quoting McCulloch v. Sociedad Nacional de Marineros, 372 U.S. 10, 22 (1963)).

118. See infra text accompanying notes $230-231$.

119. See Eskridge, Dynamic Statutory Interpretation, supra note 40, at 286 (observing that avoidance "makes it harder for Congress to enact constitutionally questionable statutes and forces legislators to reflect and deliberate before plunging into constitutionally sensitive issues"). I return to this idea of the avoidance canon as an instrument of congressional notification in Part III.E, infra. 
$* \quad * \quad *$

In this section, I have identified two theories of the modern avoidance canon. The more commonly recited is the judicial restraint theory, which blends a presumption about congressional intent (that Congress did not intend to enact unconstitutional legislation) with institutionally specific concerns about the judiciary (that courts should avoid rendering advisory opinions and should limit their countermajoritarian effects). ${ }^{120}$ The constitutional enforcement theory, in contrast, is not motivated by congressional intent or countermajoritarianism. ${ }^{121}$ Instead, it is concerned with constraining the legislature. The underlying idea is that as Congress approaches constitutional boundaries, it activates a constitutional interest in keeping government within those boundaries. The avoidance canon, on this view, guards the boundaries by making it more difficult for Congress even to approach them.

Because it is not principally about tracking congressional intent or limiting the judicial role, the constitutional enforcement theory is largely immune from the first two criticisms of the avoidance canon identified in Part 1I.B. Whether it survives the third criticism-Professor Kelley's argument that judicial use of avoidance unduly intrudes upon executive prerogatives ${ }^{122}$-depends, in part, on whether the constitutional enforcement theory supports avoidance in the executive branch itself. 1 now turn to that question.

\section{The Avoidance Canon in the Executive Branch: APPLYING THE THEORIES}

It should be clear by now that to evaluate an interpretive rule like the avoidance canon is to consider the values-especially the constitutional values-it serves, or disserves. In Part II, I identified two separate theories of modern avoidance, each reflecting different constitutional values. ${ }^{123}$ Both theories typically proceed on the assumption that the interpretation in question will happen in a court; they are theories for why judges should apply the avoidance canon. In this section, I move to the executive branch. I begin with a brief survey of executive practice, the main point of which is to note that although executive actors often employ the avoidance canon, they rarely establish a theoretical basis for doing so. I then seek to fill that gap by considering whether either theory of avoidance discussed in Part II supports its application in the executive branch. I show that the judicial restraint theory does not fit the executive branch, but that the constitutional enforcement theory can fit there. From there, I identify two potential concerns-self-dealing and abuseand explain why neither should affect the general legitimacy of avoidance

120. See supra Part II.A.

121. See supra Part II.C.

122. See supra text accompanying notes 81-88.

123. See supra Parts II.A, II.C. 
in the executive branch. Finally, I conclude the section by underscoring a critical premise of the constitutional enforcement theory-that Congress is notified when the avoidance canon has been employed to narrow one of its statutes. To the extent the executive would embrace the constitutional enforcement theory, its use of avoidance must satisfy that premise.

\section{A. The Executive's Use of Avoidance in Practice}

Although its use is not uniform across the executive branch, the avoidance canon appears fairly often in the work of at least some executive components. A quick survey of the Federal Register reveals a modest number of agency invocations of avoidance when explaining new rules or actions. ${ }^{124}$ The Federal Communications Commission, for example, has on several occasions acknowledged "an obligation under Supreme Court precedent to construe a statute "where fairly possible to avoid substantial constitutional questions.' "125 Other than the statement that Supreme Court precedent obliges the agency to employ avoidance, however, these pronouncements contain no discussion of the basis for the canon. Other agencies have invoked avoidance in similarly summary fashion. ${ }^{126}$

A similar pattern emerges in the legal opinions of the Justice Department's Office of Legal Counsel (OLC). ${ }^{127}$ The avoidance canon appears

124. A July 9, 2006 Westlaw search of the Federal Register (fr) database for the terms "constitution! /s avoid /s (doubt concern question problem)" produced 28 hits, about one-half of which involve the application of the avoidance canon or at least the acknowledgement of its general validity in that context.

125. Implementation of the Non-Accounting Safeguards of Sections 271 and 272 of the Communications Act of 1934, as Amended, 62 Fed. Reg. 2927, 2958 (Jan. 21, 1997) (quoting United States v. X-Citement Video, 513 U.S. 64, 69 (1994)); see also, e.g., Implementation of the Telecommunications Act of 1996: Telemessaging, Electronic Publishing, and Alarm Monitoring Services, 62 Fed. Reg. I6,093, 16,095 (Apr. 4, 1997) (acknowledging same obligation); Cross-Ownership Rules, 60 Fed. Reg. 31,924, 31,925 (Jun. 19, 1995) (same).

126. See, e.g., Standards for Business Practices of Interstate Natural Gas Pipelines, 67 Fed. Reg. 49,564, 49,567 n.17 (Fed. Energy Regulatory Comm'n July 31, 2002) (citing but not discussing Concrete Pipe \& Products of California, Inc. v. Construction Laborers Pension Trust, 508 U.S. 602, 629 (1993), for proposition that "statutes are to be construed to avoid serious doubt of their constitutionality"); Political Activities of Federal Employees, 59 Fed. Reg. 48,765, 48,767 (Office of Pers. Mgmt. Sept. 23, 1994) (" "[I]f the amendments to the Hatch Act were interpreted to prevent an Administration from directing the political activities of even its high-level political appointees, the amendments would raise serious constitutional questions. . . The amendments should be interpreted in a manner that avoids these serious constitutional issues.' (quoting Letter from Walter Dellinger, Assistant Attorney Gen., Office of Legal Counsel, to Lorraine P. Lewis, Gen. Counsel, Office of Pers. Mgmt. (Sept. 20, I994))).

127. This opinion function is statutorily vested in the Attorney General, who "shall give his advice and opinion on questions of law when required by the President," and who must also provide advice to department heads, when asked, "on questions of law arising in the administration of [their] department[s]." 28 U.S.C. $\$ \$ 51$ I-512 (2000). The Attorney General has, in turn, delegated that authority to OLC. See 28 C.F.R. $\$ 0.25$ (a)-(b) (2005). 
frequently in OLC opinions; like the courts, OLC tends to regard it as a "settled" rule. ${ }^{128}$ Yet to the extent OLC's opinions provide any justification for their use of avoidance, they often simply observe that the canon is a "cardinal principle" of judicial statutory interpretation and then assert without further reasoning that the executive branch should employ it too. ${ }^{129}$ Other opinions do even less, merely citing a leading Supreme Court case on avoidance while silently implying that the basis for the Court's use of the canon-whatever it is-must work just as well in the executive branch. ${ }^{130}$

These practices-both in the agencies and at OLC-are inadequate. The mere citation to a Supreme Court opinion is not enough to justify constitutional avoidance in the executive branch. The Court's avoidance precedents themselves speak only of the circumstances in which courts should use avoidance; by their terms they do not oblige the executive branch to follow suit. To be sure, judicial precedents can be useful to the extent they reveal the values at stake in the choice of interpretive methods. But it is ultimately the values themselves-and the extent of their resonance in the executive branch-that an executive actor should consider when deciding whether to employ avoidance.

Having just criticized OLC's typical treatment of avoidance, 1 should note that its practice in this area is not uniformly lacking. Although most OLC uses of avoidance are not adequately justified, a few opinions contain more nuanced accounts of the canon and its place in the executive

128. Limitations on the Detention Authority of the Immigration and Naturalization Service, Op. Off. Legal Counsel (2003), at http://www.usdoj.gov/olc/INSDetention.htm (on file with the Columbia Law Review) ("It is settled, of course, that where there are two or more plausible constructions of a statute, a construction that raises serious constitutional concerns should be avoided.").

129. Application of 28 U.S.C. $\$ 458$ to Presidential Appointments of Federal Judges, 19 Op. Off. Legal Counsel 350, 352 (1995) ("[1]t is a long-recognized 'cardinal principle' of statutory interpretation that statutes be construed to avoid raising serious constitutional questions. This canon of statutory construction is a cornerstone of judicial restraint .... The canon is equally applicable to executive branch interpretations." (emphasis added) (citations omitted) (quoting Crowell v. Benson, 285 U.S. 22, 62 (1932))); see, e.g., Section 235A of the Immigration and Nationality Act, Op. Off. Legal Counsel (2000), at http://www.usdoj. gov/olc/ina235Anew.htm (on file with the Columbia Law Review) ("Our approach on this point is consistent with the Supreme Court's admonition to interpret statutes so as to avoid constitutional questions where possible."); Presidential Certification Regarding the Provision of Documents to the House of Representatives Under the Mexican Debt Disclosure Act of 1995, 20 Op. Off. Legal Counsel 253, 265 (1996) ("Absent clear evidence of Congress's contrary intent, a court will adopt a reasonable construction of a statute to avoid reaching a serious constitutional problem. The practice of the executive branch is and should be the same." (emphasis added) (footnote omitted)).

130. See, e.g., Designation of Acting Director of the Office of Management and Budget, Op. Off. Legal Counsel 5 (2003), at http://www.usdoj.gov/olc/opinions/0612 2003_ombdirector2.pdf (on file with the Columbia Law Review) ("The principle of constitutional avoidance requires a construction of the statute that removes serious constitutional doubt." (citing Edward J. DeBartolo Corp. v. Florida Gulf Coast Building \& Construction Trades Council, 485 U.S. 568, 575 (1988))). 
branch. I discuss one such opinion in the next subsection, ${ }^{131}$ after reintroducing the two theories of avoidance discussed in Part II.

\section{B. The Avoidance Theories in the Executive Branch}

As I showed in Part II, there are two basic theories of modern avoidance in the courts-the judicial restraint theory ${ }^{132}$ and the constitutional enforcement theory. ${ }^{133}$ My point in this subsection is that the propriety of avoidance in executive branch statutory interpretation depends, first, on which of those two theories one chooses.

Before applying the two theories of modern avoidance to the executive branch, it is useful to recall the distinction between classical and modern avoidance and to consider the status of the former in the executive branch. As discussed above, ${ }^{134}$ the dominant account of classical avoidance is based on a presumption that Congress intends to legislate within constitutional boundaries. That presumption need not be tied to any institutional peculiarities of the judiciary; as a matter of interbranch comity, it is just as appropriate for the executive branch to presume congressional fidelity to the Constitution as it is for the courts to do so. Of course, this does not get us all the way to modern avoidance, which goes beyond avoiding actual unconstitutionality to avoiding constitutional doubts. But it is enough for classical avoidance, whether employed by the courts or the executive. Thus, the dominant account of classical avoidance would appear to work just as well in the executive branch as in the courts. ${ }^{135}$

The main concern of this Article, however, is the more commonly employed modern version of avoidance. Thus, the question here is whether either the judicial restraint or constitutional enforcement theory provides a basis for the executive branch to go beyond classical avoidance and employ modern avoidance as well. ${ }^{136}$

Consider first the judicial restraint theory. The key considerations at work in that theory are the countermajoritarian nature of judicial review, and, relatedly, the need for courts to avoid issuing advisory opinions. ${ }^{137}$

131. See infra text accompanying notes 168-173.

132. See supra Part II.A.

133. See supra Part II.C.

134. See supra text accompanying notes 49-50.

135. This is not to say, of course, that all executive applications of classical avoidance are beyond criticism. Even if classical avoidance is generally appropriate in the executive branch, there is a risk that executive actors might still employ it in circumstances where it should not apply, or fail to use it where it should apply. Thus, the concerns discussed below in Parts III.D and IV are relevant to classical as well as modern avoidance.

136. In other words, the principal alternative to applying modern avoidance in the executive branch is not invalidating the statute as unconstitutional, but fully examining the constitutional concerns attending the executive's preferred reading of the statute and applying classical avoidance when those concerns rise to the level of rendering the reading actually unconstitutional.

137. See supra text accompanying notes 54-58. 
We need not reach a conclusion about the merits of those considerations to see that they have very little purchase outside the federal judiciary. The executive branch does not present the same countermajoritarian concerns as the federal judiciary, ${ }^{138}$ and it is wholly immune from the "case or controversy" limitations (and their prudential extensions) that forbid courts from issuing advisory opinions. Thus, the values at work in the judicial restraint theory cannot justify modern avoidance in the executive branch.

In one of only two sustained scholarly discussions of whether executive actors ought to employ avoidance, Jerry Mashaw appears to embrace the judicial restraint theory. ${ }^{139}$ Describing avoidance as "based on principles of constitutional comity," he suggests that it "[a]rguably" does not apply to agencies:

[A]n administrative apparatus that operated in the shadow of the avoidance canon would set itself up operationally as the arbiter of the constitutionality of congressional action. Administrative avoidance settles the constitutional question. . . . Constitutionally timid administration both compromises faithful agency and potentially usurps the role of the judiciary in harmonizing congressional power and constitutional command. ${ }^{140}$

138. See Chevron U.S.A. Inc. v. Natural Res. Def. Council, Inc., 467 U.S. 837, 864-66 (1984) (noting that administrative agencies are more accountable to democratic process than are courts). As discussed above in note 4, the overwhelming majority of administrative law scholars today agree that administrative agencies are part of the executive branch. Among other things, that placement confers on the administrative state a certain democratic legitimacy by highlighting its answerability to the President. See Bressman, supra note 4, at 1675-78. The point should not be overstated, however, since the degree of presidential control varies substantially throughout the executive branch. See generally Kevin M. Stack, The President's Statutory Powers to Administer the Laws, 106 Colum. L. Rev. 263 (2006) (arguing that President's authority (and therefore legitimate control) under statutory regime depends on whether statute grants power to President in name or to agency head or other actor). In particular, the President's control over independent agencies is much more modest than his control over executive departments. Compare Humphrey's Ex'r v. United States, 295 U.S. 602, 629-30 (1935) (holding President lacks removal power over Federal Trade Commissioner), with Myers v. United States, 272 U.S. 52, 176 (1926) (holding President has removal power over Postmaster General). In light of that variance, it may be appropriate to think of some administrative entities-especially independent agencies-as somewhat countermajoritarian. For that reason, I say only that the executive branch does not present the same countermajoritarian concerns as the entirely unelected federal judiciary, not that the executive branch raises no countermajoritarian concerns at all. But in any event, the other key ingredient of the judicial restraint theory of avoidance-the concern about advisory opinions-has no application in the executive branch.

139. See Mashaw, Paradox of Deference, supra note 2, at 507-09. The other discussion of avoidance in the executive branch is found in H. Jefferson Powell's short essay, The Executive and the Avoidance Canon, supra note 2. I discuss it in Part III.C, infra.

140. Mashaw, Paradox of Deference, supra note 2, at 507-08. 
Aimed at the judicial restraint theory of avoidance, this is a powerful argument. As noted above, ${ }^{141}$ one of the most common arguments against judicial use of the avoidance canon is that it does not track legislative intent and thus disserves legislative supremacy. If that objection has traction against avoidance in the judiciary, it seems all the more forceful as applied to the executive branch: Congress would very likely prefer the executive branch to enforce its legislation according to its best understanding of Congress's intent, and then to let the courts sort out the constitutional issues as needed.

But what if avoidance is instead grounded in the constitutional enforcement theory? Critically, that theory is not premised on fidelity to legislative intent. ${ }^{142}$ Congress may well have intended a statutory meaning that raises substantial constitutional questions, but the constitutional enforcement theory tells Congress that it needs to be clear about that intent before it will be honored. The idea is to "raise [ ] the cost of any congressional encroachment within a particular area of constitutional sensitivity,"143 not simply to play the faithful agent. On these terms, avoidance would seem just as appropriate in the executive branch as in the courts. Indeed, if "the purpose of the canon is to require Congress to make its instructions clear," 144 it is more likely to be effective if it is consistently applied by the executive as well as the courts.

The avoidance canon may be more effective if employed by the executive branch, but would it be legitimate? In particular, what are we to make of Professor Mashaw's argument that constitutional avoidance in the executive branch "potentially usurps the role of the judiciary" by "foreclos[ing] authoritative resolution of constitutional questions by the judiciary"? ${ }^{145}$ There are a number of problems with this argument. First, as a descriptive matter it seems to overlook a significant category of executive branch legal interpretations. As noted above, ${ }^{146}$ many constitutional issues will never come before the courts no matter what the executive does. Much executive statutory interpretation is simply not susceptible to judicial review, or at least not readily so. In those circumstances, executive engagement with the constitutional question-whether by means of the avoidance canon or otherwise-does not affect the judiciary at all. Simply put, Professor Mashaw's argument has no purchase in nonjusticiable cases.

What about cases that do make it to court? As a descriptive matter, is Professor Mashaw right that by narrowly construing a statute in order to avoid a constitutional concern, the executive will effectively disable the courts from considering the constitutionally questionable reading? It de-

141. See supra text accompanying notes 71-73.

142. See supra text accompanying notes 95-96.

143. Young, supra note 44, at 1606 (emphasis omitted).

144. Sunstein, Nondelegation Canons, supra note 97 , at 331.

145. Mashaw, Paradox of Deference, supra note 2, at 508.

146. See supra text accompanying notes 21-22. 
pends. If a broad reading of the statute would implicate an individual right or other legislative power-limiting provision of the Constitution, then Professor Mashaw may well be correct. Having construed the statute narrowly to avoid such a constitutional difficulty, the executive would then implement the statute without implicating the constitutional issue. Thus, there would be no occasion for anyone with standing to raise the issue in a challenge to the statute, and so the courts would be precluded from addressing it. The situation would be different, however, if the statute regulated the executive branch itself in a way that implicated and potentially intruded upon the President's authority under Article 1I. In that circumstance, the executive's use of avoidance would narrow the statute so that it did not limit executive action, thus creating greater latitude within which the executive could act. ${ }^{147}$ After the executive undertook the action in question, a party with standing could challenge the action as both contrary to the statute and unconstitutional. In such a case, the executive's construction of the statute would not insulate the underlying constitutional issue from judicial review; both the statutory and (if necessary) the constitutional issue would be squarely before the court. Thus, the descriptive accuracy of Professor Mashaw's objection depends on the kind of constitutional concern at issue.

Setting descriptive matters to one side, the more important problem with Professor Mashaw's argument is its apparent normative claim that constitutional implementation should belong exclusively, or at least mostly, to the courts. That claim seems to slight the important and independent role of the executive branch in interpreting and enforcing the Constitution. ${ }^{148}$ I turn to that role now.

Enforcing the Constitution is not an exclusively judicial task. The President's oath of office imposes on him a duty to "preserve, protect and defend the Constitution."149 In addition, he is required to "take Care that the Laws be faithfully executed," 150 which entails an obligation to respect both federal statutes and the Constitution. Admittedly, merely recognizing a presidential (and hence executive branch) obligation to enforce the Constitution does not tell us how that obligation is to be discharged. In particular, it does not tell us whether executive actors are obliged to accept Supreme Court precedents as authoritative statements about the Constitution. There is a large and growing academic literature on this subject, containing a wide variety of views. ${ }^{151}$ Much of that literainfra.

I47. I discuss such seIf-protective uses of the avoidance canon at length in Part III.C,

I48. See Peter L. Strauss, The President and Choices Not to Enforce, Law \& Contemp. Probs., Winter/Spring 2000, at 107, I I9 [hereinafter Strauss, Choices] (arguing that "subordinat[ing] the President as a reader of the Constitution and elevat[ing] the judiciary" can be "difficult to justify in a government of co-equal branches").

I49. U.S. Const. art. II, § I, cl. 8.

150. Id. art. II, $\S 3$.

I5I. I cite some of it in note 2, supra, and I discuss some of it in the text accompanying notes $34-39$. 
ture focuses on the question whether the executive branch is free to conclude that certain government actions are consistent with the Constitution, even though the Supreme Court has held (or strongly intimated) otherwise. The competing answers range from claims by commentators like Michael Stokes Paulsen that the President is empowered to disregard the Court's precedents in such circumstances, ${ }^{152}$ to dictum in Cooper $v$. Aaron that when the Court decides a constitutional question, the decision effectively becomes the Constitution itself. ${ }^{153}$ The conventional view, while not going quite so far as Cooper, is that the executive branch is indeed bound by the Supreme Court's determination that a given statute or governmental action is unconstitutional. ${ }^{154}$ Although 1 share that view, it is not germane to my present argument. 1nstead, the obverse question is of greater interest here-whether the President may conclude that a particular law or action is unconstitutional, even though the courts did not, or clearly would not, reach that conclusion. ${ }^{155}$

The best answer, 1 think, is yes. Consider first the matter of political questions and other nonjusticiable issues. As noted above, ${ }^{156}$ executive branch officials may often face constitutional issues that courts would regard as nonjusticiable. Clearly, though, the fact that the courts have essentially no role in implementing certain provisions of the Constitution does not license the executive branch to ignore those provisions. Instead, executive officials have a duty to abide by their own best understanding of the provisions. ${ }^{157}$ Nor is this point confined to issues the courts would regard as literally nonjusticiable. Recall the concept of judicially underenforced constitutional norms, introduced earlier. ${ }^{158}$ Here we are thinking of constitutional norms that may be formally justiciable, but that receive relatively little (or weak) judicial enforcement. As Larry Sager explained in his classic article on underenforced norms, executive

152. See Paulsen, supra note 2, at 221-22.

153. 358 U.S. 1,18 (1958).

154. The majority (though certainly not all) of the sources cited in note 2 , supra, take that position.

155. See Barron, supra note 2, at 69-70 (noting distinction between the two scenarios and asserting that "[e]ven if the President were to consider himself bound to obey a judicial determination that a statute is unconstitutional ... it would not follow that he should understand himself to be similarly bound by a judicial determination that a statute is constitutional").

156. See supra text accompanying notes 21-22, 146.

157. See Trevor W. Morrison, Hamdi's Habeas Puzzle: Suspension as Authorization?, 91 Cornell L. Rev. 411, 436-37 (2006) ("[T]he nonjusticiability of a particular constitutional provision does not render the provision meaningless. 1nstead, the political branches must bind themselves to their best understanding of the provision, without the aid (or interference) of the courts."); Pillard, supra note 2, at 690 ("[A judicial] decision not to invalidate government action on political question grounds is of course very different from a decision that specific congressional action does not violate the Constitution,' because it leaves open the possibility that the political branches might themselves find a violation." (quoting U.S. Dep't of Commerce v. Montana, 503 U.S. 442, 458 (1992)))

158. See supra text accompanying notes $104-106$. 
branch officials "cannot consider themselves free to act at what they perceive or ought to perceive to be peril to constitutional norms merely because the federal judiciary is unable to enforce these norms at their margins."159 Instead, they "have a legal obligation to obey an underenforced constitutional norm which extends beyond its interpretation by the federal judiciary to the full dimensions of the concept which the norm embodies." 160

Thus, when institutional or other factors inhibit robust judicial enforcement of a particular constitutional provision, it falls to the executive (and legislative) branch to enforce the provision more fully. Depending on the provision, this may entail the executive enforcing a constitutional constraint on its own actions, or it may involve the executive protecting itself against unconstitutional interference by the legislative branch. In either case, the general idea is well expressed in a I996 OLC opinion known colloquially as the Dellinger Memorandum:

The judiciary is limited, properly, in its ability to enforce the Constitution, both by Article III's requirements of jurisdiction and justiciability and by the obligation to defer to the political branches in cases of doubt or where Congress or the President has special constitutional responsibility. In such situations, the executive branch's regular obligation to ensure, to the full extent of its ability, that constitutional requirements are respected is heightened by the absence or reduced presence of the courts' ordinary guardianship of the Constitution's requirements. ${ }^{161}$

The same basic point may be extended (though somewhat more controversially) even to constitutional norms that the judiciary tends to enforce quite robustly. In every area of constitutional law, the Supreme Court's doctrine reflects its institutional limitations. ${ }^{162}$ A President not confined by those limitations and genuinely interested in implementing his best understanding of the Constitution might read any number of constitutional provisions more expansively. When that occurs, the President's oath arguably compels him to honor his more expansive under-

159. Sager, supra note 37 , at 1227.

160. Id.; see David A. Strauss, Presidential Interpretation of the Constitution, 15 Cardozo L. Rev. 113, 128-29 (1993) ("Sometimes the executive branch should interpret the Constitution to impose stricter limits on its power than the Supreme Court's decisions themselves suggest. That is because in certain categories of cases, constitutional law as developed by the Supreme Court reflects great deference to judgments made by the executive branch.").

161. The Constitutional Separation of Powers Between the President and Congress, 20 Op. Off. Legal Counsel 124, 180 (1996) [bereinafter Dellinger Memorandum] (footnote omitted). The Memorandum is named after then Assistant Attorney General Walter Dellinger, following the custom of referring to major OLC memoranda by the names of their authors. See H. Jefferson Powell, The President's Authority over Foreign Affairs: An Executive Branch Perspective, 67 Geo. Wash. L. Rev. 527, 530 n.14 (1999).

162. See Barron, supra note 2, at 69 (noting that Supreme Court doctrine is "everywhere comprised of tests and rules that compensate for or reflect the Court's own conception of the limitations of its decisional capacities"). 
standing. ${ }^{163}$ For this and related reasons, Akhil Amar and others have suggested that the Constitution builds in a preference for the most government-restrictive view of the law adopted by any of the three branches. ${ }^{164}$ On this view, even if the underlying constitutional provision is not especially underenforced by the courts, the Constitution is arguably designed to prefer whichever branch's implementation of the provision is most protective.

To be clear, I take no position here on how much more protective the executive branch should be of certain constitutional norms, judicially underenforced or otherwise. To engage that issue would be to argue about the appropriate substantive understanding of whatever constitutional norm is at issue. That is not my concern here. Instead, my aim over the last few paragraphs has been to establish that the executive branch (through the President) does have an independent responsibility to interpret and implement the Constitution, and that, depending on the constitutional norm involved, the executive's responsibility may entail enforcing the norm more robustly than the courts would.

From here, the constitutional enforcement theory's relevance to the executive branch should be clear. The fundamental aim of the avoidance canon as envisioned by the constitutional enforcement theory is to implement constitutional norms by resisting congressional forays into constitutionally sensitive areas. The avoidance canon, in other words, is understood as a statutory means of enforcing constitutional values. ${ }^{165}$ On that understanding, the executive branch's independent obligation to enforce the Constitution entails an obligation to use the avoidance canon.

To be sure, the mechanism of constitutional enforcement at work in avoidance is not the typical one. Rather than requiring the outright invalidation of unconstitutional statutes, the avoidance canon simply makes it more difficult for Congress to achieve certain results. It obliges

163. See Strauss, Choices, supra note 148, at 119-20 (“[I]f we imagine a President who has reached ... a negative conclusion ... about constitutionality, his pretending to adopt the opposite view in order to secure judicial review is, in itself, arguably a violation of his oath.").

164. See Akhil Reed Amar, Of Sovereignty and Federalism, 96 Yale L.J. 1425, 1504 (1987) ("[B] uilt into the general structure of the Constitution is a libertarian bias based on checks against constitutionally suspect laws and in favor of the broadest of the various constructions of the constitutional right given by the three branches."); see also Frank B. Cross, Institutions and Enforcement of the Bill of Rights, 85 Cornell L. Rev. 1529, 1535 (2000) (proposing allocation of interpretive authority among three branches that would create "a libertarian presumption that favors whichever institution is most protective of the liberty in question"). Although at first glance these proposals might seem to apply only to constitutional provisions directly securing individual rights, they are generalizable to questions of constitutional structure once we recall that the ultimate aim of both the separation of powers and federalism is to protect individual liberty. See generally The Federalist No. 51 (James Madison).

165. See Frickey, supra note 69, at 450 ("[T]he avoidance canon is not, strictly speaking, a rule of statutory interpretation-at least not as 'statutory interpretation' is ordinarily understood. ... [I]t is a rule of constitutional adjudication."). 
Congress to shoulder the institutional and political costs of being clear about its intent to enact constitutionally suspect legislation, and of then pushing that legislation through the gauntlet of bicameralism and presentment. ${ }^{166}$ The central claim of the enforcement theory in the courts is that this process counts as a form of constitutional enforcement. ${ }^{167} \mathrm{My}$ point here is that if one accepts that claim for the judiciary, the same should follow for the executive.

To see the constitutional enforcement theory at work in the executive branch, consider OLC's Dellinger Memorandum. ${ }^{168}$ The Memorandum was written during the Clinton Administration to provide a broad restatement of OLC views on various separation of powers issues, and is thus a significant OLC document in many respects. Of particular interest here is a section on statutory construction, which discussed whether statutes that do not expressly refer to the President should be construed to apply to him to the extent they would constrain his actions. ${ }^{169}$ According to the Memorandum, " $[t]$ he Supreme Court and this office have adhered to a plain statement rule: statutes that do not expressly apply to the President must be construed as not applying to the President, where applying the statute to the President would pose a significant question regarding the President's constitutional prerogatives." ${ }^{170}$ A clear statement form of avoidance is justified in that context, the Dellinger Memorandum reasoned, in order to "safeguard[] the usual constitutional balance of power."171 Moreover,

Given the central position that the separation of powers doctrine occupies in the Constitution's design, this rule also serves to "assure[ ] that the legislature has in fact faced, and intended to bring into issue, the critical matters" of the balance of power between the three branches of the federal government. ${ }^{172}$

The Dellinger Memorandum, in other words, implicitly embraced the constitutional enforcement theory of avoidance. More specifically, it adopted a clear statement version of that theory. The Memorandum's account of avoidance focused not on presumed legislative intent, but on requiring a plain statement in order to enforce the underlying constitutional norm (here, the "constitutional balance of power"). It stressed the

166. See Sunstein, Nondelegation Canons, supra note 97, at 339 (describing avoidance and other "nondelegation canons" as "protecting certain rights and interests not through a flat judicial ban on governmental action, but through a requirement that certain controversial or unusual actions will occur only with respect for the institutional safeguards introduced through the design of Congress").

167. As Professor Young explains, we view this process as constitutional "overenforcement" only to the extent that "we suffer from an overly narrow view of the ways in which constitutional provisions can limit governmental action." Young, supra note 44 , at 1585 .

168. See Dellinger Memorandum, supra note 161.

169. See id. at $178-80$.

170. Id. at 178.

171. Id. (internal quotation marks omitted)

172. Id. (quoting United States v. Bass, 404 U.S. 336, 349 (1971)). 
need for Congress to face the constitutional issues directly before its enactments will be construed to implicate them. Moreover, it is significant that the constitutional issues discussed in the Dellinger Memorandum concern separation of powers. Like federalism, the constitutional separation of powers is generally underenforced by the judiciary. ${ }^{173}$ Thus, it is an area where the constitutional enforcement theory applies with special force.

The Dellinger Memorandum thus stands as an exception to the more common executive practice, discussed above, ${ }^{174}$ of failing to explore the underlying values served by the avoidance canon. And by grounding the canon in the constitutional enforcement theory, the Memorandum chose a theory that would appear to work just as well in the executive branch as in the courts.

* $\quad * \quad *$

In sum, the judicial restraint and constitutional enforcement theories yield different answers to the question whether the executive branch should ever employ the modern avoidance canon. Under the judicial restraint theory, modern avoidance seems inapplicable in the executive branch. The constitutional enforcement theory, in contrast, is not institutionally specific. If it provides a persuasive account of avoidance in the courts, it should be persuasive in the executive branch as well. To be clear, my claim here is not that the executive branch must uniformly embrace the constitutional enforcement theory of avoidance. Rather, my aim is to stress that unless executive branch actors adopt some version of that theory, it will be difficult to justify avoidance in that branch. ${ }^{175}$

\section{Self-Protective Avoidance}

The Dellinger Memorandum's defense of avoidance in the separation of powers context reflects a broader trend in OLC's avoidance jurisprudence. Recent OLC opinions tend to employ avoidance most frequently-and most aggressively, using a clear statement requirement-in

173. See Young, supra note 44, at 1604 (stating that "it . . seems fair to characterize many aspects of the structural Constitution as "underenforced'"; noting, as separation of powers example, that "the Court [has] largely abandon[ed] attempts to limit Congress's delegation of power to the executive branch"); Martin H. Redish, The Constitution as Political Structure 6 (1995) (stating that Court has underenforced structural values). Jesse Choper has argued that the constitutional allocation of powers between the executive and legislative branches should be not just underenforced but entirely unenforced by the judiciary, on the ground that the political branches can adequately enforce those values themselves. See Jesse H. Choper, Judicial Review and the National Political Process 260-379 (1980). The courts, of course, have not embraced that position.

174. See supra text accompanying notes 124-126.

175. Embracing the constitutional enforcement theory of avoidance need not entail rejecting the judicial restraint theory. One might adopt both theories, in which case the former would support avoidance in the executive branch and both would support it in the courts. 
cases where the constitutional concern involves potential legislative encroachment upon what OLC considers to be the President's exclusive constitutional authority. ${ }^{176}$ In those circumstances, the avoidance canon functions as a kind of self-protection device. Confronted with a statute that threatens to invade what it views as the exclusive constitutional prerogatives and powers of the executive branch, OLC uses the avoidance canon to repel the invasion and preserve executive power. Whereas, for example, the executive's use of avoidance to construe a speech-restrictive statute would generally redound to the benefit of a private actor at the expense of the executive branch, here the executive branch itself is the beneficiary of its own constitutional avoidance.

1s this cause for concern? That is, if one adopts the constitutional enforcement theory and concludes that it is generally appropriate for the executive branch to employ the avoidance canon, should the answer change in circumstances where the executive uses avoidance in a selfprotective, even self-dealing, fashion? H. Jefferson Powell seems to say that it should. ${ }^{177} \mathrm{He}$ argues that it is categorically illegitimate for the executive to use avoidance to enhance executive power, likening it to "play[ing] with loaded dice." 178

I disagree. To see why, consider OLC's legal opinions addressing the executive's power to interrogate alleged enemy combatants held in the "war on terror." The most notorious of those opinions, known as the Bybee Memorandum, ${ }^{179}$ addressed the constraints imposed by a federal

176. See, e.g., The President's Constitutional Authority to Conduct Military Operations Against Terrorists and Nations Supporting Them, Op. Off. Legal Counsel (2001), at http://www.usdoj.gov/olc/warpowers925.htm (on file with the Columbia Law Review) ("[T] he Supreme Court ... has . . . emphasized that we should not construe legislative prerogatives to prevent the executive branch 'from accomplishing its constitutionally assigned functions." " (quoting Nixon v. Adm'r of Gen. Servs., 433 U.S. 425, 443 (1977))); President's Authority to Remove the Chairman of the Consumer Product Safety Commission, Op. Off. Legal Counsel (2001), at http://www.usdoj.gov/olc/cpsc chairmanremoval.htm (on file with the Columbia Law Review) ("[U]nless Congress signals a clear intention otherwise, a statute should be read to preserve the President's removal power, so as to avoid any potential constitutional problems." (providing cf. citation to Pub. Citizen v. U.S. Dep't of Justice, 491 U.S. 440, 466 (1989))).

177. See Powell, Executive, supra note 2, at 1315 (“My proposal . . . is that [executive branch lawyers] should never [use the avoidance canon] when the issue involves the commander-in-chief power or other questions about the separation of powers between Congress and the President."); id. at 1316 ("It is an error for the executive branch to employ the avoidance canon when the statute at issue implicates legislative-executive separation of powers issues generally, and emphatically so when the statute bears on, or seeks to structure, the exercise of the President's authority as commander in chief.").

178. Id. at 1317.

179. See Memorandum from Jay S. Bybee, Assistant Attorney Gen., Office of Legal Counsel, to Alberto R. Gonzales, Counsel to the President 34 (Aug. 1, 2002) (on file with the Columbia Law Review) [hereinafter Bybee Memorandum], subsequently withdrawn and replaced by Legal Standards Applicable Under 18 U.S.C. $\$ \S 2340-2340$ A, Op. Off. Legal Counsel (2004), at http://www.usdoj.gov/olc/18usc23402340a2.htm (on file with the Columbia Law Review). The Bybee Memorandum gets its name from its ostensible author, then Assistant Attorney General (and now federal judge) Jay S. Bybee. Although Bybee 
criminal statute implementing the international convention against torture. The statute makes it a crime for any person "outside the United States [to] commit[ ] or attempt[] to commit torture." ${ }^{180}$ The overall thrust of the Bybee Memorandum was to construe the statute narrowly so that it prohibits only a small set of particularly brutal actions. In addition, though, the Bybee Memorandum concluded that the statute would raise serious constitutional problems if it were construed to apply to any interrogation ordered by the President pursuant to his constitutional authority as Commander in Chief. Enter the avoidance canon:

In light of the President's complete authority over the conduct of war, without a clear statement otherwise, we will not read a criminal statute as infringing on the President's ultimate authority in these areas. We have long recognized, and the Supreme Court has established a canon of statutory construction that statutes are to be construed in a manner that avoids constitutional difficulties so long as a reasonable alternative construction is available. This canon of construction applies especially where an act of Congress could be read to encroach upon powers constitutionally committed to a coordinate branch of government.

ln the area of foreign affairs, and war powers in particular, the avoidance canon has special force. We do not lightly assume that Congress has acted to interfere with the President's constitutionally superior position as Chief Executive and Commander in Chief in the area of military operations.

... [T] he President's power to detain and interrogate enemy combatants arises out of his constitutional authority as Commander in Chief. A construction of Section 2340A that applied the provision to regulate the President's authority as Commander in Chief to determine the interrogation and treatment of enemy combatants would raise serious constitutional questions. . . Accordingly, we would construe Section 2340A to avoid this constitutional difficulty, and conclude that it does not apply to the President's detention and interrogation of enemy combatants pursuant to his Commander-in-Chief authority. ${ }^{181}$

signed the memorandum in his capacity as head of OLC, many believe that then Deputy Assistant Attorney General John Yoo was heavily involved in its writing. See, e.g., David Cole, What Bush Wants to Hear, N.Y. Rev. Books, Nov. 17, 2005, at 8, 8 (calling Bybee Memorandum “Yoo's most famous piece of advice"). As just noted, the Bybee Memorandum, issued on August 1, 2002, was withdrawn and replaced by a more modest memorandum on December 30, 2004. I do not discuss the Bybee Memorandum here for purposes of establishing current OLC views on the law of torture, but simply as an illustration of the ways OLC has employed the avoidance canon.

180. 18 U.S.C. $\$ 2340$ A (2000).

181. Bybee Memorandum, supra note 179 , at $34-35$ (citations omitted). The Memorandum went on to conclude, in the alternative, that if Section 2340A must be read to apply to interrogations ordered by the President, it would be unconstitutional. See id. at 36-39. That conclusion is just as problematic as the constitutional analysis driving the 
In the two years since it was leaked to the public, the Bybee Memorandum has been withered by criticism for the poor quality of its legal analysis. ${ }^{182}$ Focusing just on the Memorandum's use of avoidance, there are a number of problems. First, although the avoidance canon is limited to cases of statutory ambiguity, the torture statute does not appear ambiguous on the point in question. By its terms it contains no suggestion that presidentially-ordered torture is somehow exempt from its prohibitions. ${ }^{183}$ Thus, there is no ambiguity for the avoidance canon to engage. Second, the constitutional vision driving the Memorandum's analysis is seriously flawed. Indeed, the Memorandum failed even to cite, much less discuss, the most significant separation of powers precedent of the postWorld War Il era-Justice Jackson's concurring opinion in The Steel

Memorandum's avoidance analysis. For present purposes, however, I am interested only in that part of the Memorandum that invoked and relied on modern avoidance.

182. See, e.g., Confirmation Hearing on the Nomination of Alberto R. Gonzales to Be Attorney General of the United States Before the S. Comm. on the Judiciary, 109th Cong. 158 (2005) (statement of Harold Hongju Koh, Dean, Yale Law School) ("[1]n my professional opinion ... the [Bybee] Memorandum is perhaps the most clearly erroneous legal opinion I have ever read."); W. Bradley Wendel, Legal Ethics and the Separation of Law and Morals, 91 Cornell L. Rev. 67, 68 (2005) ("This is not legal analysis of which anyone could be proud. The overwhelming response by experts in criminal, international, constitutional, and military law was that the legal analysis in the [Bybee Memorandum] was so faulty that the lawyers' advice was incompetent."); Eric Lichtblau, Justice Nominee Is Questioned on Department Torture Policy, N.Y. Times, July 27, 2005, at A18 (reporting that Timothy Flanigan, who had been Deputy White House Counsel when Bybee Memorandum was issued, stated in hearings regarding his (later withdrawn) nomination to be Deputy Attorney General that he found Memorandum "sort of sophomoric"); Adam Liptak, Legal Scholars Criticize Memos on Torture, N.Y. Times, June 25, 2004, at A14 (quoting, inter alios, Cass Sunstein describing legal analysis as "very low level . . very weak, embarrassingly weak, just short of reckless" (internal quotation marks omitted)).

183. 18 U.S.C. $\$ 2340 \mathrm{~A}$ reads in full:

(a) Offense.-Whoever outside the United States commits or attempts to commit torture shall be fined under this title or imprisoned not more than 20 years, or both, and if death results to any person from conduct prohibited by this subsection, shall be punished by death or imprisoned for any term of years or for life.

(b) Jurisdiction.-There is jurisdiction over the activity prohibited in subsection

(a) if-

(1) the alleged offender is a national of the United States; or

(2) the alleged offender is present in the United States, irrespective of the nationality of the victim or alleged offender.

All agree that the statute's reference to "whoever" includes U.S. government officials. Tbat point is reinforced by the statute's definition of torture as "an act committed by a person acting under the color of law specifically intended to inflict severe physical or mental pain or suffering (other than pain or suffering incidentaI to lawful sanctions) upon another person within his custody or physical control." 1d. $\$ 2340(1)$ (empbasis added). Moreover, the rule requiring a clear statement before a statute will be read to apply to the President (discussed above in connection with the Dellinger Memorandum, see supra text accompanying notes 168-172) does not apply here, since the question is not whether the President himself may be prosecuted for violating the statute, but whether any government official may be prosecuted under the statute for actions ordered or authorized by the President. 
Seizure Case. ${ }^{184}$ These two flaws in the Bybee Memorandum stand as prominent examples of the ways in which the avoidance canon can be abusively applied, a point to which I will return in Part 1I1.D.

More pertinently for present purposes, and wholly apart from the application-oriented problems just cited, some might follow Professor Powell's argument and fault the Bybee Memorandum on grounds of selfdealing. ${ }^{185}$ That is, even if the torture statute were ambiguous, and even if the otherwise preferred reading of the statute did raise serious constitutional concerns, some might nevertheless criticize the Bybee Memorandum's use of avoidance on the ground that the executive branch was the principal beneficiary of the Memorandum's analysis.

I think this criticism is misguided. ${ }^{186}$ To be sure, executive use of the avoidance canon in the separation of powers area can sometimes carry an air of self-dealing. But that alone does not make it illegitimate. lndeed, in some respects the checks and balances in our constitutional system are a function of departmental self-dealing, or at least selfprotection. "Ambition," James Madison explained, "must be made to counteract ambition." 187 To that end, "the great security against a gradual concentration of the several powers in the same department consists in giving to those who administer each department the necessary constitutional means and personal motives to resist encroachments of the others." 188 The avoidance canon provides just such a means for an executive branch motivated to protect itself from legislative intrusions.

184. See Youngstown Sheet \& Tube Co. v. Sawyer, 343 U.S. 579, 634 (1952) (Jackson, J., concurring). For statements of the influence of Justice Jackson's analytical framework, see, e.g., Curtis A. Bradley \& Jack L. Goldsmith, Congressional Authorization and the War on Terrorism, 118 Harv. L. Rev. 2047, 2050 (2005) (describing framework as "widely accepted"); Neal K. Katyal \& Laurence H. Tribe, Waging War, Deciding Guilt: Trying the Military Tribunals, 111 Yale L.J. 1259, 1274 (2002) (calling it "canonical").

185. See supra text accompanying notes $177-178$.

186. To be clear, $1 \mathrm{am}$ not saying that the Byhee Memorandum itself provided an adequate theoretical account of why executive branch actors should apply the avoidance canon. To the extent the passage quoted in the text embraces any theory of avoidance at all, it seems to be a fairly careless mélange of both the judicial restraint and constitutional enforcement theories. 1 am not suggesting that this was sufficient in terms of theoretical grounding. Rather, assuming one has already considered and accepted the constitutional enforcement theory of avoidance, I am using the Bybee Memorandum as a vehicle for arguing that the self-protective nature of a particular instance of avoidance in the executive branch does not, by itself, render it illegitimate.

187. The Federalist No. 51, at 322 (James Madison) (Clinton Rossiter ed., 1961).

188. Id. at 321-22; see also Clinton v. City of New York, 524 U.S. 417, 452 (1998) (Kennedy, J., concurring) (stating that purpose of separation of powers is to "ensure the ability of each branch to be vigorous in asserting its proper authority"); Louis Fisher, Constitutional Conflicts Between Congress and the President 10 (4th ed. 1997) ("Without the power to resist encroachments by another branch, a department might find its powers drained to the point of extinction."); Mark Tushnet, Evaluating Congressional Constitutional Interpretation: Some Criteria and Two Informal Case Studies, in Congress and the Constitution, supra note 2, at 269, 276 ("The Constitution gave members of Congress and the president political interests that would be served by preserving the power of their respective institutions, setting the institutions and their memhers at political odds 
Moreover, the courts themselves sometimes employ the avoidance canon in self-protective ways. ${ }^{189} I N S v . S t$. Cyr is a prime example. ${ }^{190}$ In that case, the Supreme Court reviewed a statute providing that, " [n] otwithstanding any other provision of law, no court shall have jurisdiction to review any final order of removal against an alien who is removable by reason of having committed' [certain] criminal offense [s]."191 The question was whether, despite the provision, the federal district courts retained their statutorily conferred habeas corpus jurisdiction to review certain challenges to the affected aliens' removal orders. ${ }^{192} \ln$ addressing that question, the Court invoked a number of interpretive canons, including "the longstanding rule requiring a clear statement of congressional intent to repeal habeas jurisdiction" 193 and an aggressive, clear statement version of avoidance. ${ }^{194}$ Applying those rules, the Court concluded that Congress had not divested the courts of the jurisdiction in question. ${ }^{195}$ This was judicial self-protection: Congress had passed legislation arguably stripping the courts of an important and historic jurisdiction and remedy, and the Court used the avoidance canon to repel Congress's efforts. ${ }^{196}$ lf it is permissible for courts to employ avoidance

over the distribution of power within the national government."). But see Daryl J. Levinson, Empire-Building Government in Constitutional Law, 118 Harv. L. Rev. 915, 920 (2005) (arguing that government officials more often act on basis of personal and political incentives that do not entail defending institutional powers and prerogatives of their branch). Professor Levinson does not completely reject the Madisonian view of interbranch competition, but instead argues that it does not describe all parts of the federal government equally well. Referring specifically to modern executive and legislative practices, he argues that "the picture that emerges [is] of somewhat imperial modern presidents and stubbornly passive Congresses." 1d. at 957. It remains to be seen whether Congress will shed that passivity in current controversies such as the presidentially authorized, but seemingly statutorily prohibited, surveillance of domestic communications. See infra Part IV.B.3 for further discussion of that issue.

I89. As Mark Tushnet has pointed out, the judiciary is certainly not immune from the self-aggrandizing interests more frequently associated with the other two branches. See Tushnet, Taking the Constitution Away, supra note 2, at 26 ("If members of Congress have an incentive to maximize the sphere of their power and responsibilities, so do Supreme Court justices with respect to their sphere.").

190. 533 U.S. 289 (2001).

191. Id. at 311 (quoting 8 U.S.C. $\$ 1252(a)(2)(C)$ (2000) (amended 2005)).

192. See id. at 298.

193. Id.

194. Id. at 299-300. In addition to the habeas and avoidance canons, the Court invoked the rule that "when a particular interpretation of a statute invokes the outer limits of Congress' power, we expect a clear indication that Congress intended that result." $1 \mathrm{~d}$. at 299. The Court seems to have treated that rule as a freestanding clear statement rule overlapping substantially with the avoidance canon.

195. See id. at 314.

196. Self-protection is a feature of other judicially developed canons as well. For example, the Court has long embraced the principle that, "[a]bsent the clearest command to the contrary from Congress," courts retain their traditional authority to issue equitable relief. Califano v. Yamasaki, 442 U.S. 682, 705 (1979). Relatedly, the Court has instructed that statutes in derogation of the common law should be construed narrowly. E.g., Robert 
for such purposes, it seems appropriate to grant the executive branch that option as well. ${ }^{197}$

One might object here that the presidential veto power makes the executive's self-protective use of avoidance uniquely powerful. Suppose Congress passes legislation aimed at regulating certain presidential or other executive branch functions. If a broad construction of the statute would raise serious constitutional questions under Article II, and if a narrower, constitutionally unproblematic construction is reasonably possible, then an executive actor called upon to construe the statute is likely to invoke avoidance and opt for the narrower reading. If Congress insists on the broader meaning, it can respond by legislating more clearly. At that point, however, the President may well veto the legislation. In that respect, executive use of avoidance to protect executive power is potentially more powerful than in other circumstances, because Congress may need a veto-proof supermajority to overcome the avoidance-driven construction. 198

I agree that the executive's self-protective use of avoidance is especially forceful when backed by the prospect of the veto. But that does not mean we should reject it. The constitutional structure is not perfectly symmetrical. Each branch wields certain powers not held by the other two, and those powers give each branch certain advantages. Thus, because the President has the power to sign or veto legislation, his use of an interpretive rule like the avoidance canon can carry special force. Yet the judiciary has certain advantages too. In particular, to paraphrase Justice Jackson's wry turn of phrase, the Supreme Court's institutional position renders its legal interpretations infallible by virtue of their finality. ${ }^{199}$ Thus when the Court uses avoidance to protect its own jurisdiction in a case like St. Cyr, its construction of the statute is final. And if Congress

C. Herd \& Co. v. Krawill Mach. Corp., 359 U.S. 297, 304-05 (1959). Justice Scalia has called that rule "a sheer judicial power-grab." Scalia, supra note 9, at 29.

197. 1 do not mean to say that there are no important differences between cases like St. Cyr and executive branch opinions like the Bybee Memorandum. There surely are. Among other things, the judiciary's protection of its own jurisdiction in St. Cyr also had an immediate individual rights payoff: The Court preserved certain aliens' right to challenge their removal orders in court. The Bybee Memorandum, in contrast, clearly did not enhance the rights of enemy combatant detainees. From an individual rights perspective, then, St. Cyr is much more attractive than the Bybee Memorandum. But even accepting that point, my argument here is that along with whatever benefits St. Cyr had for individual rights, it also involved the judiciary using the avoidance canon to protect its own power. And that feature of the case may have provided an incentive for the Court to decide the case as it did. The self-dealing objection to avoidance in the executive branch is that the incentive to protect executive power somehow delegitimizes the use of avoidance in such cases. But if the self-dealing incentives present in St. Cyr did not delegitimize the judiciary's use of avoidance in that case, neither should the existence of comparable incentives in the executive branch categorically delegitimize avoidance in that context.

198. See U.S. Const. art. $1, \S 7$ (requiring two-thirds majority in each House to override presidential veto).

199. See Brown v. Allen, 344 U.S. 443, 540 (1953) (Jackson, J., concurring) ("We are not final because we are infallible, but we are infallible only because we are final."). 
responds by legislating more clearly, the Court has the option of rendering a final judgment striking down the statute as unconstitutional. ${ }^{200}$

In sum, if it is acceptable for the judiciary to employ avoidance in a self-protective fashion, nothing in the constitutional enforcement theory compels a contrary conclusion for the executive branch.

\section{The Risk of Abuse}

To conclude that the constitutional enforcement theory provides a generally workable justification for avoidance in the executive branch is not, of course, to say that all executive applications of avoidance are unproblematic. There is a risk that executive actors will abuse the avoidance canon by employing it in circumstances where, by its own terms, it does not apply. Specifically, they might impose avoidance on a statute that is not sufficiently ambiguous to trigger the canon, ${ }^{201}$ and/or they might rely on a marginal or even fanciful constitutional "concern" to drive the analysis. ${ }^{202}$

200. Moreover, the theoretical influence of the President's veto power may outstrip its practical force. Whereas the judiciary is relatively insulated from the political process and thus can exercise the power of judicial review without much fear of political reprisal, it may be politically costly for the President to use the veto. Thus, when forced to face the veto question directly, a President who would happily construe an anbiguous statute narrowly to avoid Article II concerns may be less enthusiastic about assuming the political costs of vetoing legislation raising those same concerns. Avoidance and the veto meet, in a sense, in the area of presidential signing statements, which I address in Part IV.B.2, infra.

201. See Clark v. Martinez, 543 U.S. 371, 385 (2005) ("The canon of constitutional avoidance comes into play only when, after the application of ordinary textual analysis, the statute is found to be susceptible of more than one construction; and the canon functions as a means of choosing between them."); United States v. Oakland Cannabis Buyers' Coop., 532 U.S. 483, 494 (2001) (" $[T]$ he canon of constitutional avoidance has no application in the absence of statutory ambiguity.”). 1 discuss cases where the executive employed avoidance in the absence of genuine statutory ambiguity in Parts IV.B.2 and IV.B.3, infra.

202. For an example of a case where the Supreme Court refused to employ avoidance on the ground that the asserted constitutional concerns were too insubstantial, see Rust $\mathbf{v}$. Sullivan, 500 U.S. 173, 191 (1991) ("Applying the [avoidance] canon ... as best we can, we hold that the regulations promulgated by the Secretary do not raise the sort of 'grave and doubtful constitutional questions,' . . . that would lead us to assume Congress did not intend to authorize their issuance." (quoting United States ex rel. Attorney Gen. v. Del. \& Hudson Co., 213 U.S. 366, 408 (1909))). Rust involved a challenge to a federal statute providing that certain family-planning funds could not be used by programs that provided abortion counseling, and the Court's decision upholding the provision was highly controversial. In her dissenting opinion, Justice O'Connor reasoned that prohibiting abortion counseling by fund recipients would raise serious constitutional questions, and thus that the Court should have employed avoidance to construe the statute more narrowly. See id. at 223-25 (O'Connor, J., dissenting). Justices Blackmun, Marshall, and Stevens went further, concluding that the provision as construed by the majority was unconstitutional. See id. at 204 (Blackmun, J., dissenting). In citing the Rust majority here, 1 do not mean to convey agreement with the Court's conclusion that the constitutional concerns attending its interpretation of the statute were too weak to trigger avoidance. But assuming arguendo that the Court was right on that score, Rust confirms the formal point that the avoidance canon is not triggered unless the constitutional concern is relatively serious. 
For obvious reasons, the risk of these abuses is especially acute in self-protective circumstances. Faced with legislation purporting to impose limits on the executive branch, executive officials will have an incentive to resist those limits however they can. The avoidance canon is particularly attractive for those purposes, since it enables the executive branch to evade the congressional limitations in question without having to commit to a (perhaps politically costly) position that the limits are actually unconstitutional. In order to repel congressional encroachments upon executive power in a "quieter" fashion, the executive may thus be tempted to abuse the avoidance canon by fabricating statutory ambiguity and exaggerating constitutional concerns. ${ }^{203}$ As noted above, the Bybee Memorandum stands as a particularly salient example of both of these abuses. ${ }^{204}$

On the other hand, the executive branch does not hold a monopoly on abusing the avoidance canon. As noted in Part II.B, critics of avoidance in the courts often charge that it provides judges with a license to contort statutes to the point of unrecognizability. ${ }^{205}$ Like executive officials, judges might perform such contortions in order to make the statute fit their own policy preferences or to protect their own institutional power. Yet, provided one has adopted a theoretically satisfying general account of avoidance in the courts, the risk of abuse need not completely undermine the canon itself. Instead, the risk of abuse means we should carefully examine particular applications of the avoidance canon to ensure the courts are acting reasonably and in good faith.

The same should hold true for avoidance in the executive branch. If the risk of "avoidance abuse" does not undermine the canon's general theoretical legitimacy in the courts, then neither should it doom avoidance in the executive branch. Instead, we should focus on whether individual applications of avoidance in the executive branch-particularly those that serve the executive's own institutional interests-are consistent with the canon's basic predicates of genuine statutory ambignity and legitimate constitutional concern. If those predicates are not met in a particular case, we likely will have located a circumstance where politics has

203. This appears to be one of Professor Powell's main concerns, though for him it produces a categorical opposition to avoidance in the executive branch. As he puts it,

The result of the avoidance canon is a United States Code full of provisions that look like rules of law, which members of Congress may well believe to be rules of law, but which the executive branch treats as suggestions of congressional preference to be followed or ignored at leisure. In contrast, when the executive admits that it intends to disobey an act of Congress on constitutional grounds, it is unlikely to do so on the basis of specious or flimsy reasoning, and Congress and the public at large can more easily grasp the scope and plausibility of the President's claims of authority.

Powell, Executive, supra note 2, at 1317-18.

204. See supra text accompanying notes 179-186.

205. See supra text accompanying notes $68-70$. 
trumped law-not in the selection of avoidance as a generally appropriate rule, but in its application in that case.

Finally, and importantly, concern for abuse should extend as well to cases where the executive branch fails to use avoidance. If we view avoidance as a means of constitutional enforcement, then the President's duty to enforce the Constitution includes the obligation to employ avoidance whenever it is triggered. Avoidance is not then an optional technique, to be employed at the executive's discretion; it applies across the board, regardless of the constitutional provision at issue. The risk is that in situations where a broad reading of a power-granting statute would raise serious questions under some individual rights or other governmentconstraining provision of the Constitution, executive actors might simply ignore those concerns and adopt the broad construction. That is, the risk is that the executive branch will not follow avoidance in situations where doing so would limit its own statutory authority.

Thus, just as we must examine the executive's self-protective deployments of avoidance with special scrutiny, we must look for the dog that didn't bark ${ }^{206}$ _ cases where the executive should have read a statute narrowly to avoid serious individual-rights or comparable concerns, but where it neglected avoidance altogether and instead construed the statute in broad, government-friendly terms. Put simply, non-use of avoidance can be just as worrisome as overuse.

\section{E. The Need for Congressional Notification}

One final point bears emphasizing in this section. Although the constitutional enforcement theory provides a sound theoretical basis for employing the avoidance canon in the executive branch, it comes with an important condition: Congress should be notified when the executive branch uses the canon.

As discussed above, the enforcement theory sees avoidance as a means of resisting legislative incursions on constitutional values by requiring Congress to speak clearly before its enactments will be read to implicate those values. ${ }^{207}$ Implicit in-indeed, central to-this view is the presumption that Congress knows (or at least could know, upon investigation ${ }^{208}$ ) when a law has been narrowed by way of avoidance, so

206. The phrase refers to a passage from a Sherlock Holmes story involving the nighttime disappearance of a racehorse whose stall had been protected by a guard dog. 1 Arthur Conan Doyle, Silver Blaze, in The Complete Sherlock Holmes 335 (Doubleday \& Co. 1930) (1894). While talking with Inspector Gregory, Holmes refers to "the curious incident of the dog in the night-time." Id. at 347. Gregory notes that the dog had done nothing. Id. "That," Holmes replies, "was the curious incident." Id.

207. See supra text accompanying notes 94-99, 142-144.

208. I do not mean to suggest that every member of Congress personally scrutinizes every judicial opinion interpreting a federal statute, taking note of every invocation of the avoidance canon. As in so many other areas of the law, the notice here is probably more often constructive than real. But it remains important because the mechanisin of 
that it can contemplate enacting new legislation that more clearly expresses the meaning foreclosed by avoidance. Such congressional notice invariably accompanies the judicial use of avoidance, since courts announce their interpretations in published opinions. Thus, members of Congress are able to know when a court has used avoidance to narrow a statute.

Executive branch statutory interpretation, in contrast, is not always so visible. Part of the variation here is a matter of formality: Some executive branch statutory interpretations are memorialized in formal documents like OLC opinions, but others are far more informal. ${ }^{209}$ Yet even among the more formalized interpretations, the executive branch does not always publicize its work. The Bybee Memorandum, for example, only became known to the public when it was leaked to the press almost two years after it was issued. ${ }^{210}$ Until the leak, members of Congress were presumably unaware that this extremely significant executive branch opinion had relied on the avoidance canon to "conclude that [the statutory prohibition on torture] does not apply to the President's detention and interrogation of enemy combatants pursuant to his Commander-inChief authority."211 Such secret uses of avoidance are at odds with the operating premises of the constitutional enforcement theory. If Congress does not even know that the executive branch has used avoidance to construe a statute narrowly, the canon cannot be defended as a means of protecting constitutional norms by effectively remanding Congress to the legislative process. Congress, after all, would not even know of the remand.

To be sure, there may be legitimate national security or other compelling reasons not to publicly disclose the full contents of a document like the Bybee Memorandum, at least when it is first produced. But if the executive branch chooses to employ the avoidance canon when it interprets a statute, it assumes a responsibility to inform Congress. Surely it is possible to discharge that responsibility without compromising national security. In the case of the Bybee Memorandum, the Administration could have told Congress that it had decided to construe the torture statute narrowly on grounds of avoidance, even if it would not have been appropriate to disclose the full contents of the Bybee Memorandum itself. ${ }^{212}$ In other circumstances, such as the National Security Agency's

constructive notice-public disclosure of the avoidance canon's use-makes congressional oversight possible for those inclined to exercise it.

209. See Mashaw, Paradox of Deference, supra note 2, at 525 (noting variety in "occasions," "forms," and "processes" of executive branch statutory interpretation); see also supra text accompanying notes 4-5.

210. See Dana Priest \& R. Jeffrey Smith, Memo Offered Justification for Use of Torture: Justice Dept. Gave Advice in 2002, Wash. Post, June 8, 2004, at Al (describing Bybee Memorandum as "newly obtained memo").

211. Bybee Memorandum, supra note 179, at 34-35.

212. To be clear, I am not necessarily saying that full publication of the Bybee Memorandum would have been inappropriate. But even if it would have been 
electronic surveillance program discussed below, ${ }^{213}$ it might be appropriate for the executive to provide classified briefings to just a few congressional leaders. But those briefings should not merely report the existence of a particular executive branch program; they should also specify the legal authority the executive branch is relying on for its program. In particular, to the extent the executive's claimed authority rests on certain statutory interpretations, and to the extent those interpretations depend on the avoidance canon, Congress (or at least its leaders) should be told.

In short, although the constitutional enforcement theory provides a generally sound basis for executive use of the avoidance canon, it also assumes that the process of statutory interpretation happens in public view. Even granting that statutory interpretation in the executive branch cannot always be as public as it is in the courts, executive actors using the avoidance canon should nevertheless be understood to assume a responsibility of congressional notification. ${ }^{214}$

* $\quad * \quad *$

1 have endeavored to show in this section that whether the avoidance canon is appropriate in the executive branch turns, first, on whether one adopts the judicial restraint or constitutional enforcement theory. I have not sought to argue that one theory or the other necessarily provides a better account of the canon. Rather, my principal aim has been to highlight the nature of the tradeoff between the two. In short, my claim is that if one thinks the conventional judicial restraint theory provides the best account of avoidance, then there is little basis for its use in the executive branch. But if one embraces the constitutional enforcement theory, then it is appropriate for executive actors to employ avoidance in all cases where it applies, and to notify Congress when they do.

\section{The Avoidance Canon in the Executive Branch: EXAMINING INTERPRETIVE CONTEXT}

In Part III, I showed that unless one adopts the constitutional enforcement theory of avoidance, it will be exceedingly difficult to justify the avoidance canon in the executive branch. But even if one does adopt the constitutional enforcement theory, it might not be appropriate for the executive branch to use avoidance in every situation where a court

inappropriate, there were other ways to inform Congress of the statutory interpretation in question.

213. See infra Part IV.B.3.

214. Under 28 U.S.C. $\$ 530 \mathrm{D}$, the Attorney General is required to notify Congress whenever the Department of Justice decides not to enforce a federal statute on grounds of unconstitutionality. 28 U.S.C. $\$ 530 D$ (a) (1)(A) (i) (Supp. 2003). One way for Congress to implement the notification obligation I have described would be to amend $\$ 530 \mathrm{D}$ to require notification whenever the Department of Justice or other executive component decides to implement a statute in conformity with a construction adopted in order to avoid a serious constitutional concern. 
would do so. That is because the precise context of a particular executive interpretation might affect the avoidance canon's applicability. Thus, assuming one regards the enforcement theory as providing an adequate general account of avoidance in the executive branch, the question then becomes whether, and when, variations in interpretive context might affect the canon's applicability.

\section{A. The Information Richness of Executive Statutory Interpretation}

Like other substantive interpretive rules, the avoidance canon is a tool for managing statutory ambiguity. The canon does not eliminate ambiguity by resolving uncertainty about statutory meaning; it manages ambiguity by assigning a consequence to the uncertainty. Whether it is appropriate to assigu that consequence may depend on the interpreter's capacity to resolve the statutory ambiguity by other, more direct means. If those means provide a resolution, then it would be unnecessary, even inappropriate, for the interpreter to invoke avoidance. ${ }^{215}$

Statutory interpretation in the executive branch often takes place in a much more information-rich environment than does statutory interpretation in the courts. This is particularly true of statutory interpretation within administrative agencies. Because they have "programmatic responsibility for implementing statutory regimes," 216 and because they interact frequently with Congress in the course of discharging that responsibility, ${ }^{217}$ agencies often have a very nuanced sense of congressional aims and statutory purpose. Indeed, as Edward Rubin has explained, while we may sensibly regard courts and Congress as two strangers linked only by a common language:

[A] Iegislature and the administrative agencies within the same jurisdiction are linked by an incredibly dense network of relationships and shared activities. A much better analogy than two English-speaking strangers would be two members of a single family. The legislature and the agencies spend their entire lives supporting, attacking, cajoling, commanding, resisting, annoying, deceiving, upsetting, consoling, protecting, correcting, and wounding each other. Like family members, they develop a shared and specialized set of linguistic understandings based on this continuous, intense relationship. To restrict them to the discourse of strangers would distort and constrain modern governmental processes. ${ }^{218}$

215. See supra note 201 (identifying cases establishing that avoidance applies only in cases of statutory ambiguity).

216. Strauss, Agency Interpretation, supra note 2, at 321.

217. See id. at 331-35; William N. Eskridge, Jr. \& Philip P. Frickey, The Supreme Court, 1993 Term-Foreword: Law as Equilibrium, 108 Harv. L. Rev. 26, 71-72 (1994) ("Because of their place in governance, agencies are both knowledgeable about and responsive to presidential and congressional preferences.").

218. Edward L. Rubin, Modern Statutes, Loose Canons, and the Limits of Practical Reason: A Response to Farber and Ross, 45 Vand. L. Rev. 579, 586 (1992). 
As a result of this more intimate institutional relationship, agencies may often be in a position to draw on sources of statutory meaning not readily accessible to courts. ${ }^{219}$ By appearing before and corresponding with the congressional committees that drafted a statute, for example, agency officials may be both more familiar with the considerations that went into the statute's drafting and better able to place certain parts of the legislative record in the proper context. ${ }^{220}$ This informational superiority may, in turn, bring clarity to otherwise ambiguous statutory language. When that occurs, there is no need for the avoidance canon. That is, although the plain text of a statute might appear ambiguous, and although one possible reading of the statute would raise constitutional doubts sufficient to trigger the avoidance canon, the agency may be in a position to resolve the statutory ambiguity without recourse to the avoidance canon. On one hand, extratextual sources of meaning may lead the agency to conclude that the doubts-raising reading is the only correct one, in which case statutory clarity will trump the avoidance canon. On the other hand, extratextual sources may compel the conclusion that the doubts-avoiding reading is the only correct one, in which case the avoidance canon is unnecessary because the constitutional doubts are never engaged. In short, an agency's access to, and familiarity with, extratextual sources of statutory meaning may often leave little or no room for constitutional avoidance.

This point needs to be qualified in two ways, however. First, it assumes that executive branch statutory interpretation takes account of statutory purpose and legislative intent, and relies in part on legislative history and other extratextual sources when doing so. There is, of course, a lively and ongoing academic debate over whether it is legitimate for courts to rely on extratextual sources when construing statutes. ${ }^{221}$ There are a variety of arguments against this practice, some of which would seem to

219. See Mashaw, Paradox of Deference, supra note 2, at 511 ("[A]gencies have a direct relationship with Congress that gives them insights into legislative purposes and meaning that are likely to be much more sure-footed than those available to courts in episodic litigation." (construing Strauss, Agency Interpretation, supra note 2)).

220. As Professor Strauss has noted:

An agency's participation in the debates [leading to a statute's enactment] . . . may well permit it to say, as a court never could, whether the reference to three district court opinions in a report fairly reflects the resolution of argument about what will be in the language of a bill, or an adventitious midnight insertion.

Strauss, Agency Interpretation, supra note 2, at 347 (referring to issue that arose in Blanchard v. Bergeron, 489 U.S. 87 (1989), and to Justice Scalia's discussion, id. at 98, of process by which certain references may have been included in committee report).

221. The literature is too vast to cite here, but an illustrative exchange on the issue is Jonathan R. Siegel, The Use of Legislative History in a System of Separated Powers, 53 Vand. L. Rev. 1457 (2000), John F. Manning, Putting Legislative History to a Vote: A Response to Professor Siegel, 53 Vand. L. Rev. 1529 (2000) [hereinafter Manning, Legislative History], and Jonathan R. Siegel, Timing and Delegation: A Reply, 53 Vand. L. Rev. 1543 (2000). 
apply not only to courts but to executive actors as well. ${ }^{222}$ To proponents of those views, this part of my argument is unlikely to be persuasive. ${ }^{223}$ But objections to the judicial use of legislative history do not necessarily apply to the executive branch. Justice Scalia, for example, asserts that "it ... facilitate[s] rather than deter[s] decisions that are based upon the courts' policy preferences, rather than neutral principles of law."224 That argument focuses especially on the impropriety of an unelected judiciary displacing legislative choices with policy preferences of its own, and has much less purchase in the more democratically accountable executive branch.

Moreover, the affirmative case for using legislative history may be stronger in the executive branch than it is in the courts. As just discussed, agencies typically have a much more intimate, ongoing relationship with Congress and the legislative process. ${ }^{225}$ Unlike courts, they do not simply read the legislative history after it has been generated and compiled; they participate in the legislative process itself. This often yields a more detailed, nuanced, and unmediated understanding of statutory purpose. As

222. John Manning, for example, has argued that courts should adopt a textualist approach to statutory in terpretation in order to protect against what he calls legislative selfdelegation. See John F. Manning, Textualism as a Nondelegation Doctrine, 97 Colum. L. Rev. 673, 706-25 (1997) [hereinafter Manning, Nondelegation Doctrine]. The idea here is that "[ilf the judiciary accepts certain types of legislative history (committee reports and sponsors' statements) as 'authoritative' evidence of legislative intent in cases of ambiguity, then the particular legislators who write that history (the committees and sponsors) effectively settle statutory meaning for Congress as a whole." Manning, Legislative History, supra note 221 , at 1529 . When Congress passes a facially ambiguous statute against the backdrop of this judicial interpretive practice, "it thereby implicitly delegates its lawelaboration authority to legislative agents, who effectively fashion the details of meaning outside the enacted text." 1d. at 1529-30. To the extent this argument provides a persuasive case against the use of legislative history in judicial statutory interpretation, it would appear just as persuasive in the executive branch. On the other hand, even Professor Manning does not rule out the judicial use of legislative history in certain circumstances. See Manning, Nondelegation Doctrine, supra, at 731-32 (suggesting that it may be permissible for courts to consult "legislative history that does not just declare congressional intent, but that supplies an objective, unmanufactured history of a statute's context"). Presumably, he would also condone the executive use of such legislative history.

223. I do not want to overstate my concession here. Even if certain opponents to the use of legislative history reject the main argument in this section, the arguments set forth in Parts I-III, as well as Part IV.B.1, should still have purchase.

224. Scalia, supra note 9 , at 35 . Justice Kennedy has expressed a similar, though less categorical, concern:

Where it is clear that the unambiguous language of a statute embraces certain conduct, and it would not be patently absurd to apply the statute to such conduct, it does not foster a democratic exegesis for this Court to rummage through unauthoritative materials to consult the spirit of the legislation in order to discover an alternative interpretation of the statute with which the Court is more comfortable. ... The problem with spirits is that they tend to reflect less the views of the world whence they come than the views of those who seek their advice.

Pub. Citizen v. U.S. Dep't of Justice, 491 U.S. 440, 473 (1989) (Kennedy, J., concurring in the judgment).

225. See supra text accompanying notes 216-220. 
Peter Strauss and others have argued, it would be senseless for an agency to disregard all that additional information when called upon to interpret a statute. ${ }^{226}$ Indeed, for an agency effectively to "ignore its institutional memory, would be to divest itself of critical resources in carrying out congressional designs."227 From this perspective, even if legislative history should play no (or very little) role in judicial statutory interpretation, the executive use of such information may be entirely appropriate, even obligatory.

Although I find Professor Strauss's argument compelling, and although agencies do, in fact, often rely on legislative history and other extratextual sources of meaning, ${ }^{228}$ a full evaluation of that reliance is beyond the scope of this Article. Instead, I seek only to emphasize that the frequency with which an agency or other executive actor may legitimately employ the avoidance canon depends, in part, on whether it is legitimate for the agency to rely on legislative history and other extratextual sources of statutory meaning. ${ }^{229}$ The status of the avoidance canon in the executive branch, in other words, is entwined with the status of other interpretive methods.

The second qualification to the point about extratextual sources trumping the avoidance canon is that the trump works only for non-clear statement versions of avoidance. As discussed above, the constitutional enforcement theory of avoidance could, but need not, entail a literal clear statement requirement. ${ }^{230}$ That variation is significant here be-

226. See Strauss, Agency Interpretation, supra note 2, at 329-35.

227. Mashaw, Paradox of Deference, supra note 2, at 511 .

228. As Bernard Bell notes, "In construing statutes, agencies certainly take into account non-legislative statements of members of Congress," including letters and other correspondence from individual members of Congress. Bell, supra note 27, at $105 \mathrm{n} .1$. He cites a number of examples, including Trans Union Corp., No. D-9255, 1993 WL 767039 (Fed. Trade Comm'n Sept. 20, 1993) (relying on statement and post-enactment letter from Senator Proxmire to FTC to limit otherwise plain meaning of statute), and Cable Television Act of 1992-Program Distribution and Carriage Agreements, 60 Fed. Reg. 3099,3100 n.8 (Jan. 13, 1995) (relying on four different letters from members of Congress, taking conflicting positions on meaning of statute, to establish that statute is ambiguous).

229. "Other extratextual sources" might include evidence about current congressional or committee preferences, as opposed to those of the enacting Congress. As J.R. DeShazo and Jody Freeman have suggested, Congress may be "best viewed as a collection of rivals who vie for control over power delegated to agencies." J.R. DeShazo \& Jody Freeman, The Congressional Competition to Control Delegated Power, 81 Tex. L. Rev. 1443, 1446 (2003). Such competition tends to occur "among at least three principals: the enacting [congressional] majority, the current majority, and the current members of oversight committees." ld. I take no position on whether it is legitimate for an agency to privilege the wishes of the current Congress or committee over those of the enacting Congress. Rather, 1 simply note that to the extent an agency's more detailed knowledge of statutory purpose or congressional intent is based on the wishes of either of those contemporary constituencies, my point about extratextual information trumping facial statutory ambiguity is contingent on our separately accepting the legitimacy of relying on those sources.

230. See supra text accompanying notes 110-118. 
cause a clear statement rule, at least in its most robust form, is effectively a rule of specific drafting. 1t provides that constitutional-doubts-raising interpretations must be avoided unless compelled by "the affirmative intention of the Congress clearly expressed." 231 Thus, even if an executive branch official is in a position to know with certainty that Congress intended to enact a constitutionally doubtful statute, a clear statement version of the avoidance canon would dictate ignoring Congress's intended meaning unless it is memorialized in express, unambiguous statutory language. In such circumstances, extratextual sources of meaning are irrelevant; no amount of extratextual clarity can conjure a clear textual statement. In that respect, the clear statement version of avoidance is rather at odds with the rule that the avoidance canon only applies in cases of statutory ambignity. Here again, though, my purpose is not to argne that clear statement avoidance is necessarily unjustifiable. Rather, I seek only to emphasize that the consequence of variation in interpretive contextin particular, the availability of extratextual sources-depends on whether avoidance is understood as a true clear statement rule.

\section{B. Examples of Inappropriate Avoidance}

My aim in the previous subsection was to show that, at least in some circumstances, the institutional posture of executive branch statutory interpretation can determine whether there is room for the avoidance canon. To illustrate the point, I turn now to some specific occasions when recourse to the avoidance canon would appear inappropriate. 1 discuss three examples from three distinct phases of the legislative process: while a bill is still pending before Congress, when an enrolled bill is presented to the President for his signature, and after the bill has become law.

1. Needless Avoidance in Bill Comments by the Office of Legal Counsel. In some circumstances, the posture of the interpretation makes it unnecessary to employ ambiguity-managing devices like the avoidance canon. Such is the case with OLC's "bill comment" practice. As part of this practice, OLC reviews bills introduced in Congress for potential constitutional problems. When a potential constitutional problem arises, OLC produces a short bill comment identifying the problem. Another executive branch office then puts the bill comment together with policy commentary from other offices and forwards the whole package on to Congress. ${ }^{232}$

Not infrequently in the bill comment process, OLC reviews a bill containing ambiguous language where one potential reading could raise

231. NLRB v. Catholic Bishop, 440 U.S. 490,501 (1979) (emphasis added) (internal quotation marks omitted) (quoting McCulloch v. Sociedad Nacional de Marineros, 372 U.S. 10, 22 (1963)).

232. See Pillard, supra note 2, at 711-12 (describing bill comment process). 
the kind of constitutional concerns triggering the avoidance canon. ${ }^{233}$ It is unclear how often OLC applies avoidance in such circumstances, as "[a] large mass of bill comments remains unpublished" and inaccessible to the public. ${ }^{234}$ Yet it would be difficult to justify ever employing avoidance in this context. Because the bill is not yet enacted, and because bill comments are intended to facilitate a constructive dialogue between the executive and legislative branches, it is hard to see what legal value would be served by employing avoidance.

A better practice would involve three steps. First, OLC should decide how best to read the statute without regard to avoidance. Second, to the extent its preferred reading might reasonably be thought to raise constitutional doubts, and to the extent a doubts-avoiding construction is sufficiently plausible, OLC should inform Congress that, if the bill is enacted in its current form, reviewing courts and executive actors will probably adopt the doubts-avoiding construction. Third, and critically, OLC should then provide a full analysis of the constitutional concerns raised by its otherwise preferred construction, reaching a conclusion, to the extent possible, about whether that construction is constitutional. With the benefit of that full analysis, Congress could then decide how to proceed. If OLC concludes that any constitutional concerns raised by the preferred reading are ultimately unavailing, Congress could elect to amend the statute so that it unambiguously produced that reading, reasonably confident that the statute would likely survive any constitutional challenges. ${ }^{235}$ If, on the other hand, OLC concludes that the preferred reading of the bill is probably unconstitutional, Congress could attempt to amend the statute in a way that both addressed the constitutional concerns and advanced its underlying policy aims. In either case, the legislative process would be enhanced far more than if OLC were to evade the constitutional issue by means of the avoidance canon.

In short, bill comments are a way for OLC to cooperate in the legislative process. It would frustrate the spirit of that cooperation and produce no countervailing benefit under the constitutional enforcement theory for OLC to apply the avoidance canon in its bill comments.

2. Changing the Legislative Bargain in Presidential Signing Statements. When an enrolled bill arrives at the White House for the President's signature, another interpretive moment arrives with it: The President may issue a signing statement. Presidents have long issued pronouncements

233. See, e.g., Appropriations Limitation for Rules Vetoed by Congress, 4B Op. Off. Legal Counsel 731, 732 n.3, 734 (1980).

234. Pillard, supra note 2, at 713 .

235. Of course, OLC would not be able to guarantee that the courts would resolve the constitutional issues in the same way, and a prudent Congress would take into account the risk of judicial-executive disagreement in any particular case. 
regarding the bills they sign into law. ${ }^{236}$ The pronouncements may serve a variety of purposes, some of which are of no legal consequence. ${ }^{237}$ Other times, however, Presidents may use signing statements for substantive purposes. One of those purposes is to invoke principles of constitutional avoidance and thereby limit the reach or effect of the bill.

As explained in an OLC opinion from early in the Clinton Administration, a signing statement "may put forward a 'saving' construction of the bill, explaining that the President will construe it in a certain manner in order to avoid constitutional difficulties. This ... is analogous to the Supreme Court's practice of construing statutes, if possible, to avoid . . deciding difficult constitutional questions." ${ }^{238}$ The use of avoidance-style reasoning in signing statements has a fairly established history, ${ }^{239}$ although recent scholarship suggests that the Bush Administration has taken the practice to a new level. ${ }^{240}$ Such frequent, aggressive use of avoidance raises questions about whether it is being deployed inappropriately.

As discussed above, executive actors may often face circumstances where, owing to their past negotiations and other interactions with Congress, they know precisely what was, and was not, intended by a particular statutory provision. ${ }^{241}$ The avoidance canon becomes inapplicable in

236. See The Legal Significance of Presidential Signing Statements, 17 Op. Off. Legal Counsel 131, 132-34 \& nn.3-4 (1993) (discussing examples from Truman, Kennedy, and Lyndon Johnson administrations).

237. For example,

signing statements have frequently been used ... to applaud or criticize the policy behind certain provisions, to advise Congress how the President will respond to future legislation, to condemn practices such as attaching riders to omnibus bills, to congratulate members of Congress or the public who have assisted in the bill's passage, and so forth.

ld. at 131 n. 1 .

238. Id. at 133 (citation omitted).

239. See, e.g., Statement by the President upon Approval of Bill Amending the Mutual Security Act of 1954, 1959 Pub. Papers 549 (July 24, 1959) (stating "I have signed this bill on the express premise that the three amendments relating to disclosure are not intended to alter and cannot alter the recognized Constitutional duty and power of the Executive with respect to the disclosure of information, documents, and other materials" and concluding that "any other construction of these amendments would raise grave Constitutional questions under the historic Separation of Powers Doctrine").

240. See Phillip J. Cooper, George W. Bush, Edgar Allan Poe, and the Use and Abuse of Presidential Signing Statements, 35 Presidential Stud. Q. 515, 520 (2005) ("The administration of George W. Bush has quietly, systematically, and effectively developed the presidential signing statement to regularly revise legislation and pursue its goal of building the unified executive."); id. at 521 (reporting that from early 2001 to late 2004, President Bush issued 108 signing statements raising 505 constitutional challenges to various provisions of legislation being signed into law); see also Charlie Savage, Bush Challenges Hundreds of Laws, Boston Globe, Apr. 30, 2006, at A1 ("President Bush has quietly claimed the authority to disobey more than 750 laws enacted since he took office, asserting that he has the power to set aside any statute passed by Congress when it conflicts witb his interpretation of the Constitution.").

241. See supra Part IV.A. 
such circumstances, because the executive officials' intimate knowledge of congressional intent and purpose removes the statutory ambiguity needed to trigger the canon. Thus in the signing statement context, if the bill on the President's desk was the subject of close negotiations between executive and congressional leaders, the President may know precisely what is meant by each provision. If a court or other uninvolved third party were to read the bill, it might deem certain provisions ambiguous. But the executive branch's relationship to the bill is different-not that of an uninvolved third party treating the text like a cold record, but that of an intimately involved participant in the production of the text itself. ${ }^{242}$

The issue for the use of avoidance in signing statements, then, is whether the President's potentially more detailed, intimate familiarity with the statute's intended meaning and purpose removes the ambiguity needed to trigger avoidance. Consider President Bush's statement on signing the 2006 Defense Appropriations bill. The bill included the McCain Amendment, which provided that "[n]o individual in the custody or under the physical control of the United States Government, regardless of nationality or physical location, shall be subject to cruel, inhuman, or degrading treatment or punishment." ${ }^{443}$ That fairly absolutist language notwithstanding, President Bush's signing statement reserved substantial leeway for the executive branch: "The executive branch shall construe [the relevant provisions] relating to detainees [ ] in a manner consistent with the constitutional authority of the President to supervise the unitary executive branch and as Commander in Chief and consistent with the constitutional limitations on the judicial power ...."244 Although the statement was not explicit on this point, the premise of the reservation seems to be that serious constitutional questions would be raised by a categorical statutory prohibition on certain conduct that a

242. See generally Clinton Rossiter, The American Presidency 110 (2d ed. 1960) (discussing modern Presidents' extensive involvement in legislative process).

243. Detainee Treatment Act of 2005, H.R. 2863, 109th Cong. $\$ 1003$ (a) (2005) (enacted). The McCain Amendment further provides that

"cruel, inhuman, or degrading treatment or punishment" means the cruel, unusual, and inhumane treatment or punishment prohibited by the Fifth, Eighth, and Fourteenth Amendments to the Constitution of the United States, as defined in the United States Reservations, Declarations and Understandings to the United Nations Convention Against Torture and Other Forms of Cruel, Inhuman or Degrading Treatment or Punishment done at New York, December 10, 1984.

1d. $\S 1003(d)$. In addition, a separate provision directs that "[n]o person in the custody or under the effective control of the Department of Defense or under detention in a Department of Defense facility shall be subject to any treatment or technique of interrogation not authorized by and listed in the United States Army Field Manual on Intelligence 1nterrogation." 1d. § 1002(a).

244. Statement on Signing the Department of Defense, Emergency Supplemental Appropriations to Address Hurricanes in the Gulf of Mexico, and Pandemic Influenza Act 2006, 41 Weekly Comp. Pres. Doc. 1918, 1919 (Dec. 30, 2005). 
President might order in his capacity as Commander in Chief. ${ }^{245}$ To avoid those concerns, the signing statement read an implicit exception into the McCain Amendment's prohibitions.

As with the Bybee Memorandum, ${ }^{246}$ the McCain Amendment signing statement was premised on a highly controversial vision of expansive, unilateral presidential power under Article Il of the Constitution. Yet as with the Bybee Memorandum, I want to set aside the problems with the underlying constitutional analysis and focus specifically on the avoidance canon. Here, the question is whether the President's invocation of avoidance-style reasoning in the signing statement was an appropriate response to ambiguous legislation, or was instead an attempt effectively to rewrite the statute. Even if one were to look only at the rather unambiguous text of the McCain Amendment, this could well look like a case of statutory rewriting, not interpretation. The point I want to stress, however, is that the President had much more than the text to guide him, and that the extratextual evidence makes the President's signing statement even harder to justify than if he had only the text before him.

Senator McCain, the principal sponsor of the eponymous Amendment, made clear in public statements that a fundamental aim of the Amendment was to prohibit categorically the torture and other cruel, inhuman, or degrading treatment of detainees in the war on terror. ${ }^{247}$ The Administration understood the McCain Amendment to do just that, and

245. I concede that this reading of the signing statement is somewhat speculative. The statement does not expressly conclude that any aspect of the McCain Amendment would necessarily raise serious constitutional concerns if construed in a particular way, and it is at least theoretically possible that the executive branch will never rely on avoidance to narrow or resist any particular application of the McCain Amendment. Cf. Curtis A. Bradley \& Eric A. Posner, Presidential Signing Statements and Executive Power 21, (Chi. Law Sch. Pub. Law \& Legal Theory Research Paper Series, Working Paper No. 133, 2006) available at http://papers.ssrn.com/sol3/papers.cfm?abstract_id=922400 (on file with the Columbia Law Review) ("As far as we have found, the critics of the Bush administration's use of signing statements have not identified a single instance where the Bush administration followed through on the language in the signing statement and refused to enforce the statute as written."). Yet it seems unlikely that the relevant language in the President's signing statement is nothing more than substanceless boilerplate. Certainly, it has not generally been received as such. See, e.g., Sanford Levinson, The Deepening Crisis of American Constitutionalism, 40 Ga. L. Rev. 889, 890-91 (2006) (describing McCain Amendment signing statement as "clear[]" example of "the Bush Administration's continued assertions that it simply does not recognize any congressional capacity to control presidential decisionmaking regarding methods of interrogation of ostensible enemies of the United States," and citing various commentators taking similar positions).

246. See supra text accompanying notes I79-186.

247. See, e.g., 15I Cong. Rec. SI 1063-64 (daily ed. Oct. 5, 2005) (statement of Sen. McCain) (noting that " $\mathrm{t}] \mathrm{he}$ prohibition against cruel, inhumane, and degrading treatment has been a longstanding principle in both law and policy in the United States" but that recently "confusion about the rules [had] become[ ] rampant again," with "so many differing legal standards and loopholes that our lawyers and generals are confused"; proposing McCain Amendment to "restore clarity on a simple and fundamental question: Does America treat people inhumanely? My answer is no. And from all I have seen, America's answer has always been no"). 
for that reason spent several months resisting and even threatening to veto it. ${ }^{248}$ The impasse was ultimately broken when the Administration changed course and decided to support the Amendment, but not because of any suggestion that it could be construed to avoid imposing substantial limitations on the executive branch. Rather, the change came partly because there were clearly enough votes in Congress to overcome a veto, ${ }^{249}$ and partly because the Administration had obtained a number of concessions on related matters, including a set of provisions severely restricting the federal courts' jurisdiction to review the detention of enemy combatants at Guantanamo Bay. ${ }^{250}$ In other words, the McCain Amendment became law as part of a negotiated bargain whose cost to the executive branch was the Amendment's categorical prohibition on cruel, inhuman, or degrading treatment of prisoners. The President himself appeared to accept this bargain at a press conference announcing his newfound support for the Amendment. ${ }^{251}$

Viewed in this context, the President's subsequent signing statement reads like a unilateral alteration of the legislative bargain. As Senators McCain and Warner explained in a public response to the signing statement, "the President understands Congress's intent in passing by very large majorities legislation governing the treatment of detainees included in the 2006 Department of Defense Appropriations and Authorization bills. The Congress declined when asked by administration officials to include a

248. See Charles Babington \& Shailagh Murray, Senate Supports Interrogation Limits, Wash. Post, Oct. 6, 2005, at A1; Eric Schmitt, Senate Moves to Protect Military Prisoners Despite Veto Threat, N.Y. Times, Oct. 6, 2005, at A22.

249. See 151 Cong. Rec. S14254 (daily ed. Dec. 21, 2005) (Rollcall Vote No. 366) (showing 93 out of 100 Senate votes for adoption of H.R. Rep. No. 109-359 (2005) (Conf. Rep.)); id. at H12268-69 (daily ed. Dec. 18, 2005) (Roll No. 669) (showing 308 out of 435 House votes for adoption of H.R. Rep. No. 109-359 (2005) (Conf. Rep.)); id. at S11256 (daily ed. Oct. 7, 2005) (Rollcall Vote No. 254) (showing 97 out of 100 Senate votes for passage of H.R. 2863, 109th Cong. (2005) (enacted), as amended); id. at $\$ 11114$ (daily ed. Oct. 5, 2005) (Rollcall Vote No. 249) (showing 90 out of 100 Senate votes for S. Amendment No. 1977, McCain Amendment).

250. The provisions narrowing the courts' jurisdiction were introduced in the Senate on November 14, 2005, as the McCain Amendment was being considered by Congress. See S. Amendment 2524 to S. 1042, 151 Cong. Rec. S12771-72 (daily ed. Nov. 14, 2005) (enacted).

251. See Josh White, President Relents, Backs Torture Ban, Wash. Post, Dec. 16, 2005, at Al (quoting President Bush as saying “[w]e've been happy to work with [Senator McCain] to achieve a common objective, and that is to make it clear to the world that this government does not torture and that we adhere to the international convention [on] torture, whether it be here at home or abroad" (internal quotation marks omitted)). Admittedly, in referring only to torture and not to "cruel, inhuman, or degrading treatment," the President did not explicitly embrace the precise terms of the McCain Amendment. But neither did he expressly withhold support for any part of the Amendment. Given his claim to have "been happy to work with [Senator McCain] to achieve a common objective," a reasonable listener would surely have understood the President's statement as an expression of support for the McCain Amendment, not a warning that he would soon use a signing statement to substantially narrow the Amendment's reach. 
presidential waiver of the restrictions included in our legislation." 252 Thus, even assuming that the bare text of the McCain Amendment might permit the narrowing construction announced in the President's signing statement (which it almost certainly cannot), the Administration's additional familiarity with-indeed, intimate involvement in-the negotiations that produced the Amendment leaves no room for doubt as to its meaning. And in the absence of any actual uncertainty about the Amendment's meaning, the signing statement's avoidance-inspired construction is indefensible.

This is not to say that avoidance has no place in presidential signing statements. In circumstances where no executive official was especially involved in the framing of a particular provision or where a particular interpretive issue never arose until the signing stage, ${ }^{253}$ the President may not be in a position to supplement the bill's bare text with contextual understanding of its purpose. And if the text otherwise meets the criteria for avoidance-that is, textual ambiguity and serious constitutional concerns attending the otherwise preferred reading-it may be perfectly appropriate for the President to invoke the avoidance canon in a signing statement, in order to clarify his own good faith understanding of the bill he is signing. But in circumstances where the Administration's more detailed, firsthand knowledge about the bill removes all ambiguity as to its meaning, avoidance has no role to play. Indeed, invoking avoidance in those circumstances is tantamount to rewriting the legislation itself. And that the President may not do. ${ }^{254}$

3. Institutional Amnesia in Interpretations of Existing Statutes. - Signing statements are not the only occasions where the executive's familiarity with, and involvement in, the legislative history of a particular enactment may affect the propriety of employing constitutional avoidance. The same can take place just as readily when executive actors are called upon to construe already enacted legislation.

Consider, for example, President Bush's authorization of the National Security Agency (NSA) to engage in the warrantless gathering of "signals intelligence" within the United States, from communications in-

252. Press Release, John V. Warner \& John McCain, Senators, Statement on Presidential Signing Detainee Provisions (Jan. 4, 2006), available at http://mccain.senate. gov/index.cfm?fuseaction=Newscenter.ViewPressRelease\&Content_id=1634 (on file with the Colmbia Law Review) (emphasis added).

253. I take no position here on the frequency of such circumstances.

254. See The Legal Significance of Presidential Signing Statements, supra note 236, at 137 (" $[\mathrm{I}] \mathrm{t}$ is arguable that "by reinterpreting those parts of congressionally enacted legislation of which he disapproves, the President exercises unconstitutional line-item veto power.' " (quoting Marc N. Garber \& Kurt A. Wimmer, Presidential Signing Statements as Interpretations of Legislative Intent: An Executive Aggrandizement of Power, 24 Harv. J. on Legis. 363, 376 (1987))); Constitutionality of Line-Item Veto Proposal, 9 Op. Off. Legal Counsel 28, 30 (1985) ("[U]nder the system of checks and balances established by the Constitution, the President has the right to approve or reject a piece of legislation, but not to rewrite it or change the bargain struck by Congress in adopting a particular bill."). 
volving United States citizens. ${ }^{255}$ One of the core legal issues in this controversy is whether the surveillance complies with the Foreign Intelligence Surveillance Act (FISA), which lays out the basic legal structure governing electronic surveillance within the United States. ${ }^{256}$ As a general matter, FISA authorizes electronic surveillance within the United States only upon certain specified showings, and only with a court-issued warrant. ${ }^{257}$ Beyond that, FISA makes it a criminal offense to engage in any electronic surveillance not authorized by statute, ${ }^{258}$ and another provision in the federal code specifies that FISA and certain other provisions governing wiretaps for criminal investigation are the "exclusive means by which electronic surveillance . . may be conducted."259

Shortly after news broke that the President had authorized the surveillance in question, ${ }^{260}$ the Justice Department offered a formal defense of the program in a letter addressed to members of the House and Senate Intelligence Committees. ${ }^{261}$ The letter was later supplemented by a much more detailed white paper sent to the Senate majority leader, ${ }^{262}$ though the basic argument remained the same. It had two essential parts. First, the Department argued that the President has substantial constitutional authority to order warrantless intelligence surveillance even within the United States. ${ }^{263}$ Second, and more pertinently for present purposes, the Department asserted that the Authorization for Use of Military Force (AUMF) of September I8, 2001 "confirms and supplements" the President's inherent constitutional authority in this area. ${ }^{264}$

The AUMF empowers the President to "use all necessary and appropriate force against those nations, organizations, or persons" he determines to be responsible for the September 11 attacks, but says nothing

255. For an explanation of "signals intelligence," see Memorandum from Elizabeth B. Bazan \& Jennifer K. Elsea, Legislative Attorneys, Congressional Research Serv., Presidential Authority to Conduct Warrantless Electronic Surveillance to Gather Foreign Intelligence Information $1 \mathrm{n} .1$ (Jan. 5, 2006), available at http://www.fas.org/sgp/crs/intel/m010506. pdf (on file with the Columbia Law Review).

256. See 50 U.S.C. $\$ \$ 1801-1811$ (2000).

257. Id. $\$ 1805$. FISA does permit warrantless domestic electronic surveillance during wartime, but only for the first fifteen days of a war. See id. $\S 1811$.

258. ld. § 1809 (a) (1).

259. 18 U.S.C. $\$ 2511(2)(f)(2000)$.

260. The New York Times broke the story in late 2005. See James Risen \& Eric Lichtblau, Bush Lets U.S. Spy on Callers Without Courts, N.Y. Times, Dec. 16, 2005, at Al.

261. Letter from William E. Moschella, Assistant Attorney Gen., U.S. Dep't of Justice, to Pat Roberts, Chairman, Senate Select Comm. on Intelligence, et al. (Dec. 22, 2005), available at http://fl1.findlaw.com/news.findlaw.com/hdocs/docs/nsa/dojnsa122205ltr. pdf (on file with the Columbia Law Review) [hereinafter DOJ Letter].

262. See U.S. Dep't of Justice, Legal Authorities Supporting the Activities of the National Security Agency Described by the President (2006), available at http://fll.find law.com/news.findlaw.com/hdocs/docs/nsa/dojnsal1906wp.pdf (on file with the Columbia Law Review) [hereinafter DOJ White Paper].

263. See DOJ Letter, supra note 261, at 2; DOJ White Paper, supra note 262, at 6-10. 264. DOJ Letter, supra note 261 , at 2; DOJ White Paper, supra note 262 , at 10. 
whatever about surveillance within the United States. ${ }^{265}$ On its face, therefore, the Justice Department's AUMF argument would appear to conflict with FISA's express identification of the statutory provisions setting forth "the exclusive means" for conducting domestic electronic surveillance. ${ }^{266}$

The Justice Department attempted to manage the conflict in two ways. First, it relied upon the Supreme Court's construction of the AUMF in Hamdi v. Rumsfeld. ${ }^{267}$ In that case, a divided Court held that the AUMF authorized the executive detention, without charge, of a U.S. citizen alleged to be an enemy combatant. ${ }^{268}$ in particular, Justice O'Connor's plurality opinion concluded that although the AUMF does not mention detention, its authorization of "all necessary and appropriate force" satisfies a separate federal statute known as the Non-Detention Act, ${ }^{269}$ which provides that " $[\mathrm{n}] \mathrm{o}$ citizen shall be imprisoned or otherwise detained by the United States except pursuant to an Act of Congress." 270 1t was that conclusion that the Justice Department relied on in its defense of the NSA surveillance program. Specifically, the Department argued that if the AUMF's authorization of "all necessary and appropriate force" satisfies the statutory requirement that citizens be detained only pursuant to a federal statute, it must also be enough to overcome FISA's identification of the "exclusive means" for conducting electronic surveillance. ${ }^{271}$

The Hamdi analogy is unpersuasive, however. First, detaining enemy combatants captured on the battlefield would seem to be a much more fundamental and traditional incident to war-and thus more readily encompassed in the AUMF's provision for "all necessary and appropriate force"-than is monitoring the communications of U.S. citizens within the United States. ${ }^{272}$ Second, and more importantly, the Non-Detention Act's requirement that U.S. citizens be detained only "pursuant to an Act of Congress" does not, on its face, require an express statement of congressional authorization. ${ }^{273}$ FISA, in contrast, is explicit in its identifica-

265. Authorization for Use of Military Force (AUMF), Pub. L. No. 107-40, § 2(a), 115 Stat. 224, 224 (2001).

266. 18 U.S.C. $\$ 2511$ (2)(f) (2000).

267. 542 U.S. 507 (2004) (plurality opinion).

268. For a discussion of the positions taken by the various opinions in the case, see Morrison, supra note 157 , at 417-26.

269. See Hamdi, 542 U.S. at 517-18 (O'Connor, J., plurality opinion) (internal quotation marks omitted) (quoting AUMF $\$ 2(a), 115$ Stat. at 224).

270. 18 U.S.C. $\$ 4001$ (a).

271. See DOJ Letter, supra note 261, at 3; DOJ White Paper, supra note 262, at 12-13.

272. See David L. Franklin, Popular Constitutionalism as Presidential Constitutionalism? Some Cautionary Remarks, 81 Chi.-Kent L. Rev. (forthcoming Oct. 2006), available at http://papers.ssrn.com/sol3/papers.cfm?abstract_id $=888911$ (manuscript at 20, on file with the Columbia Law Review) ("[D]etaining active enemy combatants captured on a battlefield abroad is inherent in the use of force for purposes of war in a way that eavesdropping on American citizens within the United States is not.").

273. I have, however, expressed my agreement with Justice Souter's separate opinion in Hamdi, in which he made a forceful case that the Non-Detention Act, in light of its 
tion of the "exclusive means" for conducting electronic surveillance. ${ }^{274}$ To conclude that the AUMF satisfies the Non-Detention Act is to conclude that it provides the statutory authority required by that Act; to conclude that the AUMF overcomes FISA is to make the very different determination that it impliedly repeals FISA's express exclusivity provision. ${ }^{275}$ The significance of that distinction is confirmed by the Supreme Court's recent decision in Hamdan v. Rumsfeld. ${ }^{276}$ There, the Court cited Hamdi for the proposition that the AUMF "activated the President's war powers," 277 but then held that such activation did not impliedly repeal the limitations on military commissions set forth in the preexisting Uniform Code of Military Justice (UCMJ). ${ }^{278}$ If Hamdi does not support reading the AUMF to repeal or amend the UCMJ, surely it likewise does not support reading the AUMF to repeal or amend FISA. ${ }^{279}$

In any event, it is the Justice Department's second attempt to overcome the tension between FISA and the AUMF that is of principal interest here. For that attempt, the Department turned to the avoidance canon:

Some might suggest that FISA could be read to require that a subsequent statutory authorization must come in the form of an amendment to FISA itself. But under established principles of statutory construction, the AUMF and FISA must be construed in harmony to avoid any potential conflict between FISA and the President's Article II authority as Commander in Chief. Accordingly, any ambiguity as to whether the AUMF is a statute

history and purpose, should be construed to impose a clear statement requirement, and that the AUMF did not satisfy such a requirement. See Morrison, supra note 157, at 421, 449-50.

274. 18 U.S.C. $\$ 2511(2)(f)$.

275. The Supreme Court has long made clear that repeals by implication are disfavored. See, e.g., Branch v. Smith, 538 U.S. 254, 273 (2003) ("We have repeatedly stated . . . that absent 'a clearly expressed congressional intention,' . . 'repeals by implication are not favored." (quoting Morton v. Mancari, 417 U.S. 535, 551 (1974); Universal Interpretive Shuttle Corp. v. Wash. Metro. Area Transit Comm'n, 393 U.S. 186, 193 (1968))); Ex parte Yerger, 75 U.S. (8 Wall.) 85, 105 (1868) ("Repeals by implication are not favored. They are seldom admitted except on the ground of repugnancy; and never, we think, when the former act can stand together with the new act.").

276. 126 S. Ct. 2749 (2006).

277. 1d. at 2755 .

278. Id. (" $[\mathrm{T}]$ here is nothing in the AUMF's text or legislative history even hinting that Congress intended to expand or alter the authorization set forth in UCMJ Art. 21.")

279. The Justice Department, however, reacted to Hamdan by insisting that the decision does not undermine-or even affect-its reliance on Hamdi. See Letter from William E. Moschella, Assistant Attorney Gen., U.S. Dep't of Justice, to Charles Schumer, Senator, Senate Comm. on Judiciary 1 (July 10, 2006), available at http://lawculture.blogs. com/lawculture/files/NSA.Hamdan.response.schumer.pdf (on file with the Columbia Law Review) ("Our initial impression is that the Court's opinion [in Hamdan] does not affect our analysis of the Terrorist Surveillance Program for several reasons."); id. at 2 ("Because the Terrorist Surveillance Program implicates a statutory regime analogous to the one at issue in Hamdi we believe that the reasoning of Hamdi is far more relevant to the Terrorist Surveillance Program than the reasoning of Hamdan." (citation omitted)). 
that satisfies the requirements of FISA and allows electronic surveillance in the conflict with al Qaeda without complying with FISA procedures must be resolved in favor of an interpretation that is consistent with the President's long-recagnized [constitutional] authority. ${ }^{280}$

The structure of the avoidance argument here is somewhat unusual. The contention is not that avoidance requires reading FISA itself to permit the surveillance in question. Rather, as Attorney General Gonzales made clear in a subsequent letter to the Chairman of the Senate Judiciary Committee, the argument is that "FISA is best read to allow a statute such as the [AUMF] to authorize electronic surveillance outside FISA procedures and, in any case, that the canon of constitutional avoidance requires adopting that interpretation." ${ }^{81}$ This is an attempt, in other words, to employ the avoidance canon to manage ambiguity that the Justice Department claims to find somewhere between FISA and the AUMF.

As with the Bybee Memorandum and the McCain Amendment signing statement, there are a number of difficulties with the use of avoidance here. For one thing, the underlying constitutional theory of exclusive and inviolable executive power is extremely aggressive. 282 Once again, though, the underlying constitutional analysis is not my main concern here. Instead, I want to stress a problem relating to the executive's knowledge of legislative history, congressional purpose, and statutory context.

280. DOJ Letter, supra note 261 , at 4 (citing Zadvydas v. Davis, 533 U.S. 678, 689 (2001), and INS v. St. Cyr, 533 U.S. 289, 300 (2001), for avoidance point).

281. Letter from Alberto R. Gonzales, Attorney Gen., to Arlen Specter, Chairman, Senate Comm. on the Judiciary 5 (Feb. 28, 2006) (on file with the Columbia Law Review). The Justice Department's longer white paper elaborated on this argument in considerable detail. See DOJ White Paper, supra note 262, at 28-36. But it also went further, and concluded that "if an interpretation of FISA that allows the President to conduct the NSA activities were not fairly possible, FISA would be unconstitutional as applied in the context of this congressionally authorized armed conflict." Id. at 35 (internal quotation marks omitted). At that point, the white paper's analysis reverted from modern avoidance back to classical avoidance. That move does not affect the analysis here, however. True, as I discussed in Part III.B, the difference between classical and modern avoidance can be important when considering the general theoretical justification for the executive use of the canon. But both versions of avoidance require statutory ambiguity, and my point here is that, especially in light of the information available to executive branch leaders, FISA and the AUMF lack that ambiguity.

282. For another, FISA appears utterly lacking in the kind of facial ambiguity normally required to trigger the avoidance canon. Indeed, it is difficult to imagine how FISA and related provisions could be any clearer on the point that the statutory provisions they enumerate are the "exclusive means" for conducting the kind of surveillance at issue here. 18 U.S.C. $\$ 2511(2)$ (f) (2000). These and other problems with the Justice Department's argument are discussed in a letter submitted to Congress by several leading constitutional law scholars and former government officials. See Letter from Curtis A. Bradley, Richard \& Mary Horvitz Professor of Law, Duke Univ., et al., to Bill Frist, Majority Leader, U.S. Senate, et al. (Jan. 9, 2006), available at http://cdt.org/security/20060109 legalexpertsanalysis.pdf (on file with the Columbia Law Review), reprinted in N.Y. Rev. Books, Feb. 9, 2006, at 42. 
To put the point bluntly, it appears that leaders in the White House and the Justice Department knew that, in the period immediately before and shortly after the AUMF was enacted, the congressional leadership did not view the AUMF as authorizing the surveillance in question. Just before the Senate voted on the AUMF, the White House reportedly sought to insert the words "in the United States and" into the resolution, so that it would authorize the President to "use all necessary and appropriate force in the United States and against those nations, organizations, or persons" responsible for the September 11 attacks. ${ }^{283}$ But the Senate leadership refused, apparently on the grounds that it did not want to grant the President expansive powers within the United States. ${ }^{284}$

Later in the fall of 2001, the Bush Administration sought and obtained a number of amendments to FISA in the USA PATRIOT Act. ${ }^{285}$ The Administration did not, however, formally request an amendment to authorize the surveillance at issue here. The reason, according to Attorney General Gonzales in a December 2005 press conference, was that congressional leaders had advised the Administration that securing such an amendment "would be difficult, if not impossible."286 The Attorney General subsequently clarified his explanation by stating that the difficulty in question was not a matter of congressional unwillingness to provide the requisite authority, but concern that passing an amendment conferring the authority would compromise the secrecy of the government's surveillance efforts. ${ }^{287}$ That claim is somewhat difficult to credit as a mat-

283. The principal source for this point is an op-ed in the Washington Post by former Senate Majority Leader Tom Daschle. See Tom Daschle, Op-Ed., Power We Didn't Grant, Wash. Post, Dec. 23, 2005, at A21. It is easy to imagine that Senator Daschle might have had a political motive to write the editorial, given his evident opposition to the NSA spying program and, indeed, to many of the Bush Administration's policies. But in the time since the op-ed appeared, no one within or outside the Administration has publicly refuted its description of the events leading up to the AUMF's passage. Moreover, Senator Daschle's account is corroborated by a passage in a recent book by journalist Ron Suskind. See Ron Suskind, The One Percent Doctrine: Deep lnside America's Pursuit of Its Enemies Since 9/11, at 17 (2006) ("Minutes before the vote, the White House officials had pressed for even more-after 'use all necessary and appropriate force,' they wanted to insert 'in the United States,' to, essentially, grant war powers to anything a president deigned to do within the United States. Senators shot that down.").

284. See Daschle, supra note 283.

285. See, e.g., Pub. L. No. 107-56, § 207, 115 Stat. 272, 282 (2001) (amending 18 U.S.C. $\$ 1824$ (d)(1) by doubling authorized time to search suspects to ninety days).

286. Press Release, White House, Press Briefing by Attorney General Alberto Gonzales and General Michael Hayden, Principal Deputy Director for National Intelligence (Dec. 19, 2005), available at http://www.whitehouse.gov/news/releases/2005/12/20051219-1. html (on file with the Columbia Law Review) [hereinafter Gonzales Press Conference]. The Attorney General's full statement containing the quoted language is as follows: "We have had discussions with Congress in the past-certain members of Congress-as to whether or not FISA could be amended to allow us to adequately deal with this kind of threat, and we were advised that that would be difficult, if not impossible."

287. See Press Release, Dep't of Homeland Sec., Remarks by Homeland Security Secretary Michael Chertoff and Attorney General Alberto Gonzales on the USA Patriot Act (Dec. 21, 2005), available at http://www.dhs.gov/dhspublic/display?content=5285 (on file 
ter of mere common sense. ${ }^{288}$ But in any event, the critical point for present purposes is that, even under the Attorney General's clarified explanation, the Administration knew that the statutory authorization was not forthcoming. ${ }^{289}$ Even if the leaders in the Administration believed that some members of Congress wanted to grant the authority if it could be done with adequate secrecy, a willingness to provide statutory authority is a far cry from statutory authority itself.

Even more problematically, it was apparently only after concluding that it could not obtain an amendment to FISA that the Administration decided to rely on the earlier-enacted AUMF. ${ }^{290}$ Yet there is no indication that Congress thought the AUMF authorized the warrantless surveillance in question. Indeed, had anyone in the congressional leadership viewed the AUMF that way, then presumably they would have responded to the Administration's inquiries about amending FISA by saying it was

with the Columbia Law Review) [hereinafter Gonzales Remarks] ("We were advised that it would be virtually impossible to obtain legislation of this type without compromising the program. And I want to emphasize the addition of, without compromising the program. That was the concern.").

288. The claim depends on two shaky premises. First, it presumes that amending FISA would have "tipped off" the targeted terrorists, and that in the absence of the tip the terrorists would have proceeded on the assumption that their telephone communications were effectively immune from surveillance. That seems unlikely. Surely the targeted terrorists have long proceeded on precisely the opposite assumption-that they are the targets of a wide array of global surveillance efforts by the United States and its allies. It would be folly to assume otherwise. See Richard A. Clarke \& Roger W. Cressey, Op-Ed., A Secret the Terrorists Already Knew, N.Y. Times, June 30, 2006, at A23 ("Terrorists have for many years employed nontraditional communications ... precisely because they assume that international calls . . . are monitored not only by the United States but by Britain, France, Israel, Russia and even many third-world countries.").

The other premise of the claim is that a statutory amendment would necessarily reveal the specific contents of the surveillance program it was authorizing. That, too, seems unlikely. Statutory authorization need not speak in specific terms about the precise mechanics of the surveillance. The Justice Department itself acknowledged this, insofar as it claimed that the vague and open-ended language of the AUMF authorized the surveillance in question. See DOJ Letter, supra note 261, at 2-3. If the AUMF itself did not intolerably "tip off" the terrorists, surely the same would be true if it were amended to provide, for example, that the President may "use all necessary and appropriate force against those nations, organizations, or persons [responsible for the September 11 attacks], including intercepting their communications within and without the United States."

289. See Gonzales Press Conference, supra note 286 (" $\left[W^{\top}\right]$ e were advised that [amending F1SA] would be difficult, if not impossible."); Gonzales Remarks, supra note 287 ("We were advised that it would be virtually impossible to obtain legislation of this type without compromising the program.").

290. As the Attorney General explained,

We've had discussions with members of Congress . . . about whether or not we could get an amendment to FISA, and we were advised that . . that was not something we could likely get, certainly not without jeopardizing the existence of the program. ... [S]o a decision was made that because we felt that the authorities were there, that we should continue moving forward with the program.

Gonzales Press Conference, supra note 286 (emphasis added). 
unnecessary, since the AUMF had already accomplished the task. But no one said that. Instead, as noted above, congressional leaders told the Administration that the statutory authorization it sought could not be provided.

If leaders of the executive branch had known nothing about the legislative history behind the various pieces of war on terror legislation enacted in the fall of 2001, it might have been legitimate for them to construe FISA and the AUMF as they did. But given what they knew, the construction seems exceedingly difficult to justify. As I have just described, leaders of the Justice Department and White House knew in late 2001 that Congress did not intend the AUMF to authorize warrantless electronic surveillance within the United States. That knowledge was the natural byproduct of the "incredibly dense network of relationships and shared activities" linking the legislative and executive branches in the lawmaking process. ${ }^{291}$ Whether or not a court would have access to-or credit-that knowledge in a litigated case, it was disingenuous for the executive branch to ignore it. Indeed, the Justice Department's use of the avoidance canon in this context seems to present a textbook case of the executive branch "ignor[ing] its institutional memory." 292

As Professor Strauss has explained, one of the benefits of legislative history in agency statutory interpretation is that it can help agency officials resist the importuning of political figures within the executive branch. ${ }^{293}$ Faced with demands from more overtly political leaders to construe a statute according to their political agenda, agency officials may seek to rely on a lengthy legislative history to show that the political reading is inconsistent with congressional intent and statutory purpose. ${ }^{294}$ Legislative history, in other words, provides a means of meeting politics with law. The other side of that same coin is that in cases where an executive actor construes a statute in a way that ignores accessible and known legislative history and other extratextual sources, there is reason to suspect that politics may have trumped law. The Justice Department's use of the avoidance canon to defend the NSA surveillance program may be just such a case. Whatever legitimate role politics has to play in the work of the executive branch, ${ }^{295}$ surely it is not a license to stretch the instruments of formal legal analysis beyond their capacity.

291. Rubin, supra note 218, at 586 .

292. Mashaw, Paradox of Deference, supra note 2, at 511.

293. See Strauss, Agency lnterpretation, supra note 2, at 335-40.

294. Conceiving of an agency's use of legislative history in these terms may thus provide at least a partial means of answering Professor Farina's call to "recognize the constant tendency of regulatory power to flow, centripetally, towards the head of the executive branch and [to] think deliberately and carefully about where to find counterbalance for this tendency." Cynthia R. Farina, Statutory Interpretation and the Balance of Power in the Administrative State, 89 Colum. L. Rev. 452, 527 (1989).

295. See supra text accompanying notes $17-20$. 
Finally, and separately, the NSA example highlights the need, discussed above, ${ }^{296}$ for adequate congressional notification. The NSA program had been in effect for a number of years by the time the press reported on it in late 2005. ${ }^{297}$ During that time, it appears that very few members of Congress knew of its existence. 298 Of those who did know, there is no indication of their being told that the Administration was relying on the avoidance canon to justify the program. ${ }^{299}$ ln a July 17, 2003 letter to Vice President Cheney, for example, Senator Rockefeller noted the "profound oversight issues" raised by the NSA program on which he, Senator Roberts, and a few others had just been briefed. ${ }^{300}$ He went on to state that,

[g]iven the security restrictions association with this information, and my inability to consult staff or counsel on my own, I feel unable to fully evaluate, much less endorse, these activities. ... Without more information and the ability to draw on any independent legal or technical expertise, I simply cannot satisfy lingering concerns raised by the briefing we received. ${ }^{301}$

The letter contains no acknowledgment that the Administration was justifying the surveillance program by claiming authorization from Congress itself, and it seems highly unlikely that any such statement was included in the briefing. Yet as discussed above, timely and appropriate notice to Congress is a critical predicate of the constitutional enforcement theory of avoidance. In the absence of such notice, the Justice Department's avoidance-based defense of the NSA program simply cannot get off the ground.

\section{ConClusion}

If debates about the methods of statutory interpretation are inevitably about the constitutional values underlying those methods, ${ }^{302}$ then my first aim in this Article has been to highlight the different values that arguably underlie the canon of constitutional avoidance. From there, 1 have shown that, depending on which of two sets of values one connects to the avoidance canon, executive use of the canon may or may not be theoretically justifiable. Under the conventional account of avoidance,

296. See supra Part III.E.

297. See Risen \& Lichtblau, supra note 260.

298. See Letter from John D. Rockefeller, IV, Vice Chairman, Senate Select Comm. on Intelligence, to Ricbard B. Cbeney, Vice President 1 (July 17, 2003), available at http:// thinkprogress.org/wp-images/upload/Intell.pdf (on file with the Columbia Law Review).

299. Other parts of the Justice Department's defense of the program, such as its reliance on the Supreme Court's 2004 decision in Hamdi $v$. Rumsfeld, obviously postdated the initiation of the program. See DOJ Letter, supra note 261, at 3; DOJ White Paper, supra note 262, at 2 .

300. See Letter from John D. Rockefeller to Richard B. Cheney, supra note 298, at 1 .

301. Id. at I-2.

302. See Jerry Mashaw, As If Republican Interpretation, 97 Yale L.J. 1685, 1686 (1988) ("Any theory of statutory interpretation is at base a theory about constitutional law."). 
which I have called the judicial restraint theory, the avoidance canon is inapt in the executive branch. Under an alternative account, which I have called the constitutional enforcement theory, the case for avoidance seems just as strong in the executive branch as in the courts.

Although my main object has been to consider executive branch statutory interpretation on its own, outside the shadow of judicial review, my conclusion about the constitutional enforcement theory yields at least one useful point for the debate about avoidance in the courts: Criticisms of judicial avoidance that stress intrusions on the executive branch's prerogative to interpret the $\operatorname{law}^{303}$ may be overstated. If the executive branch itself is properly expected to employ avoidance in a particular situation, then the judiciary's use of avoidance to reverse the executive's interpretation is simply the natural consequence of granting the courts final say in matters of strictly legal interpretation as opposed to discretionary policymaking. ${ }^{304}$

Yet even if executive branch avoidance is generally justifiable in theory, it may still be inappropriate in certain situations. Especially when an agency or other executive component interprets a statute it regularly administers and discusses with Congress, extratextual sources may resolve any facial ambiguity in the statute's language. In such circumstances, the avoidance canon has no work to do. Indeed, executive use of avoidance in those circumstances is not only unnecessary, but also inappropriate, and likely reflects a triumph of political machinations over legal principle. As I have shown, this flaw is evident in a number of executive uses of avoidance in issues relating to the war on terror.

In short, determining whether executive actors should use the avoidance canon requires attention to both theoretical justification and interpretive context. Examination of those factors reveals that, depending on the theory of avoidance one adopts and the relative information richness of the interpretive context, executive branch avoidance may well be appropriate in some circumstances. In that respect, the canon of constitutional avoidance, that much maligned yet still "cardinal principle" of judicial statutory interpretation, may have a home in the executive branch as well.

303. See Kelley, supra note 26, at 867-91.

304. 1 have in mind here the familiar distinction between the first and second steps of the Chevron framework, according to which a court first applies the conventional tools of statutory construction-including, the Supreme Court has instructed, the avoidance canon-before treating any remaining statutory ambiguity as an implicit delegation of policymaking authority to the relevant executive entity. See, e.g., Solid Waste Agency v. U.S. Army Corps of Eng'rs, 531 U.S. 159, 172-74 (2001); Edward J. DeBartolo Corp. v. Fla. Gulf Coast Bldg. \& Constr. Trades Council, 485 U.S. 568, 574-75 (1988). 